\title{
Palladio's Architectural Orders: From Practice to Theory
}

by DAVID HEMSOLL

The enduring concept of the orders was fundamental to the perpetuation of the classical tradition, and it is central to much architectural theory. One of the most resoundingly influential of its elucidations was published in 1570 by Andrea Palladio (1508-80) in the opening book of his architectural treatise, the Quattro libri dell'architettura (Four Books of Architecture). ${ }^{1}$ There, as in other theoretical works from around this period and later, the five orders - Tuscan, Doric, Ionic, Corinthian and Composite - are presented as a hierarchy of purportedly ideal exemplars; and, in this particular case, their universal 'principles' (precetti) are conveyed through two sets of illustrations, one depicting colonnades (Fig. 1) and the other arcades (Fig. 2), together with many further plates showing various individual details. ${ }^{2}$ In each of the main illustrations, the specimen is given its own designated proportions of column-diameter to column-height, ranging from 1:7 for Tuscan to 1:10 for Composite, and a distinctive formal make-up for both the column and its accompanying entablature. What is little borne in mind, however, is that this published rendition of the orders dates from towards the end of Palladio's career and was preceded by three decades of prolific practice, ${ }^{3}$ during which time his approach - as we shall discover - was in many respects very similar. In other words, the Quattro libri treatment of the orders was not merely a necessary and predictable inclusion in such a publication, or just a theoretical or 'paper' exercise, which is rather how it has also been viewed, ${ }^{4}$ since, as we shall see, it was representative to a very substantial degree of Palladio's actual established practice and its underlying rationale and philosophy.

Palladio's career spanned a period of time that saw major developments in the thinking about the architectural orders. ${ }^{5}$ His first works were informed, as it will become clear, by earlier practice, and especially by the orders as conceived by his elder contemporaries in both Rome and northern Italy. These had departed radically from the positions of yet earlier figures, such as the fifteenth-century theorist Leon Battista Alberti (whose architectural treatise was first printed in 1550 ), ${ }^{6}$ and they had considerably elaborated on the scattered coverage of the orders in Vitruvius. The extent and nature of this dependency on Palladio's part, however, has not previously been established, and nor, for that matter, has the relationship between Palladio's early approach towards the orders and his burgeoning knowledge of the architecture of classical Antiquity. At this 
Fig. 1. Palladio's orders shown as colonnades (I quattro libri, Book 1 , pp. 17, 23, 29, 38 and 45)
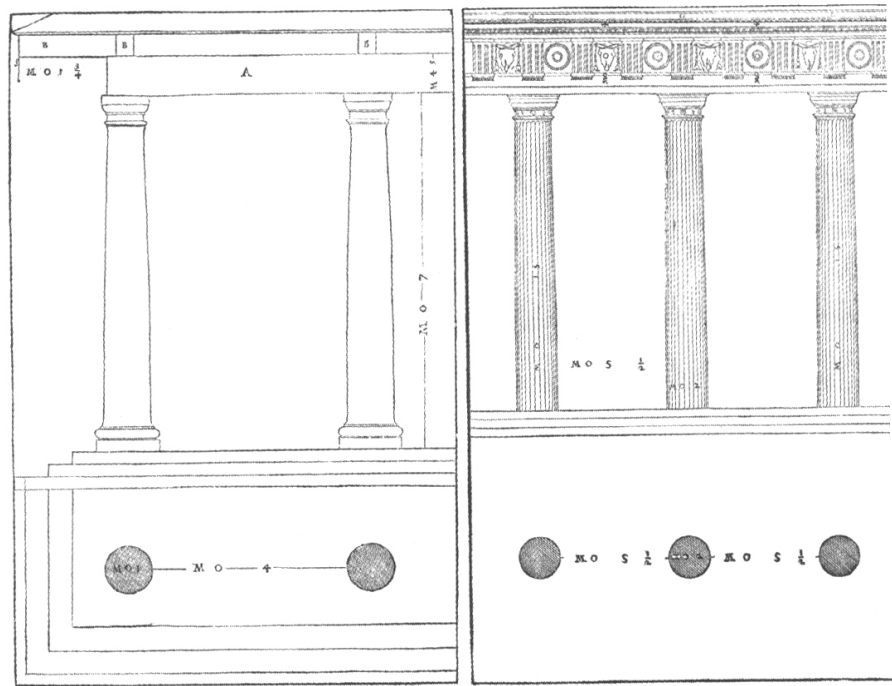

Fig. 2. Palladio's orders shown as arcades (I quattro libri, Book 1,pp.18, $24,30,39$ and 46 )
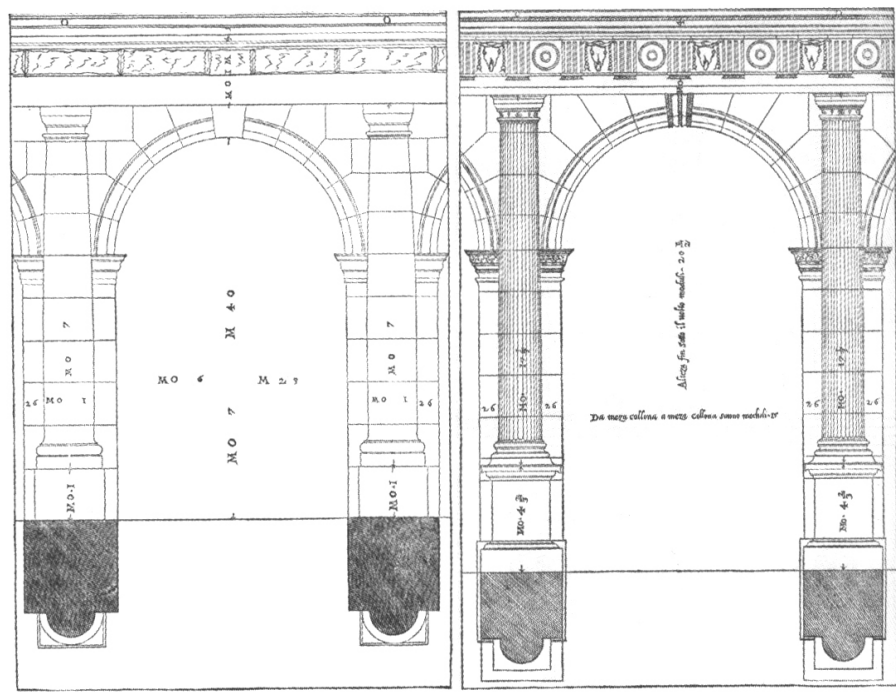

early stage, too, Palladio would have been well aware of many theoretical preoccupations of the time, of the kind aired by Sebastiano Serlio (1475-c. 1554) in his pioneering treatment of the orders (see Table 1), which forms the subject of Book Four of his treatise, published in $1537 ;{ }^{7}$ but Palladio may not, at this juncture, have been overly concerned by the inherently reductive treatment of the subject in such a publication, in fixing upon certain preferred options while excluding many other possibilities. This, however, was set to change when he set his own mind at a similar task, and after the same kind of approach towards the orders had been emphatically taken up in the treatise (1562) published by Jacopo Barozzi da Vignola (1507-73), ${ }^{8}$ which appears to have played an 

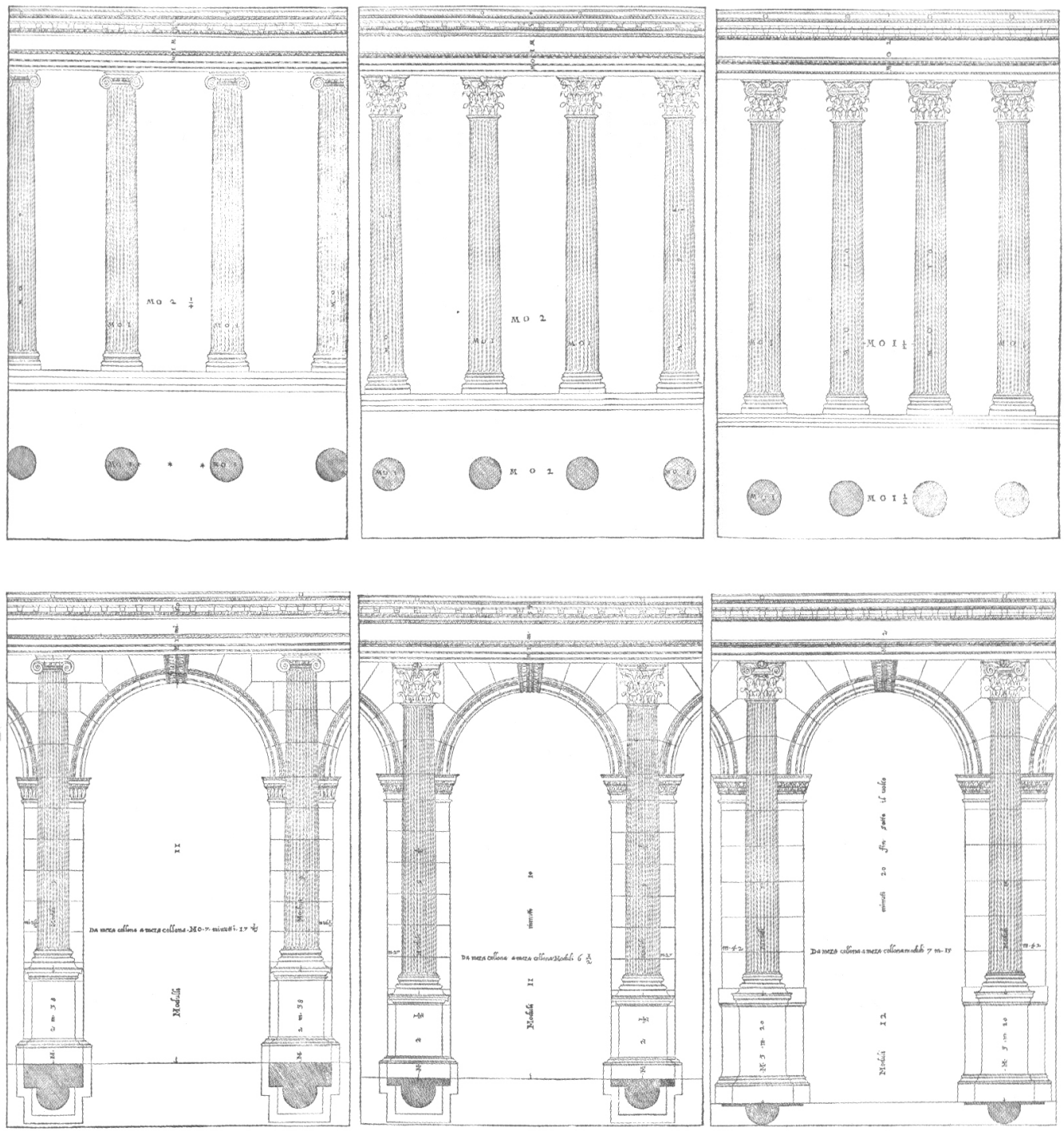

important role in Palladio's theoretical conception of the subject, as well as in the expanded treatise (1567) of Pietro Cataneo (c.1510-c.1574), a figure who, like Vignola, is specifically mentioned in the Quattro libri. ${ }^{9}$ Palladio, in eventually deciding to take such a lead, thus had to find a way of devising specimens of the orders, as will be described, in such a way as to conform with the expectations of such a theoretical conception while, at the same time, managing to encapsulate various key aspects of his own tried and tested modus operandi.

In order to arrive at an understanding of the approach Palladio followed in his practice, information has to be gathered from a wide range of his built schemes, and this 
needs to include reliable measurements of the orders. Fortunately, these can be gleaned from the detailed measured surveys of his buildings undertaken in the eighteenth century by Ottavio Bertotti Scamozzi (1719-90) for his magisterial four-volume publication (1776-83) on Palladio's buildings and designs..$^{10}$ Bertotti Scamozzi's work is invaluable not only because it encompasses almost all of Palladio's built corpus but also because the engraved illustrations record his schemes with such precision, and these provide numerous key dimensions, measured to fractions of an inch, which Bertotti sometimes then compared with the more wayward dimensions that Palladio gave for the same schemes in Books Two and Three of his Quattro libri. ${ }^{11}$ As a result of this, it is fairly easy to amass reliable data on the proportions of the orders employed on many of Palladio's executed works (see Table 2), as well as also analysing their varying formal compositions. It is on this basis that it then becomes possible to identify various changes in Palladio's conception of the orders from his earliest works through to those from the time of Quattro libri and beyond.

What follows, first, will be a comprehensive analysis - not previously attempted of Palladio's various versions of the five different orders. The analysis will be directed, predominantly, at his executed works, with each of the individual orders being examined in turn, although it will also cover the much narrower range of material featured in the Quattro libri. This, in each case, will be considered first, thereby enabling theory to be distinguished from practice and the two to be compared. Particular attention will be given, in both theory and practice, to the proportions of the orders and to the types of capital, base and entablature that were chosen, observing key differences from the formulations of earlier treatise writers, and likely resonances, of the kind that Palladio would have acknowledged, with antique precedent. The results will thus provide some insight into his reliance on antique example, which in the Quattro libri he claims was paramount, ${ }^{12}$ as well as on the treatise of Vitruvius (Palladio's 'master and guide'), ${ }^{13}$ a text Palladio knew extremely well, having produced many of the illustrations for the annotated edition of it published by Daniele Barbaro in $1556 .{ }^{14} \mathrm{It}$ will, however, also become clear that Palladio - especially in his practice - tended to view each individual order not (like, say, Serlio) as being essentially different from the others in its formal constitution, but instead as being in many respects comparable. The article will then explore Palladio's approach towards the orders in relation to those of other leading architects of the early to mid-sixteenth century, and it will sketch out the trajectory of his evolving conception of them, from the outset of his career in around 1540 until the moment they were codified in the Quattro libri. On the basis of these findings, the study will conclude with some concomitant consideration of the Quattro libri orders, examining especially how Palladio dealt with the challenges posed by their necessarily reductive presentation, and also how closely his published orders relate to those seen in the versions of his own schemes that are included in the treatise.

\section{PALLADIO'S TUSCAN ORDER}

The Tuscan order, as presented in the Quattro libri, has the proportions specified by Vitruvius, ${ }^{15}$ and reiterated by Vignola, of 1:7 (Table 1); and it has a formal constitution, in the first of the two main plates (see Fig. 1), that is largely dependent not on observable 


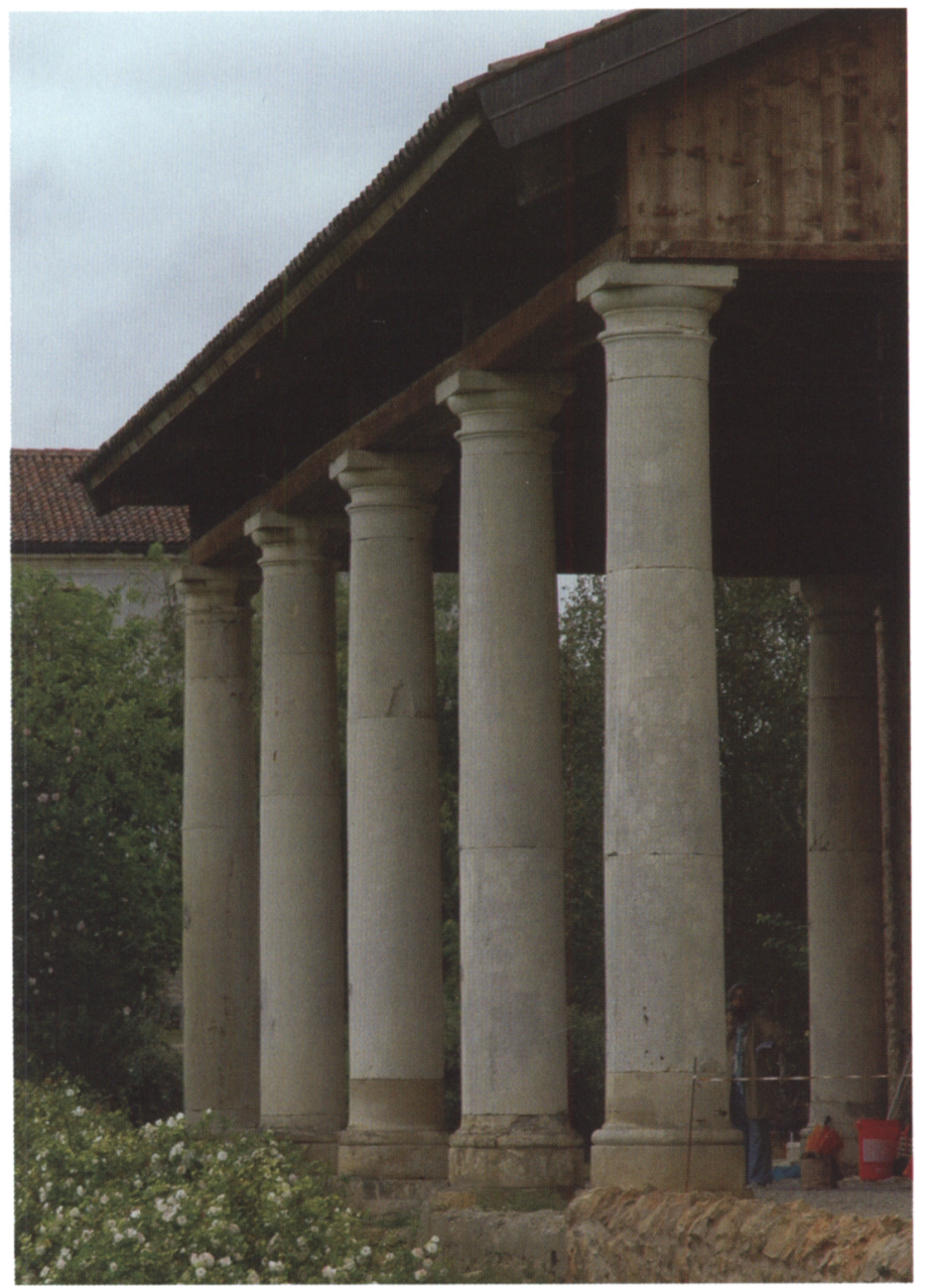

Fig. 3. Palladio's Tuscan order: eastern barn of Villa Trissino, Meledo

ancient practice but on theoretical criteria. This formulation broadly matches with the prevailing consensus established beforehand by Serlio and other theorists, ${ }^{16}$ and it also accords closely with the illustrations of the order that Palladio himself had produced previously for the Barbaro Vitruvius. ${ }^{17}$ As in these earlier illustrations, and in line with Vitruvius's description, the capital is a very simple one (a plain abacus above an echinus with a single ring and then a neck beneath it), the base consists of a single torus supported on a circular plinth, a feature Vitruvius had specified, while the shaft is unfluted, and the entablature is equally rudimentary. However, in the second of the Quattro libri's main plates (see Fig. 2), as well as in one of the plates of details, Palladio departed from this orthodoxy by supplying a whole range of variations that include a capital with an S-profiled echinus, an S-profiled base, a rusticated frieze and a more elaborate cornice made up of a succession of differently shaped mouldings. For this, he 
Fig. 4. Doric order of the Theatre of Marcellus (Desgodetz, Les Édifices antiques, p. 295). The cornice is shown in an unrestored state.

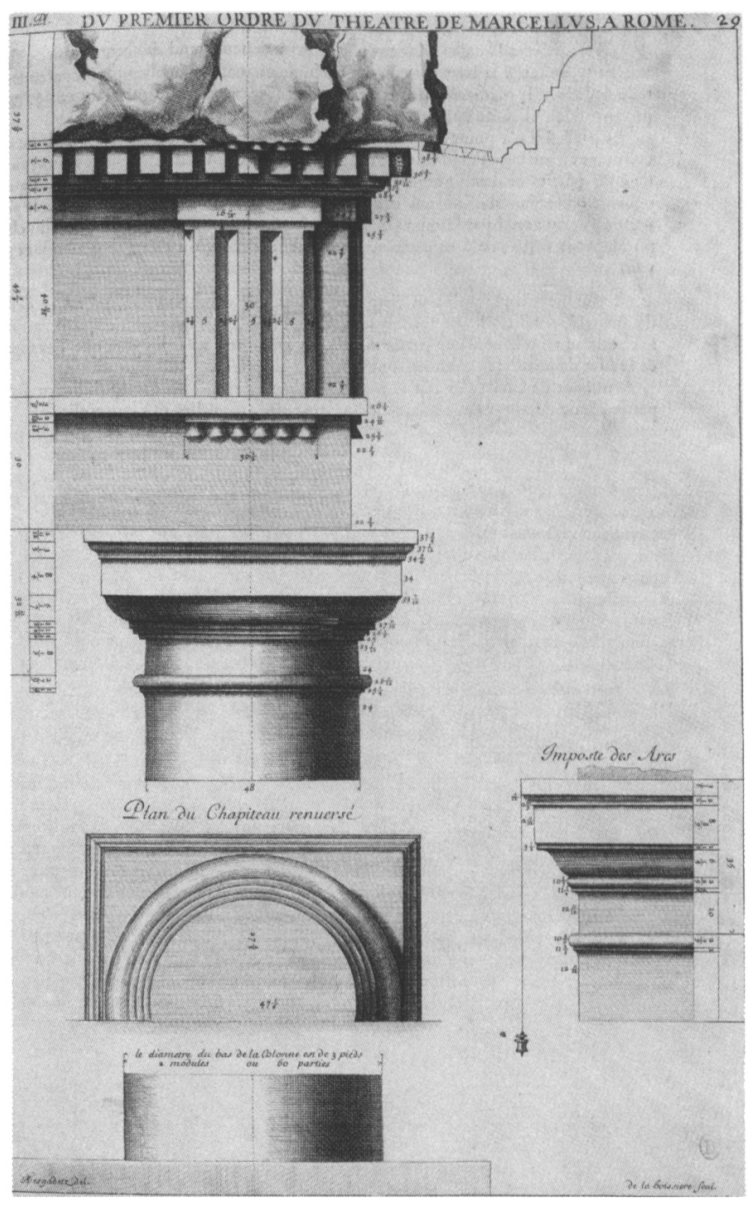

very possibly took a cue from Serlio who had added some additional elements to the entablature for those architects who required 'more delicate' work; ${ }^{18}$ and he was perhaps recognising, too, that there had been considerable disagreement, earlier in the sixteenth century, over the order's precise form. ${ }^{19}$ Palladio's variations, however, all find close parallels in the orders that were used for the ancient amphitheatres of Verona and Pula, which had previously been illustrated by Serlio, ${ }^{20}$ and which Palladio had conveniently declared, in the accompanying Quattro libri commentary, to be Tuscan, even though their proportions are much more attenuated. ${ }^{21}$ This variant version of the Tuscan order is also more closely comparable to the formulations of Palladio's other orders.

In his executed work, Palladio's employment of the Tuscan order was extremely limited. His only certain usage of it was for the barns (Fig. 3) of the largely unrealised Villa Trissino at Meledo (1553), which have columns described in the Quattro libri as Tuscan, and which are closely comparable to the specimens presented in the first of the Quattro libri plates, albeit with proportions of around $1: 7^{1 / 2}$ rather than $1: 7 .{ }^{22}$ It is just 


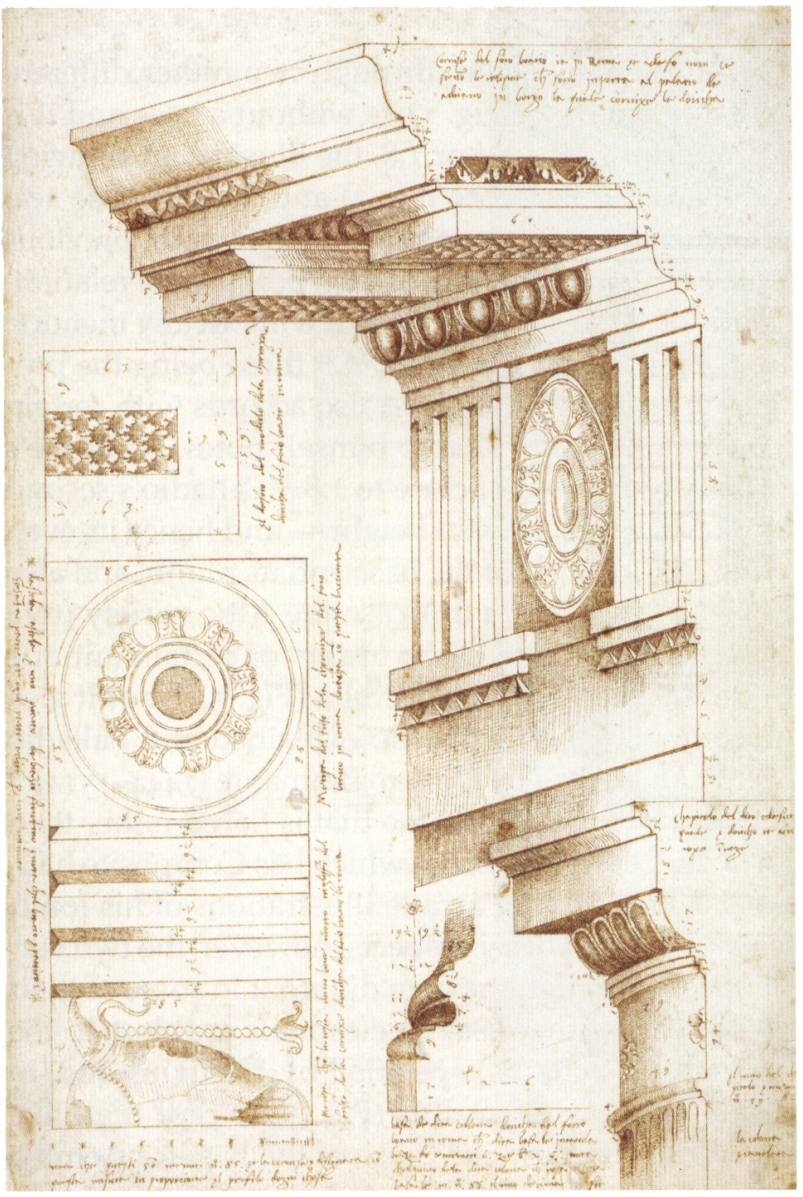

Fig. 5. Palladio, Doric order of the Basilica Aemilia (Vicenza, Palladio Museum, D 5v). With permission from the Comune and the Palladio Museum, Vicenza

possible that the very simple pilaster order of the executed barn at Villa Thiene at Cicogna (1556), which has an unadorned frieze, was regarded by some of Palladio's contemporaries as Tuscan, considering that there had been such little agreement, early on in the century, over the order's correct form, ${ }^{23}$ but Palladio is much more likely to have viewed it as Doric, since it is akin to his conception of that order both in its proportions, which are of around 1:8 (see Table 2), and - apart from the plain frieze - in its formal configuration. He may well, however, have been intentionally alluding to the Tuscan order in certain examples of his Doric that have distinctly Tuscan characteristics. He employed, for example, a circular plinth for the minor Doric (and Ionic) order of his Basilica in Vicenza (1546-49) (see Fig. 7); a single-torus base for the columns in the androne of Palazzo Thiene in Vicenza (1542) and the vestibule of the conventual complex attached to S. Maria della Carità in Venice (1560); and a capital with an S-shaped echinus for the exceptionally sturdy interior columns of the Loggia del Capitaniato in Vicenza (1565) (see Fig. 6). ${ }^{24}$ 


\section{PALLADIO'S DORIC ORDER}

In the Quattro libri, the Doric order is represented, again, through two rather different exemplars. The first, seen in the colonnade plate (see Fig. 1), is without a base and it is described as having the more bulky proportions of $1: 7^{1 / 2}$ or $1: 8$, the illustration showing the former. The second is shown in the arcade plate (see Fig. 2) and it has a base and proportions this time of $1: 82 / 3$. Neither of these formulations tallies with those of previous theorists (Table 1 ), ${ }^{25}$ and neither is explained; but the first specimen bears some relationship to Vitruvius's discussion of the Doric order, which describes it without any mention of a base, and as having proportions of $1: 7$ or, alternatively, $1: 7^{1 / 2},{ }^{26}$ these being the proportions of the baseless columns illustrated. The baseless type also accords with certain ancient examples of the order, such as that seen, as Palladio himself notes, on Rome's Theatre of Marcellus (Fig. 4), ${ }^{27}$ which has proportions of close to $1: 8{ }^{28}$ Palladio's second exemplar, which has proportions of $1: 82 / 3$, achieves its extra height - and hence its even more attenuated proportions - through the addition of the base and its plinth, and also the flare at the bottom of the shaft. ${ }^{29}$ Having a base, in this case the Attic variety (two toruses with an intervening scotia), accords with the Doric orders of certain antique monuments such as Rome's by-then demolished Basilica Aemilia (Fig. 5), ${ }^{30}$ but it also followed well established modern precedent, which, as Serlio explained and Palladio would doubtless have known, had been inaugurated by Donato Bramante (1444-1514). ${ }^{31}$ The plinth chosen by Palladio is distinctive in having a profile that is flared rather than flat-faced, like those of the ancient Porta dei Leoni in Verona (which has Composite halfcolumns), ${ }^{32}$ and it is of the same type also used for the arcade illustrations of his Ionic, Corinthian and Composite orders (see Fig. 2). In all other respects, however, the two versions of Palladio's Doric order are identical, although they are different in some of their details from those of Serlio and the other earlier theorists. The capitals are close to the type (with three rings and a neck beneath the echinus) specified by Vitruvius and, in particular, the model provided by the Theatre of Marcellus (Fig. 4), except that, like Vignola's, they have necks ornamented with rosettes, like those of the Basilica Aemilia (Fig. 5). ${ }^{33}$ The shafts follow the recommendations of Vitruvius and previous theorists in having distinctively Doric flutes, twenty in number and each abutting its neighbour at an arras. ${ }^{34}$ The entablature accords broadly with Vitruvius's prescription, ${ }^{35}$ and it includes an architrave with a pair of fascias (albeit not just one, as stipulated by Vitruvius and featured in Serlio's and Vignola's illustrations), and a frieze embellished with triglyphs and metopes ornamented with paterae and bulls' heads, like that of the Basilica Aemilia. The cornice lacks a row of characteristic blocks - or mutules (in the correct sense of the term) - despite this being a frequent feature of ancient buildings (including the Basilica Aemilia: see Fig. 5) ${ }^{36}$ and, as Palladio himself notes, it is more elaborate than the one specified by Vitruvius - and the one recommended by Vignola - in having an additional cavetto and ovolo beneath the overhang of the corona ${ }^{37}$ In its greater complexity, it also corresponds, therefore, to the cornices of the other orders illustrated subsequently.

The proportions Palladio chose for the Doric order in his practice are often incompatible with those specified in the Quattro libri, and their range is even greater (Table 2). This spread, as well as deriving some support from the range of ratios specified or implied by Vitruvius, is also broadly consistent with the considerable variation in the proportions of the Doric order seen in ancient architecture, as Palladio himself must 
Fig. 6. Palladio's Doric order: interior of the Loggia del

Capitaniato, Vicenza

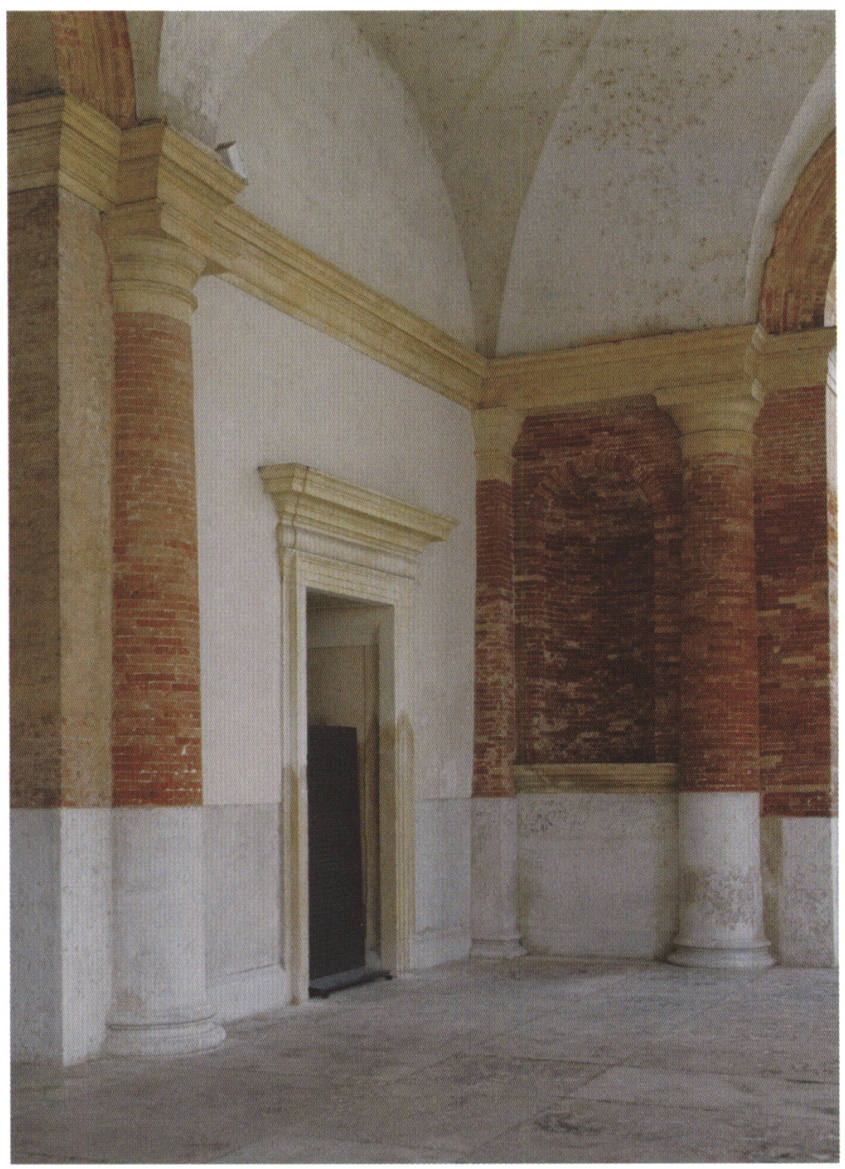

surely have recognised.$^{38}$ It tallies too with a theoretical principle that is implied in the Quattro libri, and explicitly set out by Serlio and illustrated by him, significantly in this context, with examples specifically of the Doric order. ${ }^{39}$ This is that the order's proportions should depend on its usage, with load-bearing and free-standing columns being the most sturdy, and those applied to arcades or other surfaces 'more for ornament than for support' being more attenuated. ${ }^{40}$ Thus Palladio seems to have preferred sturdy proportions for free-standing columns which include examples without bases such as those in the androne (entrance hall) of Villa Pisani at Montagnana (1552) which have proportions of just over 1:7, and also include examples that have bases, such as those used for the vaulted interior of the Loggia del Capitaniato (Fig. 6), which are even more bulky and have proportions of below 1:7. ${ }^{41}$ More slender proportions tend to be reserved for applied orders that have bases, and these rise well beyond the Quattro libri's stipulated ratio of $1: 823$, to reach around $1: 9$ for the pilasters adorning the portico (and interior) of the early Villa Pisani at Bagnolo (1542) and those on the exterior of the early Villa Thiene at Quinto (c.1542), and thus straying well into the range associated in the Quattro libri with the Ionic order. Most of the examples provided with bases have proportions that 


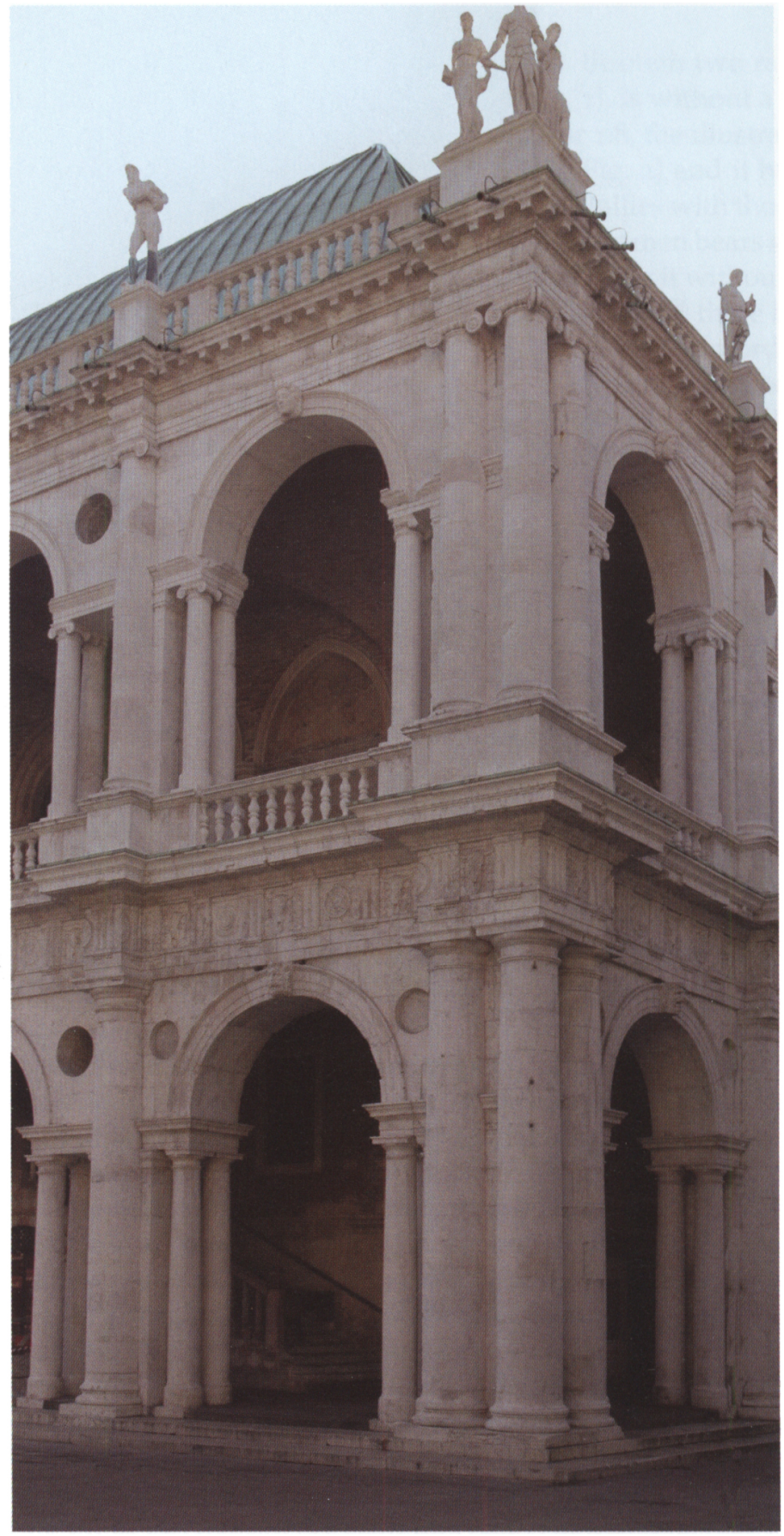

Fig. 7. Palladio's Doric and Ionic orders: arcades (northwest corner) of the Basilica, Vicenza 


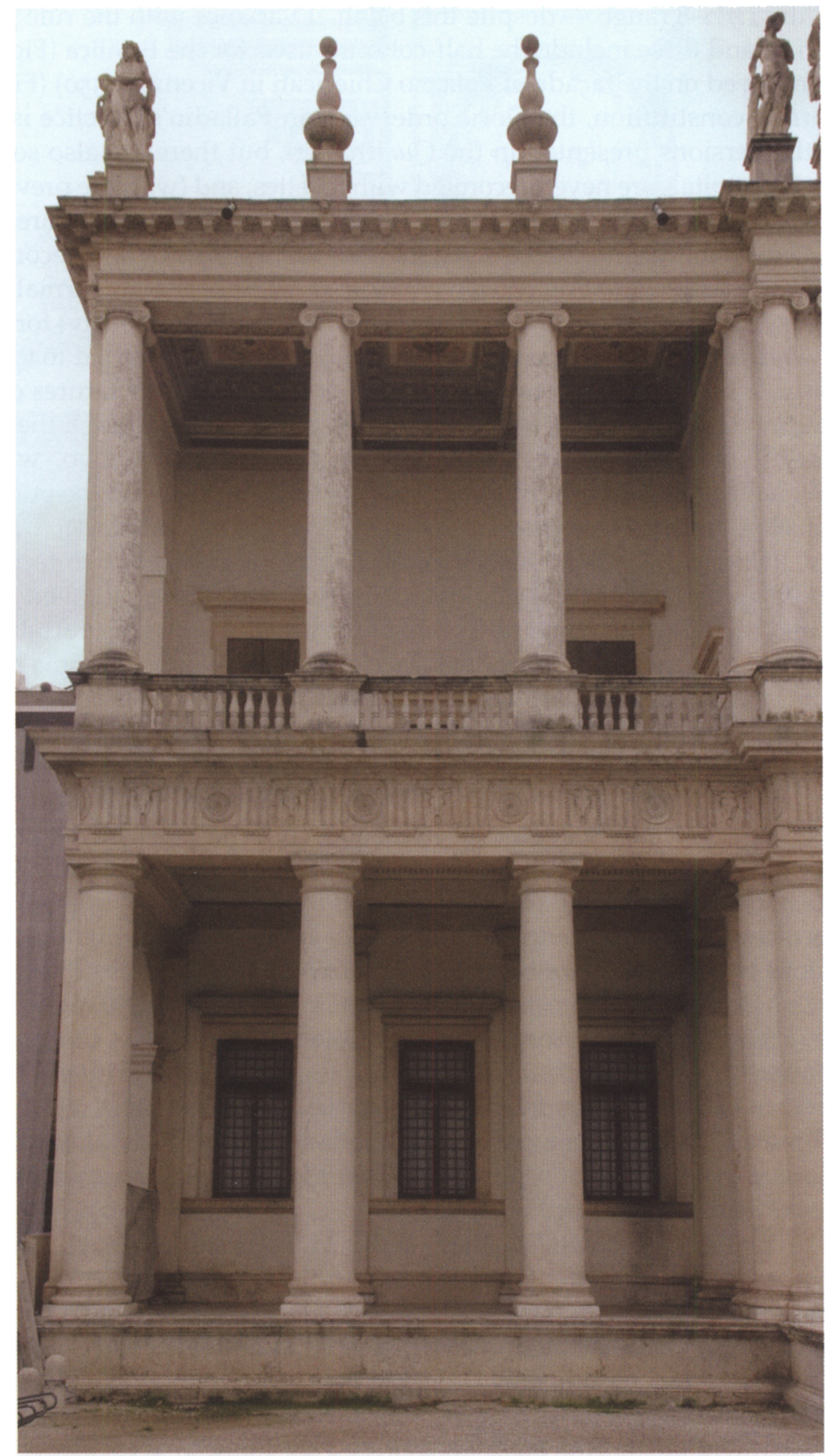

Fig. 8. Palladio's Doric and Ionic orders: façade (first-executed southern portion) of Palazzo Chiericati, Vicenza 
fall within the $1: 7^{1 / 2}-8$ range - despite this being at variance with the rule given in the Quattro libri - and these include the half-columns used for the Basilica (Fig. 7) and the columns employed on the façade of Palazzo Chiericati in Vicenza (1550) (Fig. 8). ${ }^{42}$

In its formal constitution, the Doric order seen in Palladio's practice is often very similar to the versions presented in the Quattro libri, but there are also some notable deviations. His capitals are never decorated with rosettes, and (with the previously mentioned exception of the interior order of the Loggia del Capitaniato) they are of the same plain variety used for the Theatre of Marcellus (see Fig. 4), ${ }^{43}$ which had become standard in contemporary practice. ${ }^{44}$ When he gave the order a base, Palladio normally chose the Attic type (as shown in the Quattro libri), although (as noted previously) for the androne of Palazzo Thiene and the vestibule of S. Maria della Carità he resorted to the type with a single-torus, while his shafts are almost never fluted..$^{45}$ His entablatures can often be very similar to the examples he illustrates in the Quattro libri, although the architraves sometimes follow Vitruvius by having one fascia rather than two, while friezes occasionally have their triglyphs omitted, as is notably the case with the portico of Villa Emo at Fanzolo (c. 1555), as well as with the barn of Villa Thiene at Cicogna. In a number of instances, Palladio omitted the frieze entirely (as several previous architects had done) on the model of the ancient Crypta Balbi. ${ }^{46}$ In this regard, he followed the ancient prototype and included the guttae at the top of the architrave for the portal of the early Casa Civena in Vicenza (1540) and the entrance serliana of Villa Valmarana at Vigardolo (1542); ${ }^{47}$ but later, as in the cases of the androni of Palazzo Thiene and Villa Pisani at Montagnana, the minor Doric order of the Basilica (Fig. 7) and the interior of the Loggia del Capitaniato (Fig. 6), these were usually dispensed with. ${ }^{48}$ The cornices, like in the Quattro libri illustration, never have mutules (i.e. blocks beneath the corona), although they do not follow precisely the same formal sequence. In the cases of Palazzo Chiericati (Fig. 8) and Villa Emo, they include unadorned and overhanging slabs beneath the corona, like in the cornice of the Doric storey (and the two above it) of the Colosseum, ${ }^{49}$ and the cornices Palladio sometimes designed for other orders, while the final cima is often replaced by a cavetto (as seen in the Theatre of Marcellus; see Fig. 4). A typical example of his Doric entablature is that of the Basilica (Fig. 7), and this is identical to the Quattro libri illustration apart from a couple of minor discrepancies in the cornice (the cima versa switched with the cavetto). An unusually wayward entablature is the one seen in the courtyard of the S. Maria della Carità complex where the frieze is decorated with swags and paterae, ${ }^{50}$ and then surmounted by a band of dentils, in a manner recalling the Doric order of the Theatre of Marcellus (see Fig. 4) as well as numerous ancient examples of the Ionic order (see Fig. 9)..$^{51}$

\section{PALLADIO'S IONIC ORDER}

In the Quattro libri plates, the Ionic order is relatively standardised. It is allocated the proportions of 1:9, which is in line with Vitruvius's preferred specification (although he also prescribed $1: 8 \frac{1}{2}$ ), ${ }^{52}$ as well as with Vignola's recommendation (Table 1 ). The formal sequence illustrated in the two main plates (see Figs 1 and 2) is identical, although it again differs in certain particulars from those of earlier theorists. ${ }^{53}$ The capital is of a type with no neck, ${ }^{54}$ with its echinus ornamented with egg and dart and with sprays of foliage 

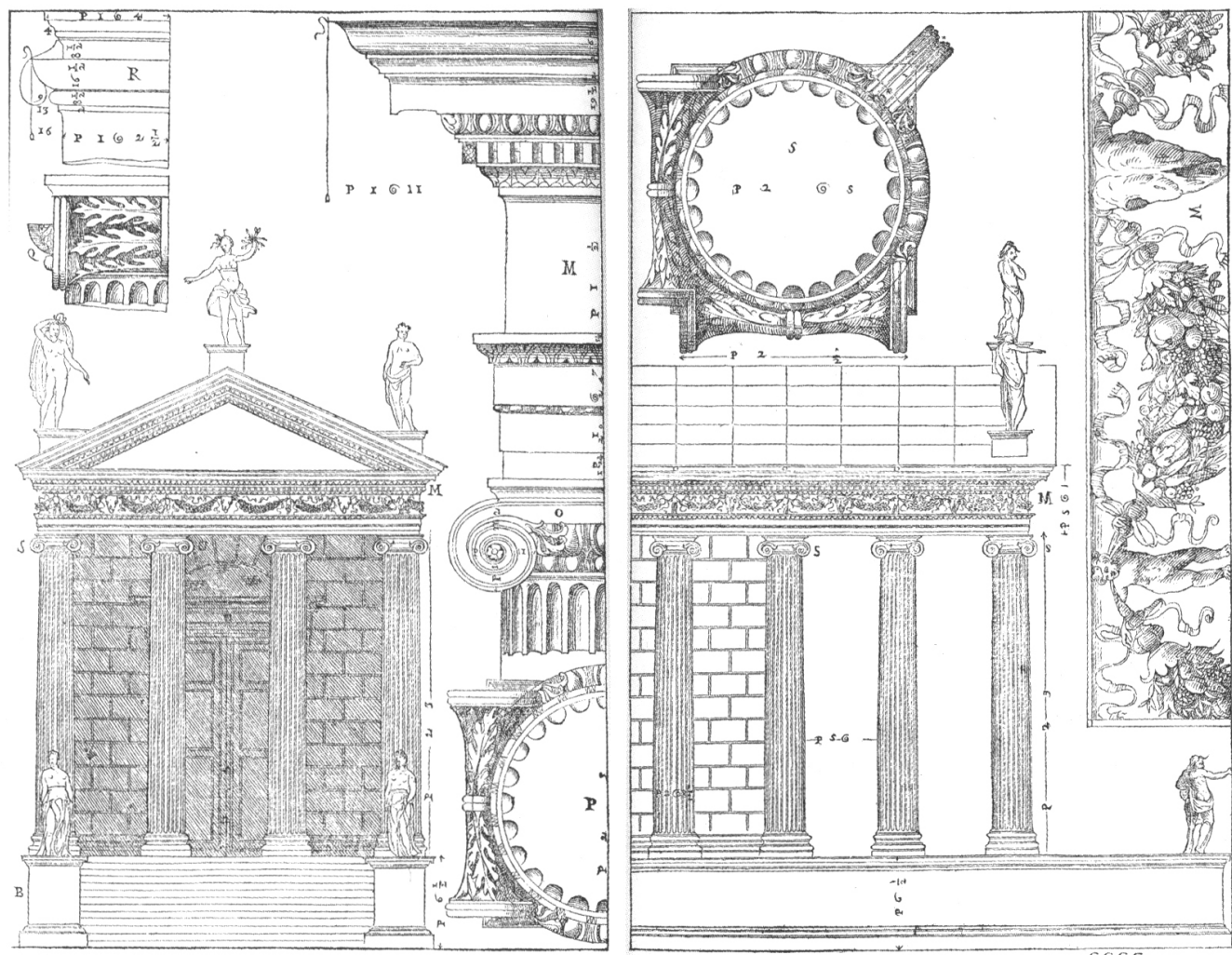

Fig. 9. Ionic order of the Temple of Portumnus (I quattro libri, Book 4, pp. 50-51)

emerging from the insides of the volutes, a type previously illustrated by both Serlio and Vignola, ${ }^{55}$ and featured on the Theatre of Marcellus and the Temple of Portumnus ('Fortuna Virilis') in Rome, which is illustrated in Book Four of the Quattro libri (Fig. 9). ${ }^{56}$ The base shown in the main plates is, again, of the Attic type but, like certain previous authors, Palladio also followed Vitruvius by supplying an alternative, included in a plate of details, that has a torus above a pair of scotias separated by twin astragals, which, as he implies, was unknown from any extant antique example; ${ }^{.57}$ and the shaft is again fluted. The entablature has an architrave with three fascias, as Vitruvius had described, which is surmounted (as is clear from a plate of details) by a frieze that is pulvinated (i.e. bulging), an option recommended previously by Serlio and also illustrated by Palladio in the Barbaro edition of Vitruvius. ${ }^{58}$ Such conformity with established precedent, however, makes the unusual treatment of the cornice especially surprising. This lacks the band of dentils, in contradiction both of previous treatise writers and of Vitruvius, whose specifications Palladio had previously followed in his plate for Barbaro's edition. ${ }^{59}$ The absence of dentils is also an abrupt departure from ancient practice, as represented by the Theatre of Marcellus and the Temple of Portumnus (Fig. 9), and from much modern precedent too. The cornice, instead, has a cavetto and ovolo, 
recalling the equivalent plates showing the Doric order, followed by a row of modillions, or brackets, beneath the corona (like in the subsequent plate showing the Corinthian cornice), which are not mentioned by Vitruvius, and rarely featured in ancient Ionic buildings ${ }^{60}$ It seems very possible, therefore, that Palladio's avoidance of dentils was, in part, connected with his inclusion of modillions, and that it was to an extent determined by a theoretical concern, which, as Serlio had explained, was that dentils should not be used in combination with modillions, for the reason that both of them represented the ends of beams. ${ }^{61}$ Palladio's theoretical formulation in the Quattro libri accorded, too, with several examples of the Ionic cornice that have modillions, but not dentils, in various previously executed works (see Figs 7,8 and 10-12). As for the modillions themselves, these are shown in one of the plates of details to be block-like in shape but with undulating lower surfaces, like those girding the drum of Rome's Pantheon, and those of its Ionic but highly unorthodox Temple of Saturn..$^{62}$

The proportions that Palladio chose for the Ionic order in his practice (Table 2) are reasonably consistent (despite a couple of obvious anomalies) ${ }^{63}$ with the 1:9 ratio given in the Quattro libri. Some relatively early examples, such as the main upper order of the Basilica (Fig. 7), however, tend to be a little less slender, and the variation is noticeably great. Where there are significant departures, these can perhaps be sometimes related to particular kinds of usage. Thus, the storey-supporting order of Palazzo Valmarana in Vicenza (1565) (Fig. 12) is notably broad in proportion, as is the vault-supporting order in the androne of Palazzo Barbaran in Vicenza (1569). However, there is no consistent differentiation between free-standing and applied orders. The applied half-columns of Palazzo Antonini at Udine (c.1556) and the free-standing columns of Villa Sarego at S. Sofia (1565), which are both sheathed by rustication, are especially slender, but so are the half-columns used for Villa Barbaro at Maser (c.1554) and the portico columns of Villa Badoer at Fratta Polesine (c.1555), and all these have proportions that are slimmer than those Palladio prescribed for the Corinthian order.

The examples of the Ionic order employed in Palladio's practice also conform quite closely, in their formal composition, to the specifications of the treatise. Thus, his capitals are almost always close in their basic design to the Portumnus type that he illustrated there (Fig. 9), although for the minor order of the Basilica they are given short necks, and the amount of ornamentation often differs. The ornamentation is nearly as rich in the cases of the early Palazzo Porto Festa in Vicenza (c. 1546), the Basilica (Fig. 7) and Palazzo Chiericati (Fig. 8) but more usually, as in the cases of Villa Rotunda outside Vicenza (1566/67) and many other works (see Figs 10 and 24), it is almost entirely absent. Palladio also turned to the Temple of Portumnus (Fig. 9) to provide a model for the corner-capitals with abutting scrolls that he used for the external corners of the Basilica (Fig. 7) and Villa Foscari at Malcontenta (1554) (Fig. 10) and the internal angles of the colonnades of Villa Sarego and the courtyard of Palazzo Barbaran (Fig. 11). ${ }^{64}$ For the capitals of the window tabernacles of Palazzo Thiene (see Fig. 20) and the androne columns of Palazzo Barbaran, however, he utilised a rather different variety, with canted volutes at the corners instead of a pair of scrolls. ${ }^{65}$ As regards bases, he never employed the 'Vitruvian' variety he describes in the treatise, and, instead, he relied almost entirely (for large-scale orders) on the Attic type or, for the courtyard of Palazzo Valmarana and the façade and courtyard of Palazzo Barbaran, on the Attic type with an additional 


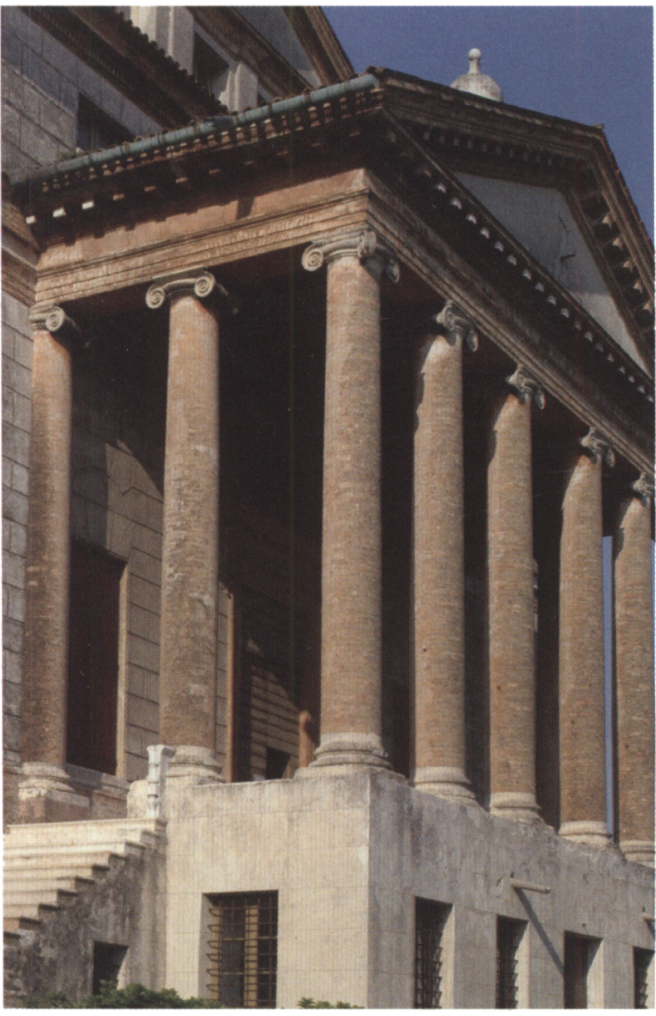

Fig. 10. Palladio's Ionic order: portico of Villa Foscari, Malcontenta

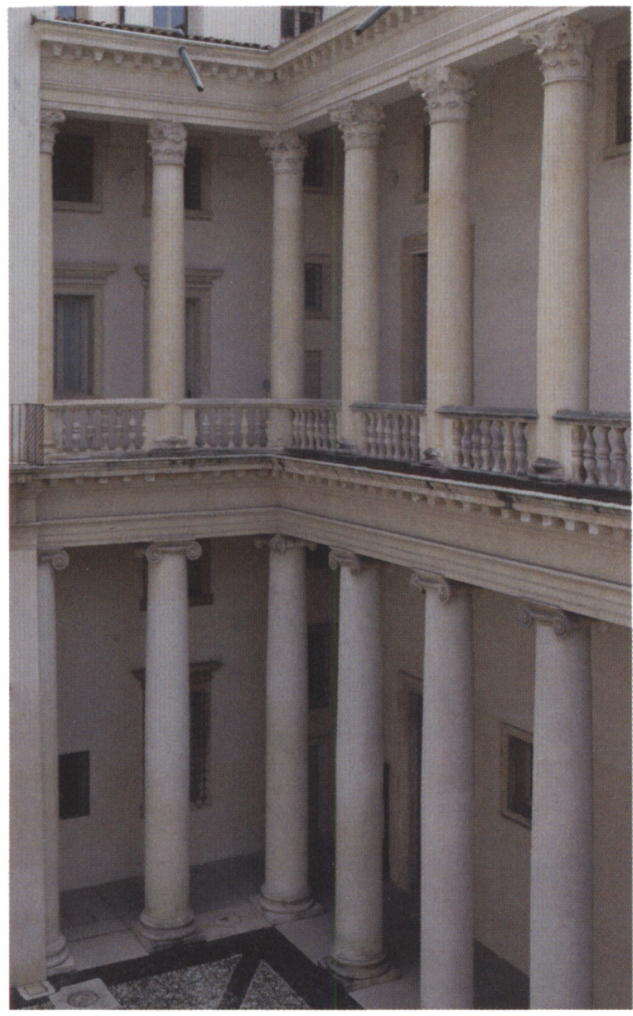

Fig. 11. Palladio's Ionic and Corinthian orders: courtyard corner of Palazzo Barbaran, Vicenza

astragal at the top. ${ }^{66}$ The only exception is the type used for the façade half-columns (see Fig. 24) of Palazzo Porto Festa, which are of similar design to the 'Vitruvian' base, but with an extra pair of astragals at the bottom, like certain examples inspired by ancient precedent and employed previously in Rome. ${ }^{67} \mathrm{He}$ never used fluted shafts, but his entablatures correspond closely with the Quattro libri formulation, a very typical example being that of the Basilica (Fig. 7), which is, again, virtually identical to the one in the treatise. They usually have architraves with three fascias and sometimes, as in the cases of the Basilica and Villa Rotunda (see Fig. 24), a pulvinated frieze followed by a cornice without dentils. A particularly unusual feature of the friezes seen in the courtyards of Palazzo Valmarana (Fig. 12) and Palazzo Della Torre in Verona (c.1555) is the row of blocks positioned above the columns, and this could have been suggested by the surviving colonnade of the northern temple in Rome's Forum Holitorum, which is embedded into the flank of the church of S. Nicola in Carcere and where the ends of the projecting lintels above its Ionic columns are in comparable positions (Fig. 13) ${ }^{68} \mathrm{In}$ respect to his cornices, the precise sequence of mouldings can vary considerably from that shown in the Quattro libri illustrations, and, as in the cases of Palazzo Porto Festa, Palazzo Chiericati (Fig. 8) and Villa Pisani at Montagnana, it often includes (as also in 


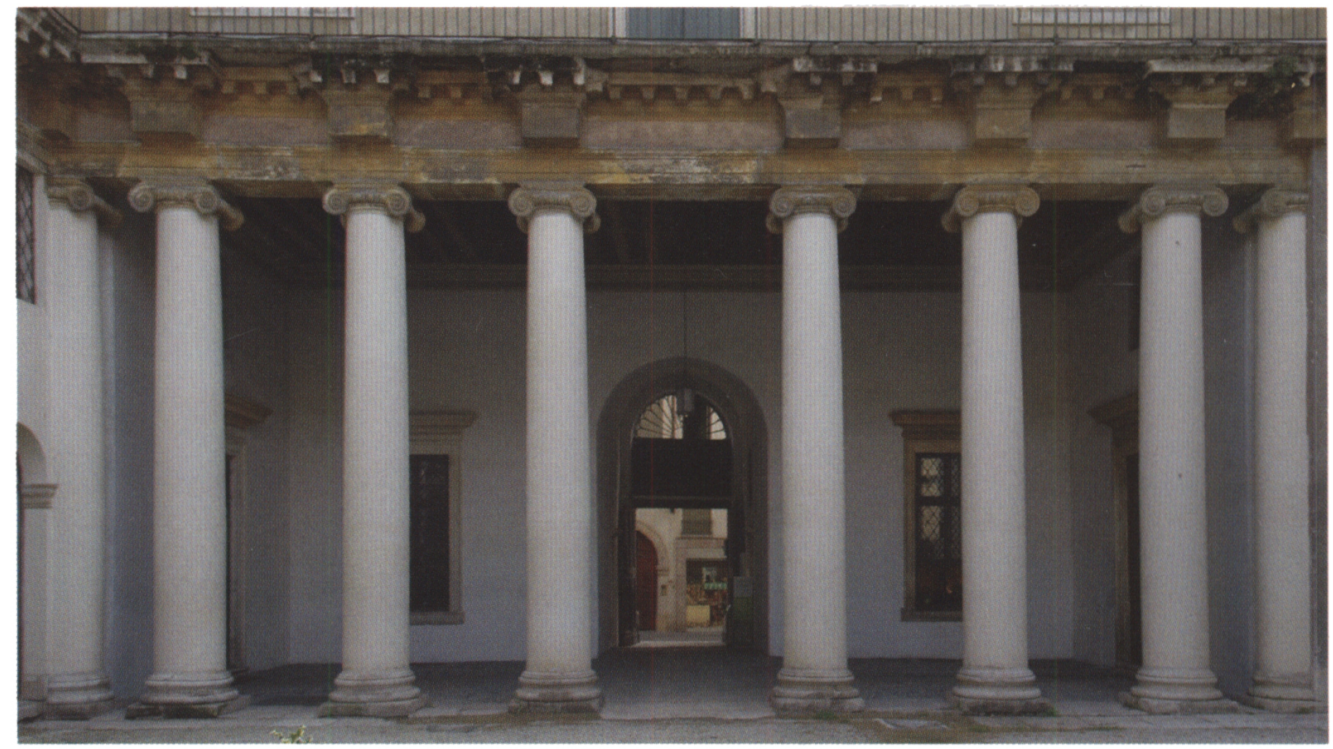

Fig. 12. Palladio's Ionic order: courtyard portico of Palazzo Valmarana, Vicenza

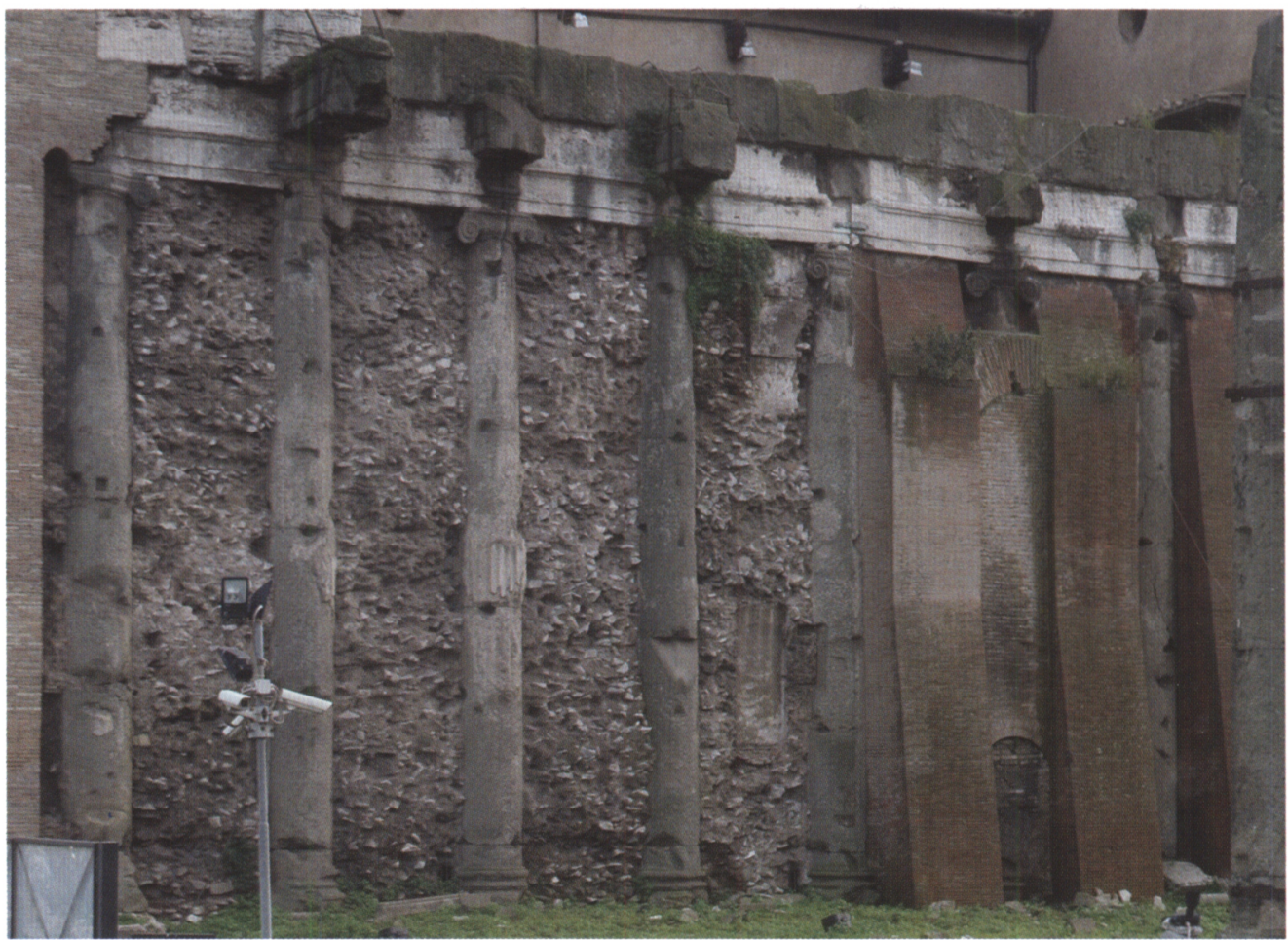

Fig. 13. Rome, S. Nicola in Carcere, northern flank 
Palladio's Corinthian and Composite orders) a plain and overhanging slab in the place of a band of dentils, of the kind seen on the Colosseum and also used for the Pantheon. ${ }^{69}$ Like in the Quattro libri plates, however, there is often a row of modillions beneath the corona, this being especially typical of cornices used for the upper orders of two-storey façades or the giant orders of tall porticoes (Figs 6, 7 and 10). The modillions themselves, employed on the Villa Rotunda and elsewhere (see Figs 24 and 10), are of the same plain type with an undulating lower surface that is represented in the Quattro libri.

\section{PALLADIO'S CORINTHIAN ORDER}

The Corinthian order, in the Quattro libri, is allotted the proportions of $1: 9^{1 / 2}$, and the main illustrations show a very consistent design with almost no variation. The proportions are broadly in line (see Table 1 ) with those implied by Vitruvius (although he discusses the order in very little detail) ${ }^{70}$ and are more slender than those proposed by some of Palladio's predecessors, but not as slender as the 1:10 ratio recommended by Vignola. They are also strikingly out of line with ancient practice, as witnessed by the many ancient examples of the Corinthian order, and especially the portico columns of temples, that Palladio himself illustrated in Book Four, which almost all have the proportions of around 1:10 (Table 3). ${ }^{71}$ The formal makeup of the order again diverges in various ways from those recommended by earlier writers (see Figs 1 and 2)..$^{72}$ The capital is of the same well-established type used, for example, for the ancient Pantheon (rather than being modelled on that of Rome's Temple of Castor which Palladio said he particularly admired) ${ }^{73}$ although its foliage is of a distinctive kind. This is similar to the kind previously illustrated by Vignola ${ }^{74}$ and takes as its model the capitals of Rome's (now-demolished) Temple of Minerva (Fig. 14) which, as Palladio remarked, are carved with 'olive leaves' arranged in fives 'like the fingers of men's hands'. ${ }^{75}$ The base, indicated in the main plates, is not the variety previously depicted by both Serlio and Vignola, the one used for the Pantheon that has a torus above and below two scotias which are separated by a pair of astragals. Instead, it is the variant of the Attic type with an extra astragal above the upper torus, the kind seen in a number of Rome's ancient buildings, including the Temple of Hadrian (Fig. 15), that are illustrated in Book Four. ${ }^{76}$ Also shown in one of the plates of details, however, is a more elaborate alternative, with three extra astragals, which was known from other examples from Rome. ${ }^{77}$ The shaft is once again fluted, while the entablature, as shown in the two main plates, conforms closely with the ones represented by both Serlio and Vignola in having an architrave with three fascias, a plain frieze and a cornice with modillions beneath the corona, the latter combination not mentioned by Vitruvius but frequently seen, as Serlio had observed, in ancient practice. ${ }^{78}$ In Palladio's case, the precise sequence of mouldings, which in the main plates appears to include a cima versa, a plain and overhanging slab and an ovolo beneath richly ornamented modillions, is virtually identical to that of the main internal and external cornices of the Pantheon. ${ }^{79}$ In one of his plates of details, however, the slab is replaced, rather perversely - and like in Vignola's illustrations ${ }^{80}$ -by a band of dentils, for which the closest ancient parallel is provided by the colonnades of the Forum of Nerva, the ancient forecourt laid out to the front of the Temple of Minerva. ${ }^{81}$ 
Fig. 14. Corinthian order of the Temple of Minerva (I quattro libri, Book 4, p. 28)

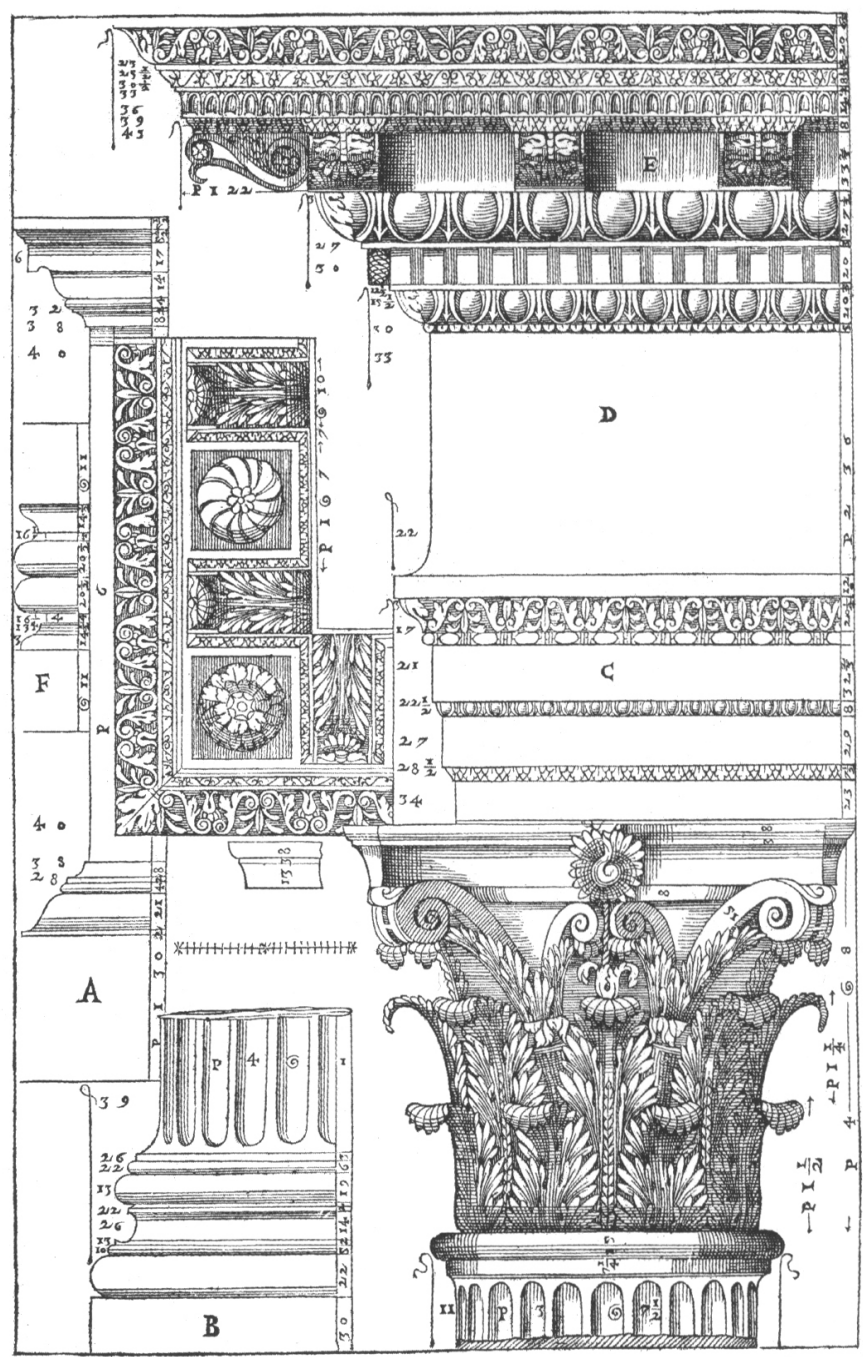

The proportions chosen for the Corinthian order in Palladio's practice - rarely used before around 1560 - corroborate the Quattro libri recommendation of 1:91/2 only to an extent and not with a constancy that would suggest that this was a persistent ideal (Table 2). In some schemes, the order is indeed in the vicinity of $1: 9^{1 / 2}$, and these include the early Casa Civena, which has a façade set out with paired pilasters of a proportion of 'more' than 1:91/2, ${ }^{82}$ and a number of later schemes including Palazzo Valmarana, Palazzo Barbaran and the late Teatro Olimpico in Vicenza (1580), which all date from around or after the time the Quattro libri was being composed. Some works, however, notably the fairly early Villa Cornaro at Piombino Dese (1552), have Corinthian orders with proportions in the region of 1:10, and there are several examples of Corinthian orders with such proportions even from Palladio's later career. They include, for instance, 


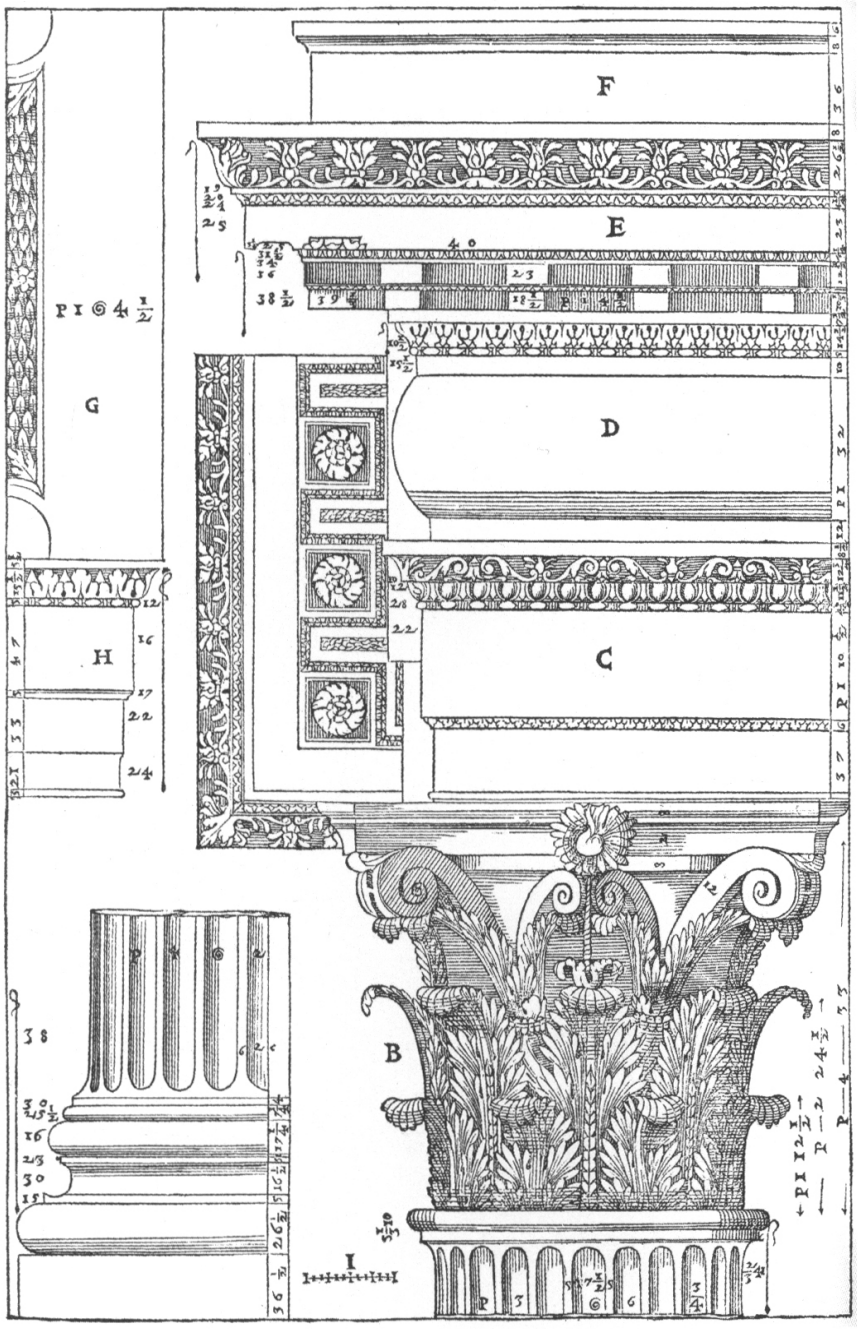

Fig. 15. Corinthian order of the Temple of Hadrian (I quattro libri, Book 4, p.60)

S. Francesco della Vigna (1564), S. Giorgio Maggiore (1565) and the late Redentore (1576), all in Venice, as well as Palazzo Porto Breganze in Vicenza (1571), which has Corinthian columns in the courtyard designed to support an upper storey. In all these works, therefore, the proportions are in line with those stipulated by Palladio for the Composite order.

In its formal composition, the Corinthian order employed by Palladio in his practice departs considerably from the examples illustrated in the Quattro libri. His capitals (e.g. Fig. 16) are, for the most part, of the general kind represented in the treatise, ${ }^{83}$ but they are usually carved much less richly, ${ }^{84}$ or else, as in the case of those inside S. Giorgio Maggiore (Fig. 17) or those previously employed for the façade of the early Casa Civena, they have foliage that is completely plain, like the ancient capitals seen on the third 
Fig. 16. Palladio's Corinthian and Composite orders: façade of the Redentore, Venice

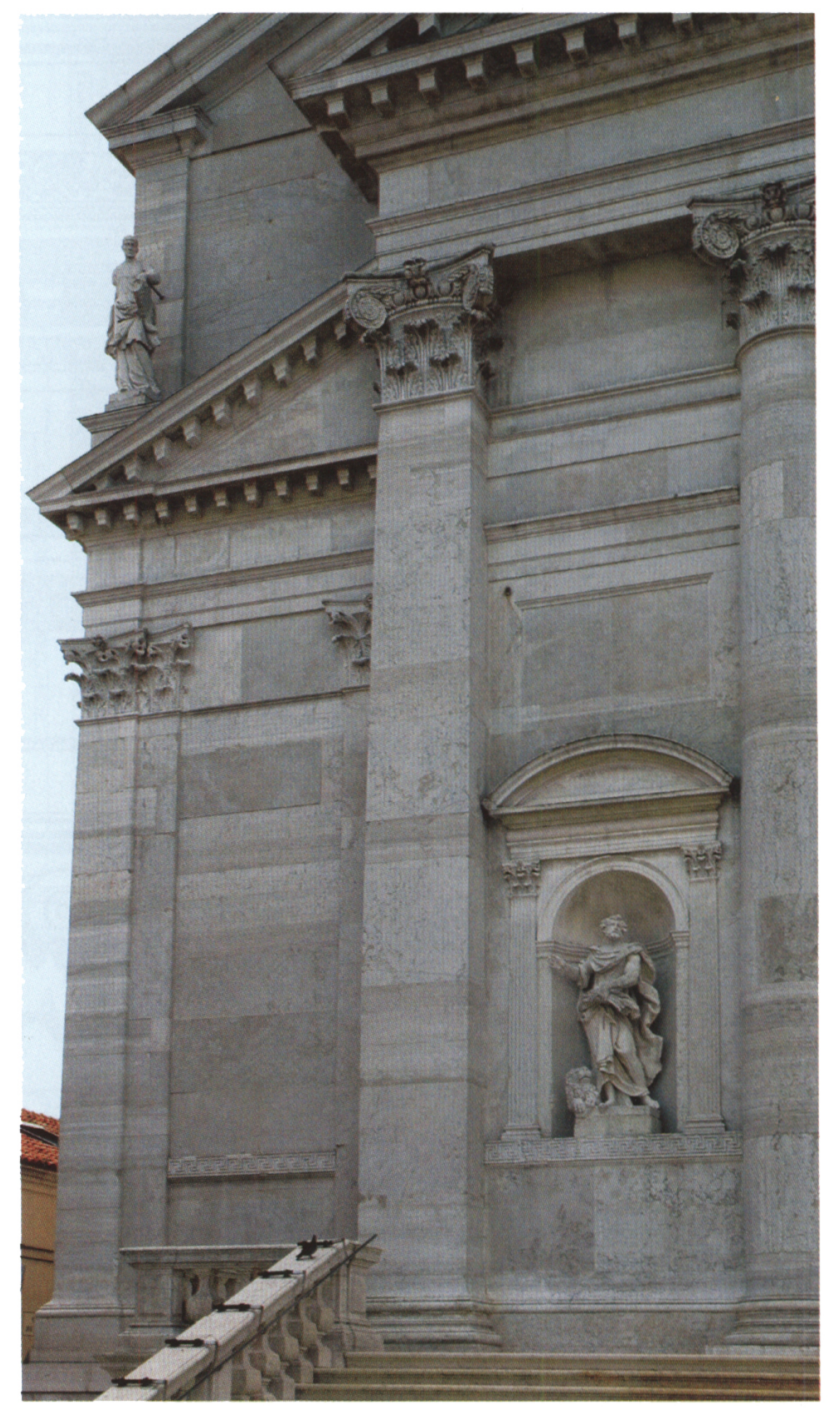

storey of the Colosseum. ${ }^{85}$ Palladio only very rarely used the type of base shown in the treatise's main plates and, whilst sometimes resorting instead to the Attic variety (see e.g. Fig. 11), he employed several others too. His usage of these other types is often connected with his common practice, during his later career, of coupling orders (Corinthian with Corinthian or Composite) of different heights, and combining their closely juxtaposed bases to form unified compositions. As regards the smaller orders, he employed a very simple base consisting of single torus with an extra astragal on the façade of Palazzo Valmarana (Fig. 18) and the façade (Fig. 16) and interior of the Redentore; ${ }^{86}$ and he used the Attic variety with an extra astragal - the type featured in the Quattro libri illustrations - for the façade of S. Francesco della Vigna and the interior 


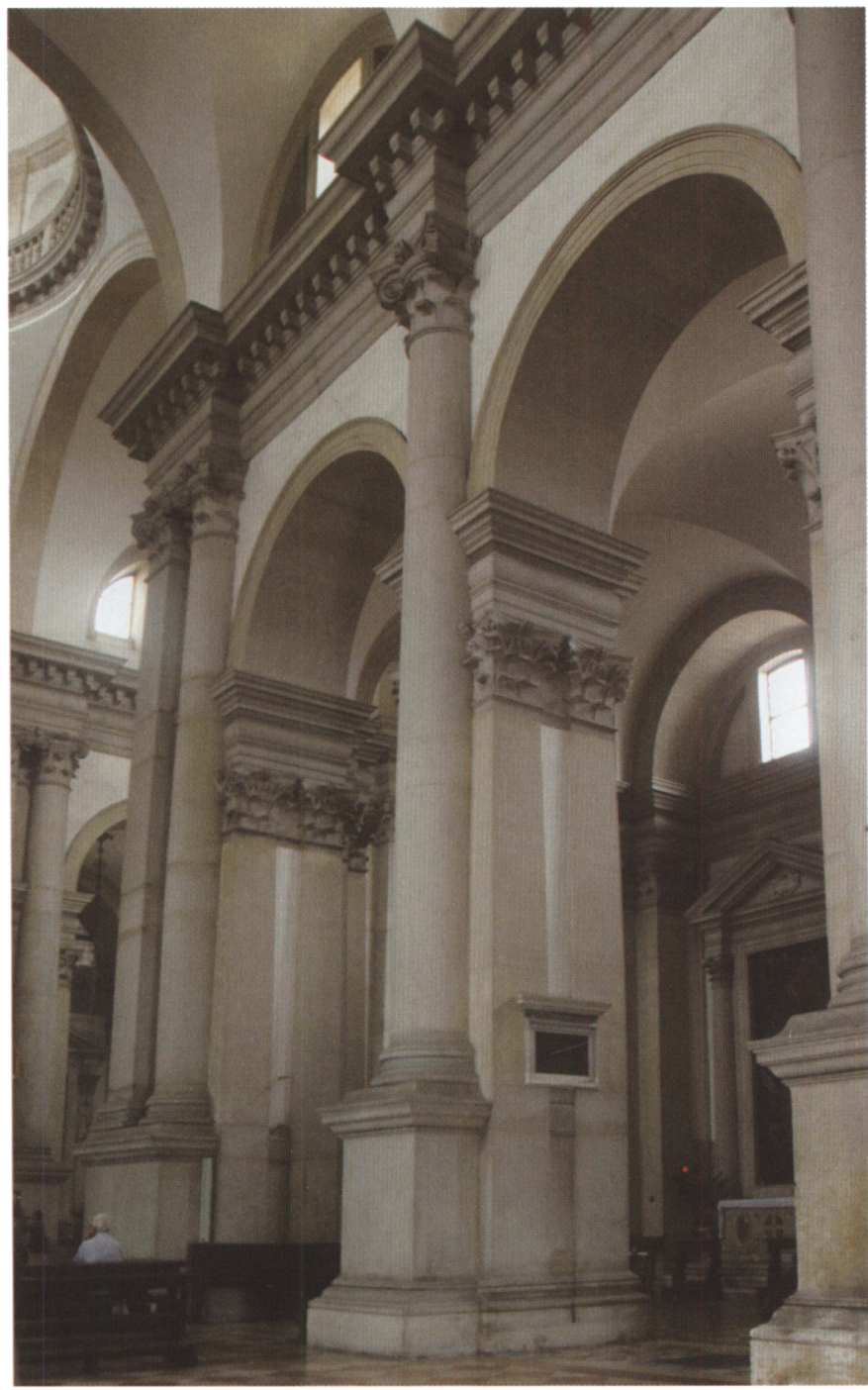

Fig. 17. Palladio's Corinthian and Composite orders: interior of S. Giorgio Maggiore, Venice

of S. Giorgio Maggiore (Fig. 17). As regards the larger orders, he employed the variety shown in the Quattro libri plate of details with three further astragals for the façade of S. Giorgio (if this does indeed accord with his original design) - just as he also did for the pilaster order of his Cappella Valmarana in Vicenza's S. Corona (c. 1576) (see Fig. 26) - and he used even more elaborate varieties as well. The type he employed for the main façade order of S. Francesco della Vigna is similar to the 'Pantheon' base but with an additional astragal at the top, like the variety used for the Temple of Castor and illustrated in Book Four; ${ }^{87}$ whilst the type he chose for the main interior order of the Redentore is like the 'Pantheon' base but now with two extra astragals. Shafts are almost never fluted ${ }^{88}$ and entablatures diverge from the examples illustrated in Quattro libri 
Fig. 18. Palladio's Corinthian and Composite orders: façade of Palazzo

Valmarana, Vicenza

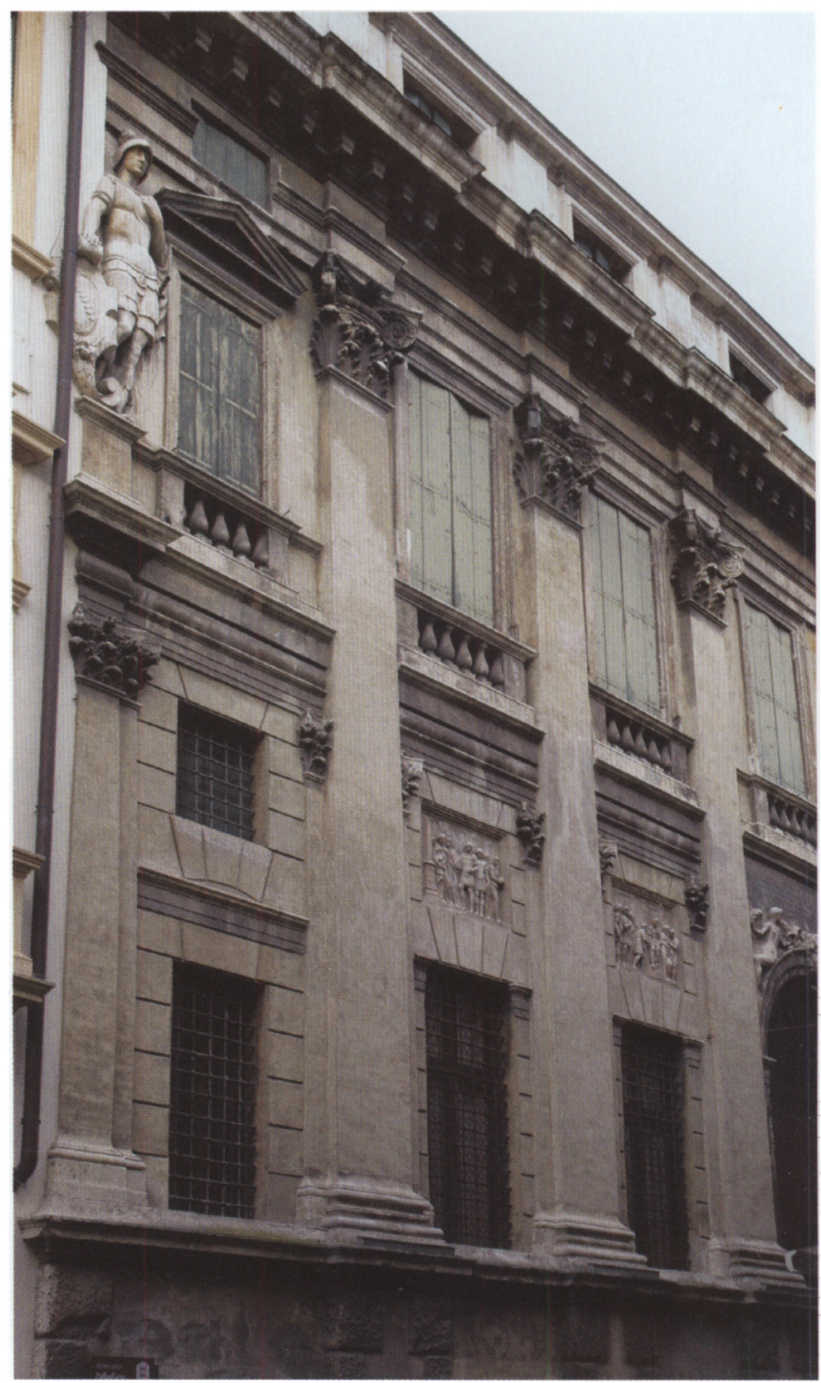

very widely and with great variation in the choice and sequence of components, and unlike in the illustrations they are rarely enriched with carving. Architraves normally, although not always, have three fascias, whilst friezes are often of the pulvinated variety, a type often associated with the Ionic order but also a feature of the Corinthian Temple of Hadrian (Fig. 15) and the Composite Lateran Baptistery (Fig. 19) and church of S. Costanza in Rome, which are all illustrated in Book Four ${ }^{89}$ Cornices take a variety of forms, and, like those used for the Pantheon, they often include an overhanging slab beneath the corona, while the corona itself, in orders used for upper storeys or those that are especially tall, is frequently supported upon simple modillions of the type, again, with undulating lower surfaces. For both the giant order on the façade of $\mathrm{S}$. Francesco della Vigna and the smaller order on that of the Redentore (Fig. 16), however, the 


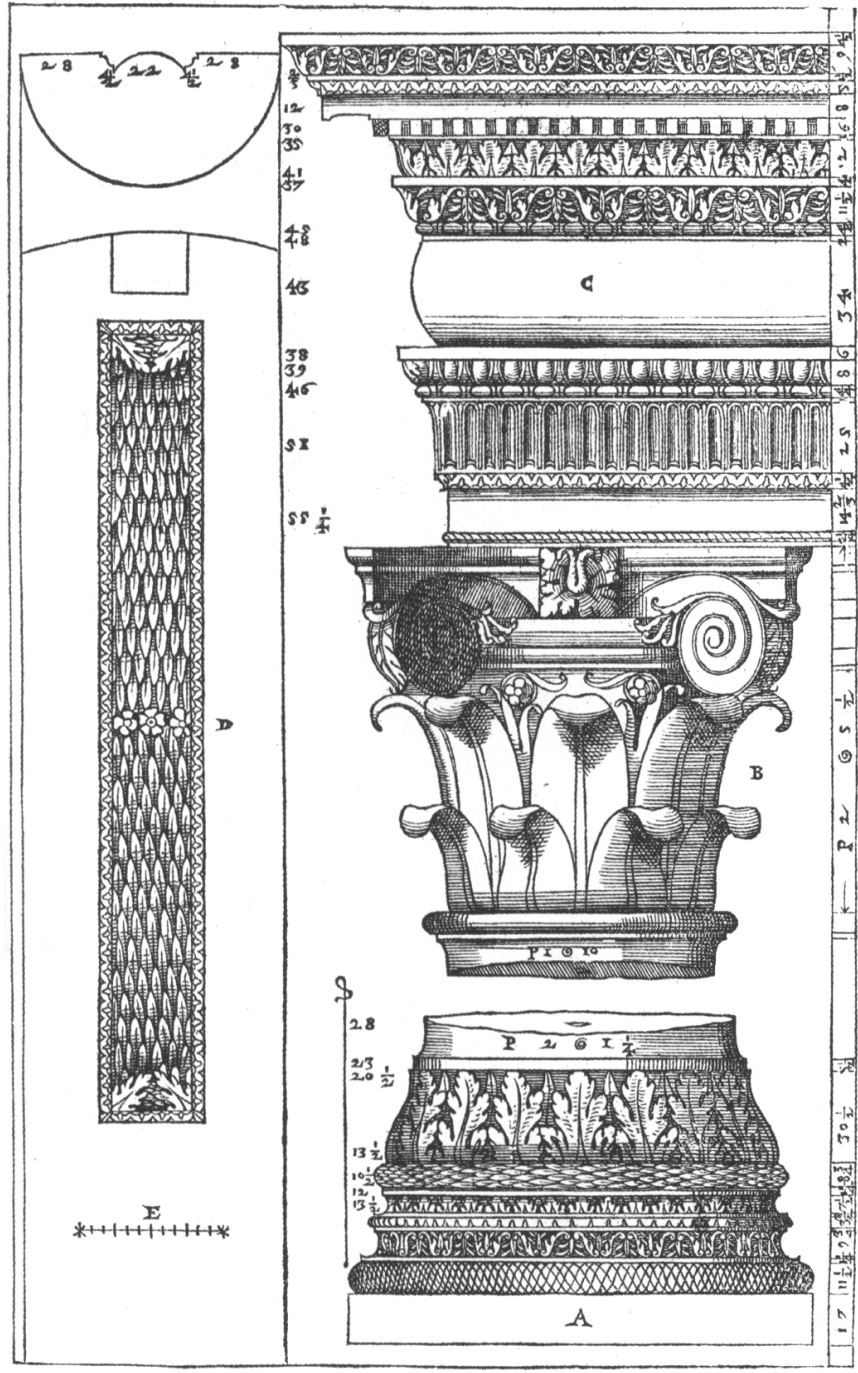

Fig. 19. Composite order of the Lateran Baptistery (I quattro libri, Book 4, p.63)

modillions are of a more unusual double-tiered variety seen in certain temples, such as that, again, of Hadrian (Fig. 15). ${ }^{90}$

\section{PALLADIO'S COMPOSITE ORDER}

Palladio, in the Quattro libri, differentiated the Composite order from the Corinthian in both its formal composition and its more attenuated proportions. The proportions, at 1:10, are the most slender of all the orders presented in the treatise, and they are also in line with the recommendations of previous theorists (Table 1), despite silence from Vitruvius, and only limited support from ancient practice; Palladio himself, for instance, illustrates no such examples in his Book Four (Table 3). ${ }^{91}$ There, the three examples of 
Fig. 20. Palladio's Ionic and Composite orders: exterior (northeast corner) of Palazzo Thiene, Vicenza

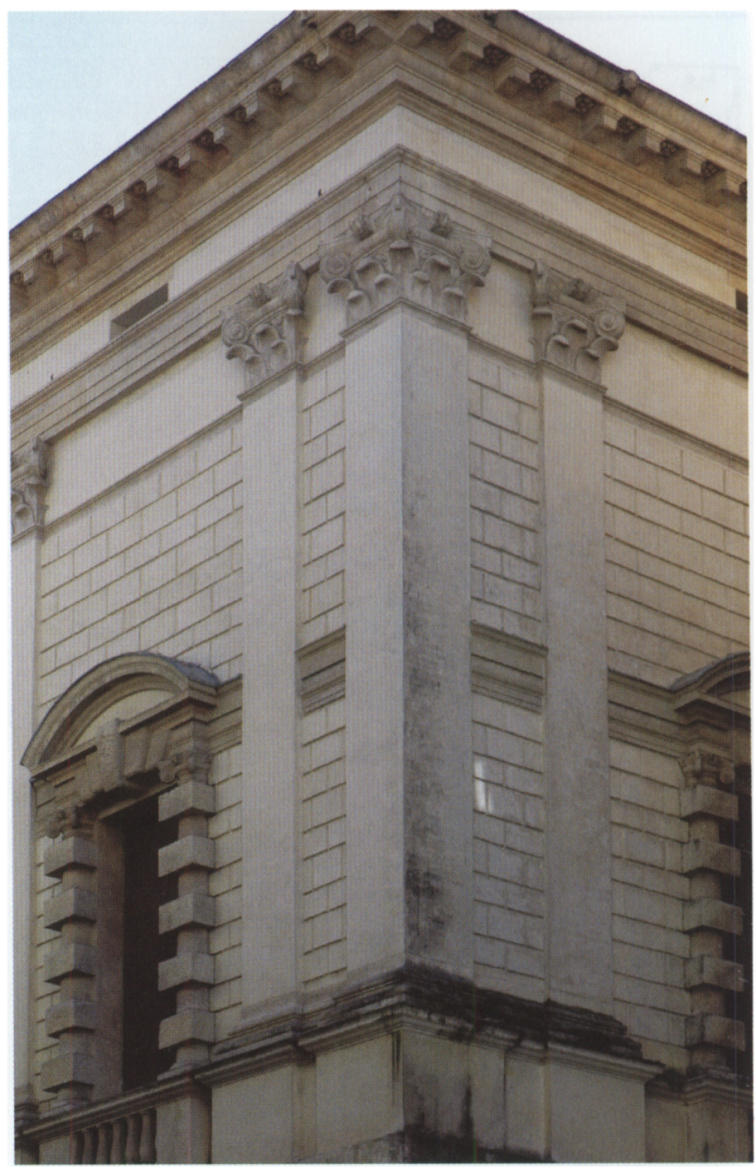

the Composite order all have proportions in the vicinity of 1:91/2 or below. In its formal composition, the order illustrated in the Quattro libri (see Figs 1 and 2) differs significantly from the versions presented by previous theorists. ${ }^{92}$ Palladio followed the lead of his predecessors in basing the capital, with its canted volutes, on those from the Arch of Titus, ${ }^{93}$ rather than any other prototypes (including the examples illustrated in Book Four) ${ }^{94}$ As for bases, for his two main plates he chose the same Attic type with an extra astragal that he also used for his Corinthian order, ${ }^{95}$ but, for one of the plates of details, he opted for the 'Pantheon' variety with an additional astragal. As regards the distinctive entablature, which has an architrave with two fascias and a pulvinated frieze, this accords broadly with the entablature of the Composite order of the Lateran Baptistery (Fig. 19); ${ }^{96}$ but it is even more like the entablature of the Corinthian Temple of Hadrian (see Fig. 15), which has not only a similar architrave and frieze but also a similar cornice, with exactly the same kind of unusual double-tier modillions beneath the corona. ${ }^{97}$

The proportions of the Composite orders in Palladio's works match with the Quattro libri specification of 1:10 with notable consistency (Table 2). This applies both to early usages, such as for Palazzo Thiene (Fig. 20) and Villa Gazzotti at Bertesina (c.1542), 


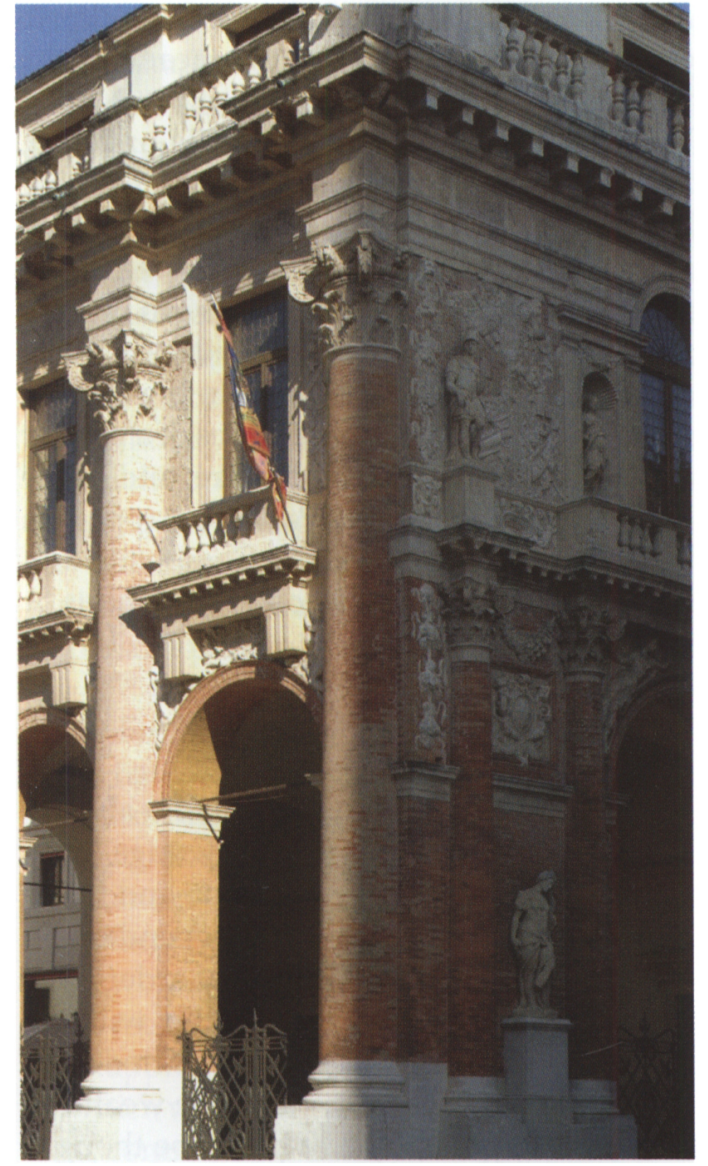

Fig. 21. Palladio's Composite order: façade and side of the Loggia del Capitaniato, Vicenza

which both have pilasters of 1:10 proportions, and to the increasingly more common later ones, such as for Palazzo Porto Breganze, although in several of these schemes, such as Palazzo Valmarana (Fig. 18) and the Redentore (Fig. 16), the order is made even more slender.

The formal composition of the Composite order seen in Palladio's practice, however, is notably varied, and usually very different from the specimens illustrated in the Quattro libri. His capitals are of the same basic type seen in the Quattro libri plates; but, although they are sometimes fully decorated, they often, as in the case of the early Palazzo Thiene (Fig. 20) and Villa Gazzotti, have foliage that is left uncarved, like that of the capitals from the Lateran Baptistery (Fig. 19) that Palladio illustrated in Book Four. ${ }^{98}$ The bases are of various different types, ranging from the simple Attic variety used for Palazzo Thiene and Villa Gazzotti, and the variant with three extra astragals used for the side elevation of the Loggia del Capitaniato (Fig. 21), to designs of even greater extravagance. These include an Attic variant with two pairs of double astragals and a further astragal at the top which was used for the Loggia del Capitaniato façade (Fig. 21), ${ }^{99}$ and the 'Pantheon' type with an additional astragal employed for the giant orders inside 
S. Giorgio (Fig. 17) and the façades of Palazzo Valmarana (Fig. 18) and Palazzo Porto Breganze. A further variant with three extra astragals, featured on the façade of the Redentore (Fig. 16), perhaps takes its cue from the so-called 'Temple of Diana' at Nîmes, which is again included in Book Four. ${ }^{100}$ The shafts are, once more, typically unfluted, but the entablatures are especially varied. Architraves can have either two or three fascias, and the fascias are occasionally slanted, as seen inside S. Giorgio (Fig. 17); ${ }^{101}$ friezes can be plain or, as used for S. Giorgio, pulvinated, following the precedents provided by S. Costanza and the Lateran Baptistery (Fig. 19); ${ }^{102}$ and cornices can include a range of elements, such as the overhanging slab also used for the Corinthian and Ionic orders, and they can either have double-tier modillions of the type seen in the Quattro libri plates or, as in the case of the Corinthian order, they can have modillions of a plainer and simpler variety (e.g. Fig. 17). In fact, such variations to the entablature, and to the design of the Composite order as a whole, are indicative not just of Palladio's approach towards the orders in general but also of a tendency to think of the Composite and Corinthian orders in particular as having elements that were often closely analogous or even interchangeable.

\section{PALLADIO AND PREVIOUS PRACTICE}

From what has now been established, it may have become clear that Palladio already viewed the architectural orders in a notably systemic manner at a very early stage in his career. This approach involved according some respect to ancient precedent, and to the writings of Vitruvius, but, as we have seen, it was by no means slavishly dependent on antique authority. It permitted much variation but allowed each individual order to be distinguishable while having a strong comparability or even interchangeability with the others; and it also relied on a formal vocabulary which was fixed and limited, and actually much more restricted - despite all Palladio's variations - than the wealth of riches that Antiquity had on offer. Palladio's vocabulary can, up to a point, be thought of as a reflection simply of his personal preference. Yet it can also be seen as a considered response - as can his notion of a system more generally - to ideas about the architectural orders developed by architects from the recent past. In fact, his understanding of the orders, which as first formulated in the 1540s appears to have been profoundly indebted to the ideas of certain previous practitioners, came thereafter to form the basis for an approach that he applied, with a remarkable consistency, to all his major schemes.

The young Palladio was very well versed in recent architectural developments not only in the Veneto region where he lived and worked but also in Rome. He spent a considerable amount of time in Rome during stays there in 1541, 1545-46, 1546-47, 1549 and $1554,{ }^{103}$ when he would have acquired detailed and first-hand knowledge not only of ancient architecture but also of the works there of his illustrious predecessors and elder contemporaries. These, of course, included Bramante and Raphael (1483-1520), the architects responsible for initiating the 'High Renaissance' style, as well as for laying the foundations for a modern usage of the ancient orders, and employing a great number of different varieties in their works. ${ }^{104}$ In particular, they did much to establish future norms for both the Doric order, used by Bramante's for his Tempietto (c. 1510; a building 
featured in the Quattro libri) ${ }^{105}$ and his Palazzo Caprini (c.1510; destroyed), and the Corinthian order, used by Bramante (although modified by Raphael) for the interior of St Peter's (designed from 1505) and by Raphael for his Cappella Chigi in S. Maria del Popolo (1513), which in both cases was allocated the 'Pantheon' type of base. Raphael's approach also anticipates Palladio's in the way that he sometimes devised an architectural order on the basis of assembling together a range of components of diverse origin, as is notably the case with the Ionic order of his Villa Madama (1516 and later). ${ }^{106}$ Both these architects, however, were long dead and their practices would probably have had but little direct bearing on Palladio's future approach.

An especially eminent architect who was still living when Palladio first went to Rome and who, by contrast, appears to have made a very deep impression on him, and especially so with regard to his conception and usage of the orders, was Antonio da Sangallo the Younger (1484-1546). Sangallo was not only the dominant architect in Rome for well over two decades after the death of Raphael in 1520; he was also the leading authority of his day on ancient architecture. Palladio could well have encountered him in person, particularly during the almost uninterrupted period he spent in Rome from $1545,{ }^{107}$ and he may have been as awed by his knowledge as Serlio had been, who describes himself as having 'sat' at Sangallo's 'feet'. ${ }^{108}$ Palladio, moreover, would inevitably have come into contact with Sangallo's extensive entourage, who were employed to assist Sangallo in the designing of St Peter's and the realisation of numerous other projects, and who also participated in the painstaking studies of many of Rome's ancient monuments, which are recorded in so many of their surviving drawings.

In fact, Palladio's own investigations into ancient architecture carried out during this time would appear to have been informed to a much greater extent than has usually been recognised by the antiquarian researches carried out by Sangallo and his circle. ${ }^{109}$ This applies to Palladio's drawings both of entire buildings and of their details, many of which were later recast as the illustrations in Book Four of his Quattro libri. This, therefore, contradicts Palladio's implication in the Quattro libri that he alone was responsible for the illustrated reconstructions, and that, as far as the details were concerned, he had measured them all himself ' with the greatest care' ${ }^{110}$ Palladio's early drawings of details include a whole series of sheets showing capitals and entablatures, which provided him with authoritative precedents for his own configurations of the orders, drawings that can frequently be shown to be closely related, in subject and representational technique, to those of details produced in the Sangallo circle. This very clearly applies, for example, to Palladio's rendition of the entablature and other details from the long-demolished Basilica Aemilia (see Fig. 5), which bears a clear family relationship to earlier drawings of it produced by both Sangallo and his brother Giovanni Battista. ${ }^{111}$ It also applies to an early drawing of the entablature of the Temple of Hadrian, which again features in closely comparable studies from the Sangallo circle, and which was later recast as a plate for the Quattro libri (see Fig. 15). ${ }^{112}$

It is also clear that Palladio was particularly attentive to Sangallo's use of the orders in his numerous schemes in Rome, ${ }^{113}$ and that he perceived Sangallo as the preeminent modern-day authority in this regard. In fact, there are many notable features of Sangallo's orders which, subsequently, are equally distinctive - or even leitmotifs - of Palladio's. Sangallo, for instance, made frequent use of the type of Ionic capital with 


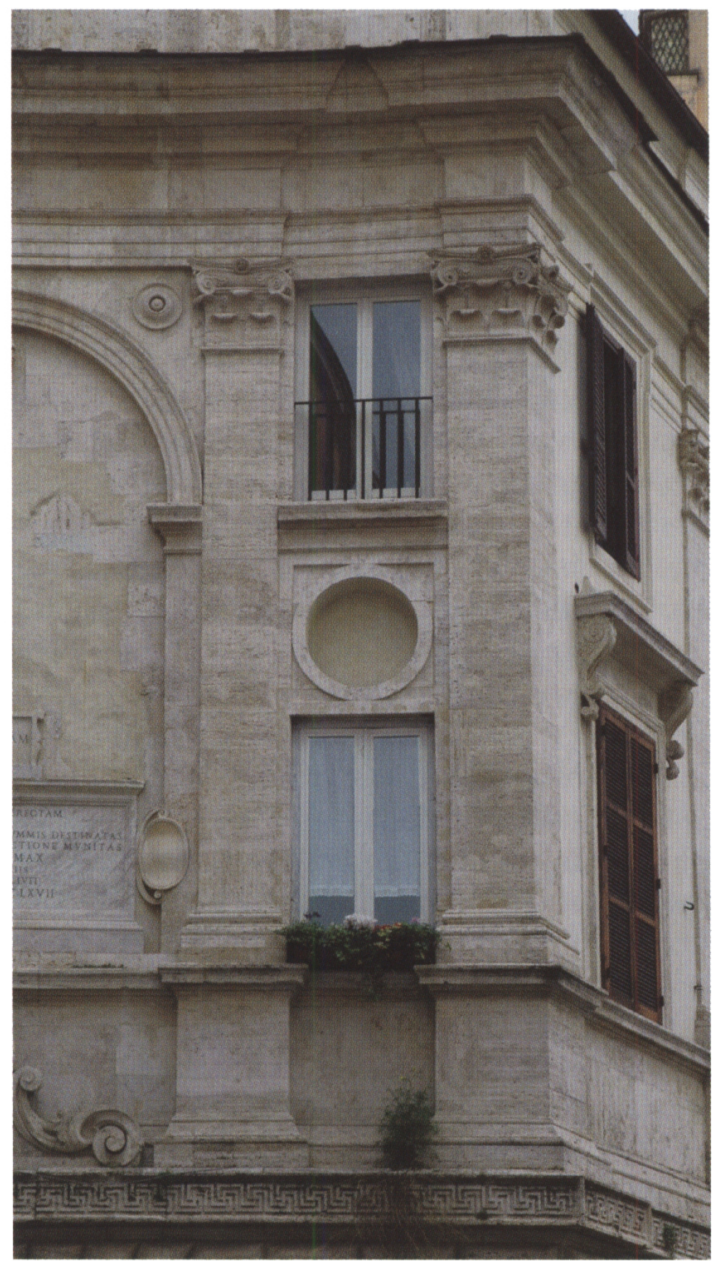

Fig. 22. Rome, Zecca Romana (Antonio da Sangallo)

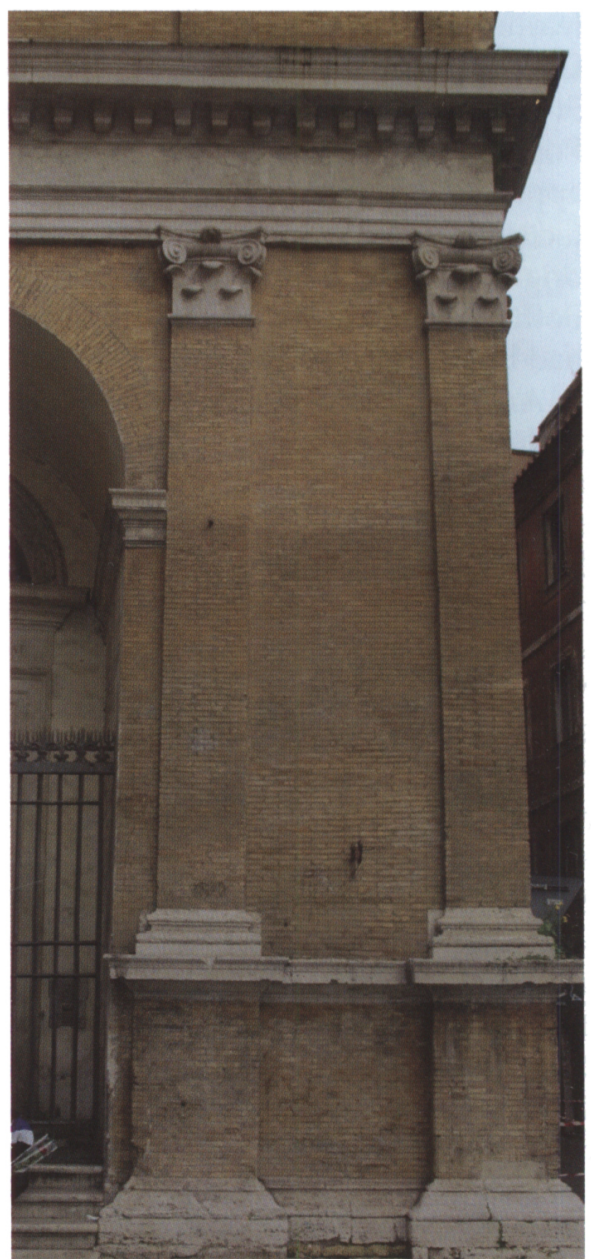

Fig. 23. Rome, S. Maria Porta Paradisi (Antonio da Sangallo)

canted volutes that Palladio very occasionally chose (see Fig. 20); ${ }^{114}$ but for the courtyard of his Palazzo Farnese (1513/14; revised $c .1540$ ) he employed the scroll type (see Fig. 24), similar therefore to the one generally preferred by Palladio. Sangallo, moreover, established the usage of Composite capitals of the Arch of Titus type, ${ }^{115}$ as well as resorting to the variant with uncarved foliage for his Zecca Romana (c. 1525) (Fig. 22), and for his churches of S. Maria di Loreto (1522), S. Maria in Porta Paradisi (c.1525) (Fig. 23) and S. Spirito in Sassia (1538), ${ }^{116}$ the type that Palladio used for the exterior of Palazzo Thiene (see Fig. 20) and elsewhere. Sangallo also used several different types of base, including the Attic base with an additional astragal for his Porta S. Spirito (c. 1542), and the variant with two extra astragals for his Zecca Romana, and he thereby established a practice similar to that taken up subsequently by Palladio. In fact, Sangallo actually pioneered the unusual Ionic base with twin scotias and with paired astragals 


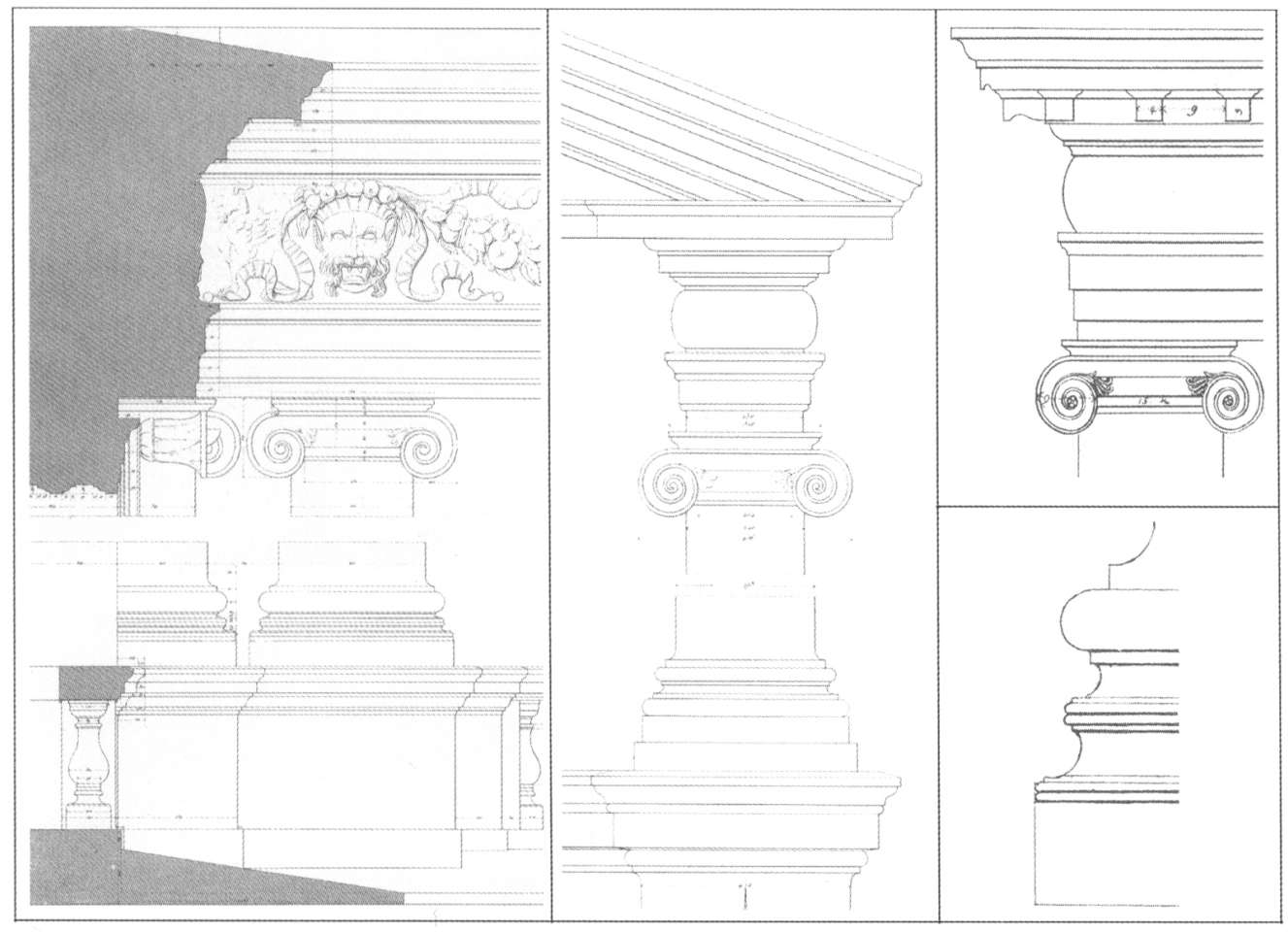

Fig. 24. Sangallo's and Palladio's Ionic orders (after Letarouilly and Bertotti Scamozzi; not to a common scale); left: courtyard of Sangallo's Palazzo Farnese; centre: window tabernacle of Sangallo's Palazzo

Farnese; right top: portico of Palladio's Villa Rotunda; right bottom: base from Palladio's Palazzo

Porta Festa

standing directly upon the plinth, using the type in the courtyard of Palazzo Farnese (Fig. 24), having previously seen and drawn antique examples of similar design, ${ }^{117}$ and Palladio followed his example by employing exactly the same type of base for the façade of his Palazzo Porto Festa (Fig. 24). For the vestibule of Palazzo Farnese, Sangallo deployed a Doric entablature lacking a frieze, ${ }^{118}$ and supported on especially bulky columns, just as Palladio did several times subsequently; and, like Palladio, he also made use of the pulvinated frieze (Fig. 24). Elsewhere, Sangallo opted for a cornice without dentils for both the Ionic middle storey of the Palazzo Farnese courtyard (Fig. 24) and the Ionic upper storey of the courtyard of his earlier Palazzo Baldassini (c.1516), and in this way he had anticipated Palladio's choice of cornice for his Palazzo Porto Festa and all his subsequent Ionic cornices. Moreover, for the Ionic storey of the Palazzo Farnese courtyard, as also for the Zecca Romana (Fig. 22), Sangallo included an unadorned and overhanging slab beneath the corona, just as Palladio did on many occasions, whilst for the façade of S. Maria in Porta Paradisi (Fig. 23) and the upper storey of the Palazzo Baldassini courtyard he included double-tier modillions, ${ }^{119}$ a practice which Palladio would then follow in several of his own schemes (see Figs 16 and 17).

Palladio, in addition, would appear to have been unusually receptive to certain theoretical approaches towards the usage of the orders underpinning Sangallo's practice. 
Rather than regarding the orders as fundamentally different from one another, Sangallo tended to blur distinctions between them. He took the view, for example, that even the three main capital types - Doric, Ionic and Corinthian - could be regarded as having basic characteristics in common, providing diagrams of them on a surviving drawing accompanied by the annotation that they 'are born one from the other' (nascono l'uno dall'altro). ${ }^{120}$ He then followed Raphael's lead when choosing, for example, a type of base, or a component of an entablature such as the overhanging slab or double-tier modillion, for a particular order that was derived from an antique example of a different one, ${ }^{121}$ and, in doing so, employing many of the same base types and entablature components for different orders, much as Palladio did subsequently. Sangallo also adopted a practice, in his usage of bases and entablatures, of selecting a particular type in the context of the design as a whole. Thus he would sometimes choose a base so as to form a harmonious composition with a base or moulding next to it, as can be seen for example in S. Maria in Monserrato (1518), where the bases have additional astragals that correspond with the lowermost mouldings of the adjacent arch jambs (Fig. 25), just as Palladio would later do in, say, his Cappella Valmarana (Fig. 26); and, in certain unexecuted projects, Sangallo sometimes coupled together orders of different sizes, occasionally bringing, like Palladio subsequently, their bases together to form unified compositions. ${ }^{122}$ In a similar spirit, Sangallo occasionally designed his entablatures in accordance with their position in an overall composition, for instance by giving those of tall orders or top stories, such as the upper storey of the Palazzo Baldassini courtyard, the emphatic termination of a row of modillions, in much the same way that Palladio would do subsequently. In addition to all this, Sangallo may have also guided Palladio towards conceiving the orders as a standardised vocabulary of constituent elements that were simply made and often of minimal ornamentation, and so were eminently well suited to cost-efficient construction (see e.g. Fig. 10). ${ }^{123}$

As well as profiting from his experience of Rome, Palladio took great account of recent architectural development in the Venetian territories. He must have paid particular attention to the works of Jacopo Sansovino (1486-1570) in Venice, who was singled out for special praise in the Quattro libri, ${ }^{124}$ but had much less of an impact on Palladio than Giovanni Maria Falconetto (c. 1468-1535) based in nearby Padua and, especially, Michele Sanmicheli (1487/8-1559) in nearby Verona, the pioneers in the region in bringing, as Giorgio Vasari was to note, 'measure' and 'proportion' to columns and orders. ${ }^{125}$ All these architects had explored an extensive usage of different orders in their many schemes, but Falconetto may have been a more direct influence on Palladio's early approach, ${ }^{126}$ such as by anticipating Palladio in using very similar cornices, often including plain and overhanging slabs, for all his orders. ${ }^{127}$ Sanmicheli, for his part, would appear to have affected Palladio's early approach in ways that were even more profound.

Sanmicheli was perhaps the greatest influence not only on Palladio's early conception of the orders but also on his early architecture in general. ${ }^{128}$ It was, for instance, Sanmicheli who had pioneered a modern usage of a Tuscan order of the kind closely informed by the recommendations of Vitruvius, when employing it for the circular chapel of his Lazzaretto complex just outside Verona (1540-4I; mostly executed after 1591); ${ }^{129}$ and Sanmicheli who, earlier, also introduced the baseless Doric order to modern practice in his scheme for Verona's Porta Nuova (c. 1530) ${ }^{130}$ It was Sanmicheli too who 


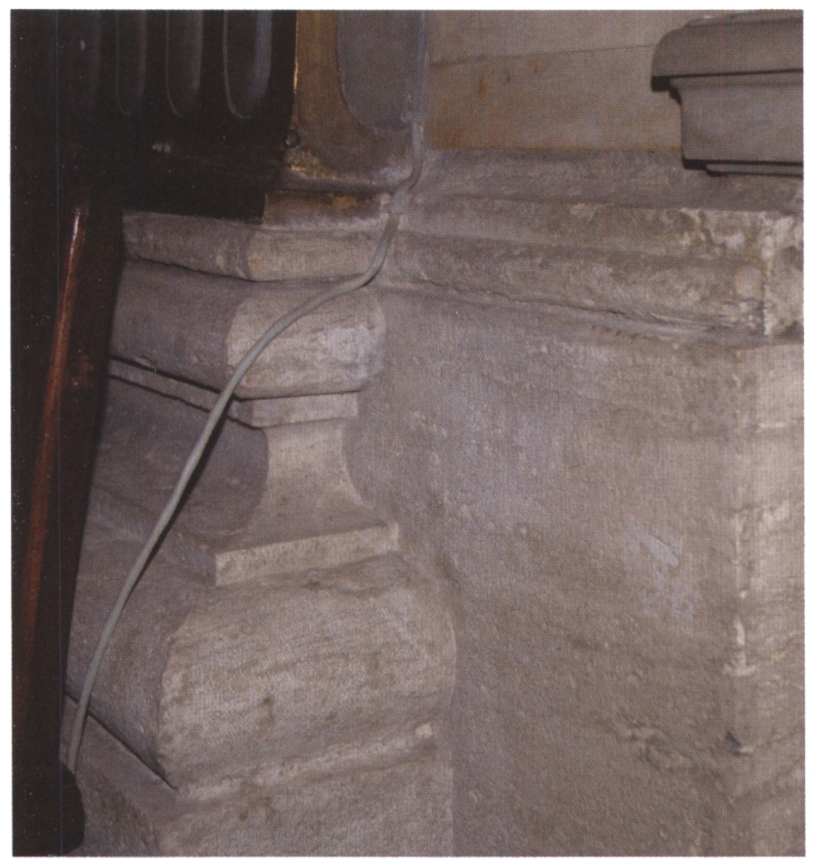

Fig. 25. Rome, S. Maria in Monserrato, bases (Antonio da Sangallo)

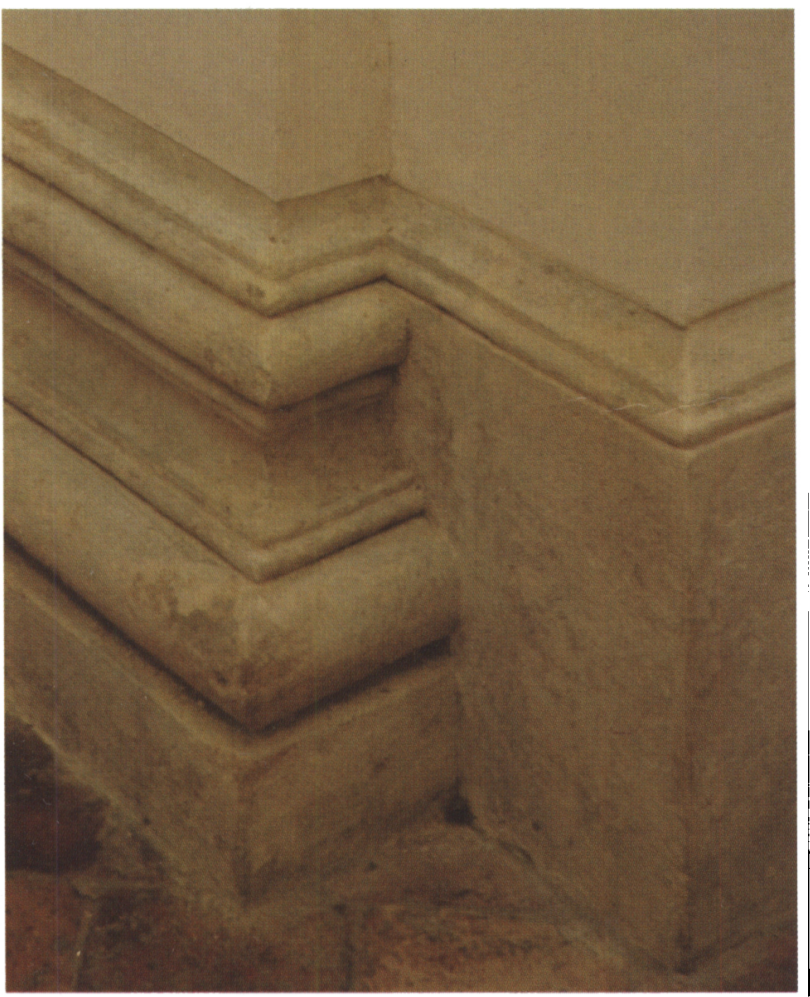

Fig. 26. Vicenza, Cappella Valmarana, bases (Palladio) 
appears to have to have conceived of the three main orders - Doric, Ionic and Corinthian - not simply as a set of different formal assemblages but very much as manifestations of a coherent overall system. This system differed in various particulars from Palladio's understanding of the orders, but it represented a way of looking at them which could well have provided Palladio with an especially important precedent.

Sanmicheli's system, in its coherence and rigour, was unlike any other adopted by practicing architects of the period, and it was followed unerringly in almost all his works in Verona and, later, in Venice, from the moment he resettled in northern Italy in $1526 .{ }^{131}$ According to this system, each of the three orders was given different proportions, ${ }^{132}$ and each was conceived as an assemblage of closely comparable components. The proportions of the Doric order range from a very sturdy 1:61/2 (for the Porta Nuova) up to around 1:81/2 (for Verona's Porta Palio), those of the Ionic order are of around 1:9 but can even reach 1:10, while those of the Corinthian order are of around 1:10 or even as slender as 1:11 (for his Cappella Pellegrini and Palazzo Bevilacqua, both in Verona). The capitals Sanmicheli chose (Fig. 27) were of standard types and were used consistently in all his schemes, and the types were comparable with each other in a similar way to that which Sangallo had described, in that the Ionic capital has a pronounced neck, and hence proportions that are intermediate between those of his Doric and Corinthian capitals. The bases Sanmicheli used were of several different types, and these include, in addition to the ubiquitous Attic variety, the Attic base with an additional astragal, the 'Vitruvian' Ionic base ${ }^{133}$ and the 'Pantheon' base, which were sometimes chosen in conjunction with a particular order (the two latter types with the Ionic and Corinthian orders), although they were also selected to suit the richness and elaboration of the design as a whole. The entablatures Sanmicheli employed (Fig. 27), were likewise standardised, but were of an ingeniously flexible conception in that, for all three orders, their formulation follows a comparable pattern but one that could then be similarly varied in accordance with the richness and elaboration of the overall design. Thus the simplest Doric entablature (as used for Porta Nuova), has an architrave with one fascia and a cornice with just plain mouldings beneath the corona, whereas the most elaborate (used for Porta Palio) has, again, a single-fascia architrave but a cornice now with a band of dentils and also a row of mutules beneath the corona; a typical Ionic entablature has an architrave this time
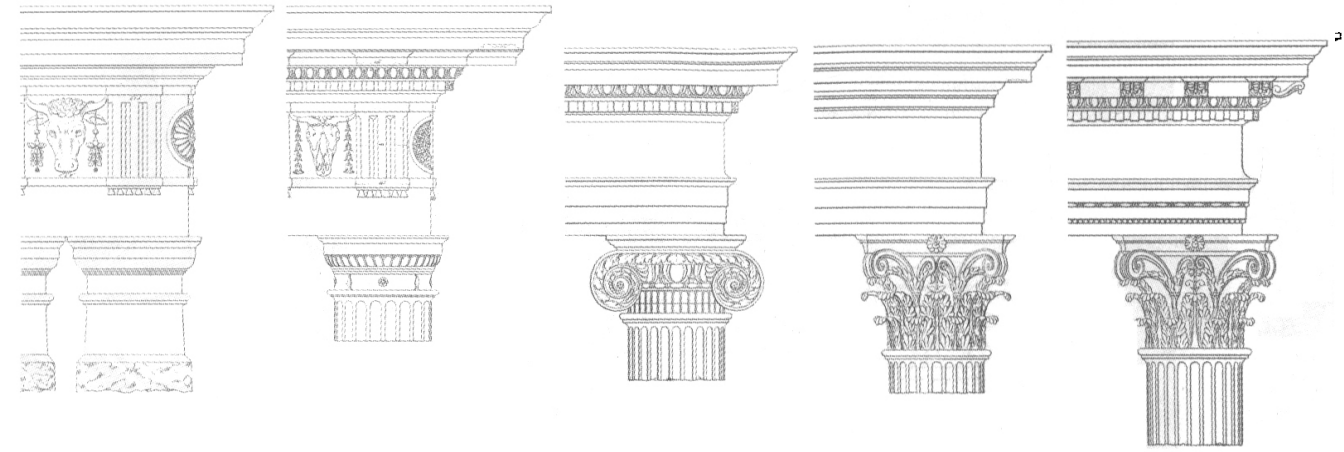

Fig. 27. Sanmicheli's orders (after Ronzani and Luciolli; not to a common scale); from left to right: Porta Nuova; Porta Palio; portal of Palazzo del Podestà; portal of Palazzo del Capitano; Cappella Pellegrini 
with three fascias and a cornice always with a band of dentils; and the simplest Corinthian entablature has an architrave with two fascias and a cornice again with plain mouldings, whereas the most elaborate (used for Cappella Pellegrini and Palazzo Bevilacqua) has an architrave with three fascias and a cornice with a band of dentils and also a row of modillions. ${ }^{134}$ The relevance of all this to Palladio, therefore, is that he, like Sanmicheli, restricted himself to a fixed and finite formal vocabulary for his orders, while conceiving each individual order in an analogous way, and as part of an overall system of notable coherence but also considerable flexibility.

\section{PALLADIO'S ORDERS IN HIS DEVELOPING PRACTICE}

Palladio's system for the orders - or more specifically the Doric, Ionic and Corinthian orders - was already well established by around 1550, if not before, and it then formed a blueprint for his practice long before he even contemplated writing his Quattro libri. This initial system, which can be identified and will now be briefly summarised, was such that each individual order had its own fixed proportions, and each had constituent elements that were different from, although comparable with, those of the other orders. It was formulated at a moment when such systems were most unusual for practicing architects, Sanmicheli aside, and it remained substantially unchanged regardless of the momentous innovations brought by Palladio, from around 1550 , to his conception of the orders in other respects. Palladio's new approach saw a move away from the wellestablished use of small-scale pilasters or half-columns (see Figs 7 and 20); and, instead, it entailed a far greater employment of free-standing columns (see Figs 8 and 10-12), and a frequent recourse to giant orders (see Figs 16-18 and 21), whether applied and often coupled with smaller orders (a further debt to Sangallo), ${ }^{135}$ or free-standing and frequently united with smaller (or 'parastatic') pilasters. ${ }^{136}$ In other words, even despite these fundamental changes, Palladio still remained largely committed to the decisions he had made previously over the proportions and the basic taxonomies of his orders.

The proportions of orders used by Palladio right from the start of his practice were evidently set, like Sanmicheli's, as a series of ranges, even if distinctions were perhaps not quite so rigorously observed (Table 2). Palladio's Doric order, early on, was subject to particularly wide variations, as was described above, but aside from some initial experiments (in particular the highly attenuated pilasters of the early Villas Pisani and Thiene) most examples, whether with bases or not, fall into the range of around 1:71/2$8 \frac{1}{2}$. His Ionic order tended to have proportions in the range of around $1: 8^{1 / 2}-9^{1 / 2}$, and so, like his Doric order, was broadly in line with Vitruvius (see Table 1). The Corinthian order was much more rarely used at this stage but the pilasters of the early Casa Civena, which have proportions in excess of $1: 9^{1 / 2}$, imply a more slender ideal, and possibly an envisaged range from around 1:91/2 upwards, which would have been broadly consistent with ancient precedent (see Table 3); and this appears to be confirmed by the order's even more slender proportions in certain subsequent schemes, starting with Villa Cornaro at Piombino Dese.

The formal makeups of the orders in Palladio's system would, again, appear to have been largely established right from the start of his career, as is suggested by his choices of preferred capital types, which were probably all settled very early on. His aim, in this regard, was presumably to select capital designs that were not just sanctioned by 
Antiquity but, unlike those chosen by many of his contemporaries, were found on the most highly regarded ancient buildings. Thus his Doric capitals, like those generally favoured by Sangallo and other modern architects, were based specifically on the type used for the Theatre of Marcellus (see Fig. 4), a prominent ancient exemplar that came close to the design specified by Vitruvius. Other esteemed models, such as the more ornate capitals of the Basilica Aemilia (see Fig. 5), which were imitated by Sanmicheli and others (see Fig. 27), were at this stage rejected. Palladio's usual Ionic capitals, like those used by Sangallo for the Palazzo Farnese courtyard (see Fig. 24), ${ }^{137}$ are of a similar type to those from, again, the Theatre of Marcellus, although they were more meticulously modelled on the capitals of the Temple of Portumnus (see Fig. 9), which likewise conform closely to the design described by Vitruvius. Other possibilities such as the more elaborate types with necks that were used by Sanmicheli (see Fig. 27) and other architects, were again discounted. Palladio's Corinthian capitals were modelled as closely as possible on the antique prototypes provided by the Pantheon and the Temple of Minerva (see Fig. 14); and his Composite capitals were based, in their composition, on those from the Arch of Titus, rather than any other ancient monument, this being the general type championed again by Sangallo. ${ }^{138}$

In selecting the other components of the orders for his schemes - their bases and the elements of their entablatures - Palladio again took note of the practices of his predecessors. He thus followed the examples of Sangallo and Sanmicheli in using an extensive range of base types modelled on antique exemplars, although he avoided the theoretical 'Vitruvian' Ionic base despite this being a well-established option; and, like his predecessors, he tended to use different types of base in accordance with different orders or with distinctions between orders. He also followed Sangallo's lead when, from around 1560, he began using the Corinthian and Composite orders with much greater frequency and often in combinations, and this is what led him to turn to an even greater range of types. He conceived his entablatures in a way that again utilised many antique-derived features established previously by Sangallo, and in a way that allowed great flexibility of choice and, when desired, a hierarchical distinction between different orders, while also permitting, rather as in Sanmicheli's practice, the entablatures of one order to be highly comparable to those of another. Thus architraves with single or doubled fascias tended to be used for the Doric order whereas those with three fascias were more usually associated with the Ionic, Corinthian and Composite orders. Although friezes with triglyphs and metopes were reserved for the Doric order, the triglyphs and metopes were sometimes omitted, while pulvinated friezes were used not just for the Ionic order since they were also chosen for the Corinthian and Composite orders. Cornices could either be simple, in which case a Doric cornice could be compositionally very similar to simpler cornices employed for the other orders, or else they could be more complex, such as by including unadorned slabs, or, as in the cases of the Ionic, Corinthian and Composite orders, rows of modillions beneath the corona. It would thus have been for reasons partly of comparability that Palladio made the cornices of his Doric entablatures more elaborate than the one specified by Vitruvius, and for reasons partly of comparability (as well as cost) that he avoided mutules, and also chose to omit the usual bands of dentils from the cornices of his Ionic, Corinthian and Composite orders.

It may well be that, initially, Palladio followed Sanmicheli by envisaging a system that encompassed just the Doric, Ionic and Corinthian orders, and that he adapted this system 
only later to include the Tuscan and Composite. It would have been relatively straightforward for him to add the Tuscan order to his original system, in that Vitruvius had specified proportions of 1:7; and Palladio may have simply decided on a proportional range of, say, 1:7-7 $1 \frac{1}{2}$, which, as put into practice in the early 1550 for his Villa Trissino at Meledo, fitted very conveniently with his chosen range of $1: 7^{1 / 2}-8 \frac{1}{2}$ for the Doric order. It was far more problematic, however, to accommodate the Composite. Palladio's solution, seen in at least some of his schemes from after 1560 , and perhaps beginning with S. Maria della Carità, was to limit the proportions of the Corinthian order to around 1:91/2, and thereby reserve for the Composite the more slender proportions of 1:10.

In conceiving of the Composite in this new way, and thus at the top of a hierarchy of the orders, Palladio was now departing from his own earlier practice, which saw the Composite orders of his Palazzo Thiene (see Fig. 20) and Villa Gazzotti being given very plain and simple forms, as well as from the practices of his mentors Sangallo and Sanmicheli. Sangallo may well have viewed Composite, at least at some stage, as a variant of the Corinthian, ${ }^{139}$ whilst Sanmicheli evidently saw it as being subservient, for example by using it, for his Cappella Pellegrini, as a minor pilaster order coupled with a taller order of Corinthian half-columns. ${ }^{140}$ Nor was Palladio's characterisation of the Composite as the supreme order, as finally codified in the Quattro libri, decisively shared by other theoreticians of his time (see Table 1). Vignola, for example, had given both the Composite and the Corinthian the same proportions of 1:10, and did not otherwise differentiate between the two in any clear manner; ${ }^{141}$ and, later, Vincenzo Scamozzi (1548-1616) was to reverse Palladio's hierarchy (in one of his two main illustrations of the orders) by placing the Composite, which was now given the proportions of $1: 9^{3 / 4}$, below and not above the Corinthian, which was instead allocated the proportions of 1:10. ${ }^{142}$ That said, Palladio's eventual ennoblement of the Composite order - despite the contradictions seen in his practice - was certainly anticipated by Serlio, as well as by the theoretical prescriptions of others regarding a five-order hierarchy that had been expressed previously. ${ }^{143}$ Perhaps more immediately relevant, however, is that it also followed on from sporadic initiatives in previous northern Italian practice, which saw Falconetto in Padua, for example, give his Porta Savonarola (1530) a Composite order and thereby distinguish it from his earlier Porta S. Giovanni (1528) which has a less elaborate Corinthian order; $;^{144}$ and it was probably motivated in particular by a well established vogue for the Composite order in Venice, as conspicuously employed, for example, for the exterior of Cappella Zen (c. 1506-12) attached to St Mark's (the work of Tullio Lombardo), ${ }^{145}$ and for Sansovino's Loggetta (1536) in nearby Piazza S. Marco, where the order was executed in especially rich materials to match the highly lavish handling of the design as a whole..$^{146}$

\section{PALLADIO'S ORDERS AND THEIR SYSTEMS IN THE QUATTRO LIBRI}

In deciding to write his treatise and include a book largely devoted to the architectural orders, Palladio now had different objectives and had to adapt his previously established system accordingly. It is hardly surprising, therefore, that the system explicated in Book One of the Quattro libri not only differs from the previous formulations of Serlio and Vignola but also departs, both in the limitation of its coverage and in certain other respects, from Palladio's own earlier practice, because he was now faced with conflicting 
pressures. On the one hand, he presumably wished somehow to encapsulate the theoretical outlook underpinning his concurrent practice but, on the other, he needed to present his schema for the orders to best advantage and in such a way as to impart it with the greatest authority. To this end, he brazenly decided to appropriate the illustrative formula devised by Vignola, who had similarly represented the orders through sequences of plates showing colonnades (Fig. 28) and arcades (two sets) along with additional plates of details. ${ }^{147}$ In some respects, however, Palladio improved upon Vignola's engraved illustrations, by deciding on woodcut plates that promoted greater simplicity and clarity, and having his specimen designs accompanied by often highly technical commentaries (perceptively discussed elsewhere), ${ }^{148}$ so as to endow them with a strongly theoretical dimension, which could be regarded as also underpinning the presentation elsewhere in the treatise of his own schemes.

For the Quattro libri, Palladio had to allocate to the orders his own set of so-to-speak 'ideal' proportions (see Table 1 ), in a way that he knew would inevitably differ from those ordained by previous theorists, but in one that needed to appear to be theoretically sound, even if this meant skating over certain inevitable difficulties. He thus specified proportions for the Tuscan order (1:7) that tallied with Vitruvius, and he indicated a theoretically reasonable norm, broadly founded on his own practice and again consistent with Vitruvius, for the Doric order $\left(1: 7^{1 / 2}\right.$ or $\left.1: 8\right)$. Although he then fudged the matter but in doing so endorsed his own practice - by explaining that a Doric order without a base was differently proportioned from one having a base (the latter $1: 82 / 3$ ); and then, in much the same vein, he proposed a theoretically justifiable norm for the Ionic order (1:9), likewise founded on his own practice and consistent with Vitruvius, before simply asserting the recently decided distinction, seen only intermittently in his practice, between the proportions of Corinthian order $\left(1: 9^{1 / 2}\right)$, and those of the Composite order (1:10). The result may not have been perfect but it still managed to convey a degree of internal logic, by forming a fairly neat sequence running from $1: 7$ to $1: 10$.

In deciding on the formal compositions for the specimen orders in the Book One plates, Palladio was faced with various conflicting aims. One, presumably, was for the illustrations to be as eye catching as possible, and this was achieved in good part by way of their ornamentation, in that columns are normally given flutes (unlike Vignola's), while capitals and entablatures, especially in the plates of details, are often also embellished. This, therefore, resulted in a departure from Palladio's practice, where simplicity in the treatment of the orders and variations of ornament are such prominent characteristics. It also helps explain why some of the individual illustrations, especially the detail plate of the Corinthian order noted previously, are so similar in ornamentation - and constitution - to their preceding equivalents in Vignola's treatise. ${ }^{149}$ Another probable aim, however, was to make the illustrations comply, at least to a degree, with Palladio's principle of comparability between the orders. Although this was often impossible to achieve, it still helps explain why Palladio sometimes departed, as we have previously observed, from strict Vitruvian orthodoxy or ancient precedent, ${ }^{150}$ as well as why he devised an alternative formulation for the Tuscan order that was more closely analogous to those of his other orders (see Fig. 2). It also provides a reason why the plinths, in the arcade plates of the Doric, Ionic, Corinthian and Composite orders, are all of the same unusual type with a flared rather than a straight profile. ${ }^{151}$ 

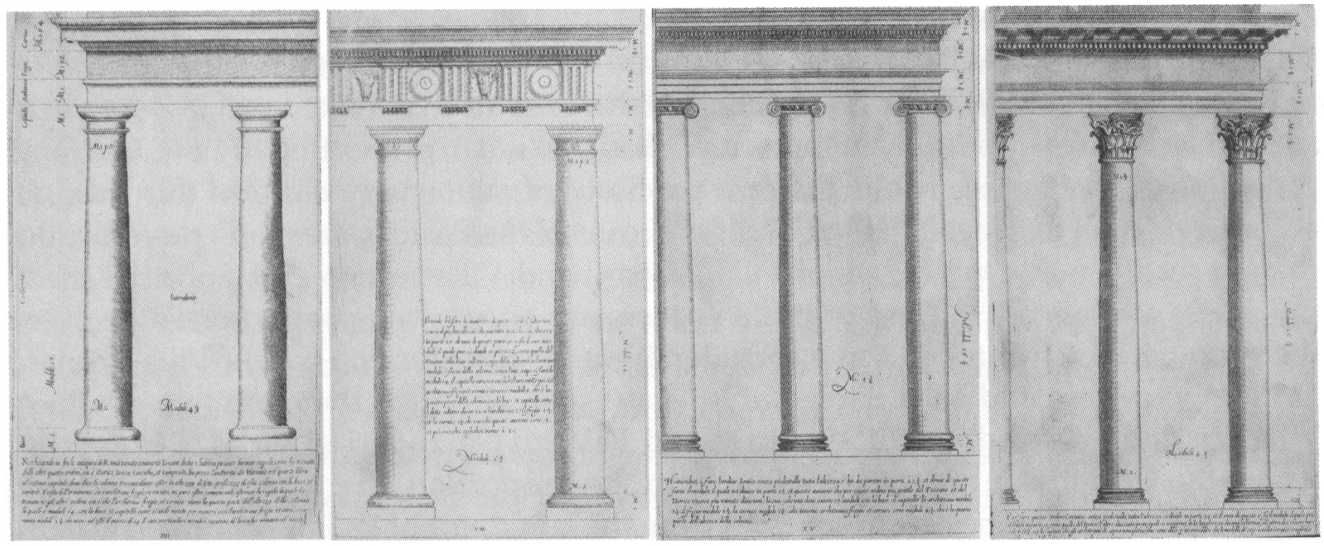

Fig. 28. Vignola's orders shown as colonnades (Regola, pp. 4, 9, 15 and 21)

Yet another aim, of course, was to use the treatise as a means for parading preferred capital types, and illustrating a selection of the bases and the elements of entablatures that Palladio habitually employed in his practice, even though this frequently forced him into making rather arbitrary choices, and often emphasised differences between the orders rather than, as in his executed work, communalities. From this perspective, the main decisions he made - and the main discrepancies with his preceding activity can be readily summarised. As regards the Doric order presented in the Quattro libri, the capital departs from his practice in having a neck enriched with rosettes, while the entablature, although not identical to any executed example, is still comparable to many in its basic disposition. For the Ionic order, the 'Vitruvian' base he illustrated but never used is given as an alternative to the Attic, perhaps in the interests of theoretical completeness, while the entablature is again typical of his practice in general, and features his favoured options of the pulvinated frieze and the row of modillions. In the case of the Corinthian order, the bases illustrated are just two of the several varieties found in his executed work, both being Attic types with additional astragals, while the entablature with its row of modillions is again broadly typical, although the one included in a plate of details also features (as again mentioned previously) a band of dentils, ${ }_{152}$ which are never seen in his practice. Finally, for the Composite order, the bases chosen, namely the Attic and 'Pantheon' types with extra astragals, are likewise just two of various possibilities seen in his practice, while the entablature takes up the occasional options seen in his work in having an architrave with just two fascias, a pulvinated frieze and double-tier modillions, but with the result that it is much more clearly differentiated from the Corinthian entablature than was normal in his preceding work.

To a considerable degree, the Book One orders also tally, in their proportions, with the illustrations of Palladio's own schemes later in the treatise. In other words, the schemes appear to have been drafted to give their orders dimensions that were often more consistent with Palladio's specified ideals than with reality (Table 4). ${ }^{153}$ Thus, the many Doric orders in these illustrated schemes (a good number never realised), usually have proportions in the range of $1: 7^{1 / 2}-8$ (even if some examples have bases), and they 
often have proportions that are very nearly or even precisely of the 'ideal' $1: 7^{1 / 2}$ or 1:8. The Doric pilasters of Villa Thiene at Quinto are still unusually slender in the illustration of this scheme, ${ }^{154}$ but they are given adjusted dimensions that make them less slim than they are in reality, and closely in line with Palladio's 'ideal' proportion of $1: 82 / 3$. The Ionic orders often have proportions that are precisely of 1:9 or very close to this ratio. In accordance with this ideal, the Ionic half-columns of the Basilica are made more slender than in reality, while the orders of Villa Barbaro and Villa Sarego at S. Sofia are made much less attenuated. ${ }^{155}$ The Corinthian orders are often given proportions of $1: 9^{1 / 2}$ or thereabouts, which entailed some considerable adjustment in the case of Villa Cornaro at Piombino Dese and Villa Sarego at Miega (1562), although there are two schemes, Villa Trissino at Meledo and the unexecuted Palazzo Garzadori in Vicenza (c.1555), ${ }^{156}$ where the Corinthian orders are tellingly in the proportion of 1:10. ${ }^{157}$ The Composite orders, which mostly belong to schemes from the latter part of Palladio's career, usually concur with reality by being given proportions very consistently of 1:10.

Palladio even made decisions, in the Quattro libri, about the way he depicted the orders in his schemes, so as to make them appear to conform better to his most recent thinking. Thus, he often provided large-scale and detailed illustrations of those schemes or parts of schemes, such as the Palazzo Chiericati façade and the Basilica arcades, which have orders that are reasonably consistent with those illustrated previously in Book One. ${ }^{158}$ On other occasions, however, he played down certain obvious incongruities, such as when making the projecting blocks in the Ionic friezes of the Palazzo della Torre courtyards barely noticeable in the Quattro libri plate, ${ }^{159}$ or else he simply avoided showing them at all, as was the case with the courtyard of Palazzo Valmarana, with its similarly projecting blocks. On yet other occasions, however, he actually adjusted the illustrations to remove problematic features and thereby make his designs more consistent with his Book One ideals, such as by avoiding showing the uncanonical dentils in the Doric entablature of the courtyard of S. Maria della Carità. ${ }^{160} \mathrm{He}$ even substituted the smaller Ionic capitals of the Basilica, which actually have short necks, with his preferred type that has none, and he expunged the unorthodox Ionic bases from his façade illustration of Palazzo Porto Festa and replaced them with the standard Attic type, perhaps because he now considered them to be insufficiently grounded in distinguished ancient precedent. ${ }^{161}$

The Quattro libri plates of the orders also embody yet other principles and systems (investigated elsewhere in some detail), ${ }^{162}$ and these, again, tally in part with principles previously explored in Palladio's practice, as well as making his illustrations far more sophisticated than those of his theoretician predecessors. In the arcade plates (see Fig. 2), for example, Palladio indicated a system for the sizing of pedestals, which become progressively more slender over the five-order sequence, an idea also set out by Serlio and Vignola in their treatises, ${ }^{163}$ and one occasionally followed by Palladio in some of his executed schemes (see e.g. Figs 8 and 17). In both the main sets of illustrations (see Figs 1 and 2), albeit with the exception of the first of the Tuscan plates, Palladio also suggested a principle for the sizing of entablatures, which become proportionally shorter over the sequence, just as the diameter of the columns or half-columns becomes incrementally narrower, ${ }^{164}$ a principle enunciated by neither Serlio nor Vignola (Fig. 27), but seen in Palladio's realised schemes, and one that perhaps helps explain why his 
Doric order usually has a cornice with additional mouldings, and why his Corinthian and Composite orders sometimes have architraves with just two fascias rather than three, and can also have cornices that are relatively simple (see e.g. Figs 16-18). Palladio, in addition, set out guidelines in the two main sets of plates for the spacing of the orders, an idea that had been previously mooted by Vignola in his colonnade plates (Fig. 28), but not with the sense of purpose that is inherent in Palladio's approach to the matter. ${ }^{165}$ In Palladio's arcade plates, the spacing, together with the width of the framed arches, becomes ever narrower in relation to the order's height, while, in his colonnade plates, the spacing or intercolumniation becomes similarly narrower and, moreover, the different spacings are matched in Palladio's commentary (albeit not precisely) with Vitruvius's rules for the different spacings of columns for temples. ${ }^{166}$ This same principle had similarly been addressed by Palladio in his previous practice, insofar as he tended to space, say, his Doric columns (see e.g. Fig. 7) more widely than his Ionic or Corinthian columns (see e.g. Fig. 11), and often far more widely than in façades or elevations that featured the Corinthian or Composite orders (see e.g. Figs 17-18).

Palladio's conception of the architectural orders, in the final analysis, turns out to be much more than just of passing interest in the context of the development of architectural thought during the sixteenth century. In the Quattro libri, the orders are far from being, as it has been claimed, representative of an 'undogmatic stance' towards the antique, and largely reliant on earlier theoretical positions. ${ }^{167}$ Nor was their adumbration there in any other sense a 'paper' exercise: one that was contingent primarily on previous publications - even if this is how it has come, by some, to be viewed. Instead, and as we have now seen, the Quattro libri orders were the final products of thirty-years-worth of thought and, almost certainly, fiercely held conviction. In fact, the Quattro libri treatment of the order is rather like a palimpsest preserving the indelible imprint of an initial outlook towards the orders that underpinned the architect's own practice, which was conceived long before, and which was then overlain by revised perspectives before being ingeniously redrafted, and invested with further theoretical concerns, so as to be eminently well suited to an architectural publication. Therefore, Palladio's initial formulation of the orders, which has its origins firmly in the earliest phases of his career, was remarkable for its time, and was - as it will now have become very clear - a momentous step in architectural thinking. It will be clear, too, that the Quattro libri versions of the orders represent a distillation of this previous practice, as well as, in effect, the quintessence of his entire outlook towards classical architecture.

\section{ACKNOWLEDGEMENTS}

This study has benefitted immeasurably from the repeated hospitality offered me by the Centro Internazionale di Studi di Architettura Andrea Palladio in Vicenza, now the home too of the Palladio Museum. I would like to express my profound gratitude, in particular, to its director Guido Beltramini for his continual encouragement, and to its president Howard Burns for sharing with me, over very many years, innumerable insights, as well as to my friends and colleagues Paul Davies and Richard Schofield for their countless helpful and perceptive comments and clarifications. 
TABLE 1: Proportions of the orders according to successive theorists

\begin{tabular}{llllll}
\hline & Tuscan & Doric & Ionic & Corinthian & Composite \\
\hline Vitruvius & $1: 7$ & $1: 7 / 1: 7^{1 / 2}$ & $1: 9 / 1: 81 / 2$ & {$\left[1: 9^{2 / 3}\right]$} & - \\
Alberti & - & $1: 7$ & $1: 9$ & $1: 8$ & - \\
Serlio (1537) & $1: 6$ & $1: 7$ & $1: 8$ & $1: 9$ & $1: 10$ \\
Vignola (1562) & $1: 7$ & $1: 8$ & $1: 9$ & $1: 10$ & $1: 10$ \\
Cataneo (1567) & $1: 6 / 1: 7$ & $1: 7$ & $1: 8 / 1: 81 / 2 / 1: 9$ & $1: 9$ & $1: 10$ \\
Palladio (1570) & $1: 7$ & $1: 7^{1 / 2-8 / 1: 83 / 3}$ & $1: 9$ & $1: 9^{1 / 2}$ & $1: 10$ \\
Scamozzi (1615) & $1: 7^{1 / 2}$ & $1: 81^{1 / 2}$ & $1: 83 / 4$ & $1: 9^{3 / 4} / 1: 10$ & $1: 10 / 1: 9^{3 / 4}$ \\
\hline
\end{tabular}

TABLE 2: Executed schemes by Palladio that are recorded by Bertotti Scamozzi Measurements in feet (for further information, see n. 11)

\begin{tabular}{|c|c|c|c|}
\hline & Diameter/width & Height & Ratio \\
\hline \multicolumn{4}{|l|}{ Doric Orders } \\
\hline $\begin{array}{c}\text { Palazzo Thiene, Vicenza (1542): } \\
\text { androne }\end{array}$ & $1.27 \mathrm{ft}\left(1^{\prime} 3^{1 / 4^{\prime \prime}}\right)$ & $10.07 \mathrm{ft}\left(10^{\prime} 05 / 6^{\prime \prime}\right)$ & $1: 7.92$ \\
\hline $\begin{array}{l}\text { Villa Pisani, Bagnolo (1542): } \\
\text { portico }\end{array}$ & 2.oft $\left(2^{\prime} \mathrm{o}^{\prime \prime}\right)$ & $17.85 \mathrm{ft}\left(17^{\prime} 10 ?^{\prime \prime}\right)$ & $1: 8.93$ \\
\hline $\begin{array}{l}\text { Villa Thiene, Quinto (c.1542/3): } \\
\text { façade }\end{array}$ & $2.42 \mathrm{ft}\left(2^{\prime} 5^{\prime \prime}\right)$ & $21.75 \mathrm{ft}\left(21^{\prime} 9^{\prime \prime}\right)$ & 1:9.00 \\
\hline $\begin{array}{l}\text { Palazzo Porto Festa (Vicenza (c.1546) } \\
\text { androne }\end{array}$ & $1.56 \mathrm{ft}\left(1^{\prime} 63 / 4^{\prime \prime}\right)$ & $11.65 \mathrm{ft}\left(11^{\prime} 7^{3 / 4^{\prime \prime}}\right)$ & $1: 7.45$ \\
\hline $\begin{array}{l}\text { Basilica, Vicenza (1546-49): } \\
\text { exterior (lower: large) }\end{array}$ & $2.47 \mathrm{ft}\left(2^{\prime}, 5 / 8^{\prime \prime}\right)$ & $19.54 \mathrm{ft}\left(19^{\prime} 61 / 2^{\prime \prime}\right)$ & $1: 7.91$ \\
\hline $\begin{array}{l}\text { exterior (lower: small) } \\
\text { Villa Angaran. Bassano del Grappa (154 }\end{array}$ & $1.44 \mathrm{ft}\left(1^{\prime} 5^{1 / 4^{\prime \prime}}\right)$ & $11.33 \mathrm{ft}\left(11^{\prime} 4^{\prime \prime}\right)$ & $1: 7.88$ \\
\hline $\begin{array}{c}\text { barn } \\
\text { Palazzo Chiericati, Vicenza (1550): }\end{array}$ & $2.00 \mathrm{ft}\left(2^{\prime} \mathrm{o}^{\prime \prime}\right)$ & $14.58 \mathrm{ft}\left(14^{\prime} 7^{\prime \prime}\right)$ & $1: 7.29$ \\
\hline façade (lower) & $2.50 \mathrm{ft}\left(2^{\prime} 6^{\prime \prime}\right)$ & $18.7^{1 \mathrm{ft}}\left(18^{\prime} 81^{1 / 2^{\prime \prime}}\right)$ & $1: 7 \cdot 48$ \\
\hline $\begin{array}{r}\text { Villa Pisani, Montagnana (c. 1552): } \\
\text { façade/portico (lower) }\end{array}$ & $2.25 \mathrm{ft}$ & 17.541 & \\
\hline androne & $1.75 \mathrm{ft}\left(1^{\prime} 9^{\prime \prime}\right)$ & $12.73 \mathrm{ft}\left(12^{\prime} 8^{3} / 4^{\prime \prime}\right)$ & $\begin{array}{l}1: 7.80 \\
1: 7.27\end{array}$ \\
\hline Villa Emo, Fanzolo (c. 1555): & & & \\
\hline $\begin{array}{l}\text { portico } \\
\text { Villa Badoer, Fratta Polesine }(c .1555)\end{array}$ & $2.38 \mathrm{ft}\left(2^{\prime} 4^{1 / 22^{\prime \prime}}\right)$ & $19.33 \mathrm{ft}\left(19^{\prime} 4^{\prime \prime}\right)$ & $1: 8.14$ \\
\hline $\begin{array}{l}\text { barn } \\
\text { Villa Thiene, Cicogna (1556) }\end{array}$ & $1.83 \mathrm{ft}\left(1^{\prime} 10^{\prime \prime}\right)$ & $13 \cdot 75 \mathrm{ft}\left(13^{\prime} 9^{\prime \prime}\right)$ & $1: 7 \cdot 50$ \\
\hline $\begin{array}{l}\text { barn } \\
\text { S. Maria della Carità, Venice (1560) }\end{array}$ & 2.17ft $\left(2^{\prime} 2^{\prime \prime}\right)$ & $17.25 \mathrm{ft}\left(17^{\prime} 3^{\prime \prime}\right)$ & $1: 7.96$ \\
\hline vestibule & $1.63 \mathrm{ft}\left(1^{\prime} 7^{1 / 22^{\prime \prime}}\right)$ & $12.83 \mathrm{ft}\left(12^{\prime} 10^{\prime \prime}\right)$ & $1: 7.90$ \\
\hline courtyard (bottom storey) & $2.15 \mathrm{ft}\left(2^{\prime} 1^{3 / 4^{\prime \prime}}\right)$ & $17 \cdot 38 \mathrm{ft}\left(17^{\prime} 4^{1 / 2 \prime}\right)$ & $1: 8.10$ \\
\hline $\begin{array}{l}\text { Loggia del Capitaniato, Vicenza (1565) } \\
\text { interior }\end{array}$ & $2.04 \mathrm{ft}\left(2^{\prime} \mathrm{O}^{1 / 2} 2^{\prime \prime}\right)$ & $1^{1 / 2}$ & \\
\hline Ionic orders & & & $1: 6.92$ \\
\hline $\begin{array}{c}\text { Palazzo Porto Festa, Vicenza (c.1546) } \\
\text { façade (upper) }\end{array}$ & $2.04 \mathrm{ft}\left(2^{\prime} \mathrm{o} 1 / 2^{\prime \prime}\right)$ & $17.88 \mathrm{ft}\left(17^{\prime} 10^{1 / 22^{\prime \prime}}\right)$ & $1: 8.75$ \\
\hline
\end{tabular}


TABLE 2: (continued)

\begin{tabular}{|c|c|c|c|}
\hline & Diameter/width & Height & Ratio \\
\hline \multicolumn{4}{|l|}{ Basilica, Vicenza (1546-49) } \\
\hline exterior (upper: large) & $2.00 \mathrm{ft}\left(2^{\prime} \mathrm{o}^{\prime \prime}\right)$ & $17 \cdot 50 \mathrm{ft}\left(17^{\prime} 6^{\prime \prime}\right)$ & $1: 8.75$ \\
\hline exterior (upper: small) & $1.22 \mathrm{ft}\left(1^{\prime} 2^{5 / 8^{\prime \prime}}\right)$ & $9.79 \mathrm{ft}\left(9^{\prime} 9^{1 / 2^{\prime \prime}}\right)$ & $1: 8.03$ \\
\hline \multicolumn{4}{|l|}{ Palazzo Chiericati, Vicenza (1550) } \\
\hline façade (upper) & $2.04 \mathrm{ft}\left(2^{\prime} \mathrm{o}^{1 / 2} 2^{\prime \prime}\right)$ & $18.17 \mathrm{ft}\left(18^{\prime} 2^{\prime \prime}\right)$ & $1: 8.90$ \\
\hline \multicolumn{4}{|l|}{ Villa Chiericati, Vancimuglio (1550/55) } \\
\hline portico & $2.54 \mathrm{ft}\left(2^{\prime} 61 / 2^{\prime \prime}\right)$ & $24.67 \mathrm{ft}\left(24^{\prime} 8^{\prime \prime}\right)$ & $1: 9.70$ \\
\hline \multicolumn{4}{|l|}{ Villa Pisani, Montagnana (c.1552) } \\
\hline façade/portico (upper) & $1.78 \mathrm{ft}\left(\mathrm{I}^{\prime} 9^{3 / 8^{\prime \prime}}\right)$ & $16.50 \mathrm{ft}\left(16^{\prime} 6^{\prime \prime}\right)$ & $1: 9.26$ \\
\hline \multicolumn{4}{|l|}{ Villa Cornaro, Piombino Dese (1552) } \\
\hline façade/portico (lower) & $1.96 \mathrm{ft}\left(1^{\prime} 11^{1 / 2^{\prime \prime}}\right)$ & $17 \cdot 71 \mathrm{ft}\left(17^{\prime} 81 / 2{ }^{\prime \prime}\right)$ & $1: 9.04$ \\
\hline \multicolumn{4}{|l|}{ Villa Barbaro, Maser (c.1554) } \\
\hline façade (giant) & $2.29 \mathrm{ft}\left(2^{\prime} 3^{1 / 2 \prime \prime}\right)$ & $22.21 \mathrm{ft}\left(22^{\prime} 2^{1 / 2} 2^{\prime \prime}\right)$ & $1: 9.69$ \\
\hline \multicolumn{4}{|l|}{ Villa Foscari, Malcontenta (1554) } \\
\hline $\begin{array}{l}\text { portico } \\
\text { Villa Badoer, Fratta Polesine (c. 1555) }\end{array}$ & $2.00\left(2^{\prime} 0^{\prime \prime}\right)$ & $17.92 \mathrm{ft}\left(17^{\prime} 11^{\prime \prime}\right)$ & $1: 8.96$ \\
\hline portico & $2.00 \mathrm{ft}\left(2^{\prime} \mathrm{o}^{\prime \prime}\right)$ & $19.50 \mathrm{ft}\left(19^{\prime} 6^{\prime \prime}\right)$ & $1: 9.75$ \\
\hline \multicolumn{4}{|l|}{ Palazzo Della Torre, Verona (c. 1555) } \\
\hline courtyard (lower) & $2.10 \mathrm{ft}\left(2^{\prime} 1^{1 / 4^{\prime \prime}}\right)$ & $18.25 \mathrm{ft}\left(18^{\prime} 3^{\prime \prime}\right)$ & $1: 8.67$ \\
\hline \multicolumn{4}{|l|}{ Palazzo Antonini, Udine (c.1556) } \\
\hline façade (lower)/androne & $1.90 \mathrm{ft}\left(1^{\prime} 10^{3 / 4^{\prime \prime}}\right)$ & $18.17 \mathrm{ft}\left(18^{\prime} 2^{\prime \prime}\right)$ & $1: 9.58$ \\
\hline \multicolumn{4}{|l|}{ Casa Cogolo, Vicenza (1559) } \\
\hline $\begin{array}{l}\text { façade (lower) } \\
\text { (n) }\end{array}$ & $1.56 \mathrm{ft}\left(1^{\prime} 634^{\prime \prime}\right)$ & $13.71 \mathrm{ft}\left(13^{\prime} 81_{2}^{\prime \prime}\right)$ & $1: 8.77$ \\
\hline \multicolumn{4}{|l|}{ S. Maria della Carità, Venice (1560) } \\
\hline \multicolumn{4}{|l|}{ Villa Mocenigo, Marocco (c. 156o; dem.) } \\
\hline portico (lower) & 2.ooft $\left(2^{\prime} \mathrm{o}^{\prime \prime}\right)$ & $18.08 \mathrm{ft}\left(18^{\prime} 1^{\prime \prime}\right)$ & $1: 9.04$ \\
\hline \multicolumn{4}{|l|}{ Villa Sarego, Miega (1562; dem;) } \\
\hline portico (lower) & $2.04 \mathrm{ft}\left(2^{\prime} 0^{1 / 2} 2^{\prime \prime}\right)$ & $17 \cdot 54 \mathrm{ft}\left(17^{\prime} 61 / 2{ }^{\prime \prime}\right)$ & 1:8.59 \\
\hline \multicolumn{4}{|l|}{ Villa Valmarana, Lisiera (c.1563) } \\
\hline portico (lower) & $2.08 \mathrm{ft}\left(2^{\prime} 1^{\prime \prime}\right)$ & $17.08 \mathrm{ft}\left(17^{\prime} 1^{\prime \prime}\right)$ & $1: 8.20$ \\
\hline \multicolumn{4}{|l|}{ Palazzo Valmarana, Vicenza (1565) } \\
\hline courtyard (lower) & $2.31 \mathrm{ft}\left(2^{\prime} 3^{3 / 4^{\prime \prime}}\right)$ & $19.29 \mathrm{ft}\left(19^{\prime} 3^{1 / 2}\right)$ & $1: 8.34$ \\
\hline \multicolumn{4}{|l|}{ Villa Sarego, S. Sofia (1565) } \\
\hline courtyard (giant) & $2.50 \mathrm{ft}\left(2^{\prime} 6^{\prime \prime}\right)$ & $24.33 \mathrm{ft}\left(24^{\prime} 4^{\prime \prime}\right)$ & $1: 9.73$ \\
\hline \multicolumn{4}{|l|}{ Villa Rotunda, Vicenza $(1566 / 67)$} \\
\hline portico & $2.04 \mathrm{ft}\left(2^{\prime} \mathrm{o}^{1 / 2 \prime 2}\right)$ & $18.13 \mathrm{ft}\left(18^{\prime} 11^{1 / 2}\right)$ & $1: 8.76$ \\
\hline \multicolumn{4}{|l|}{ Palazzo Barbaran, Vicenza (1569) } \\
\hline façade (lower) & $2.15 \mathrm{ft}\left(2^{\prime} 1^{3 / 4^{\prime \prime}}\right)$ & $19.21 \mathrm{ft}\left(19^{\prime} 2^{1 / 2^{\prime \prime}}\right)$ & 1:8.95 \\
\hline androne & $1.81 \mathrm{ft}\left(1^{\prime} 9^{3 / 4^{\prime \prime}}\right)$ & $15.54 \mathrm{ft}\left(15^{\prime} 61 / 2^{\prime \prime}\right)$ & $1: 8.57$ \\
\hline courtyard (lower) & $2.20 \mathrm{ft}\left(2^{\prime} 2^{3 / 8^{\prime \prime}}\right)$ & $20.13 \mathrm{ft}\left(20^{\prime} 1^{1 / 2} 2^{\prime \prime}\right)$ & $1: 9.16$ \\
\hline \multicolumn{4}{|l|}{ Corinthian orders } \\
\hline \multicolumn{4}{|l|}{ Casa Civena, Vicenza (1540) } \\
\hline Villa Cornaro, Piombino Dese (1552) & & & \\
\hline façade/portico (upper) & $1.60 \mathrm{ft}\left(1^{\prime} 7^{1 / 4^{\prime \prime}}\right)$ & $16.31 \mathrm{ft}\left(16^{\prime} 3^{3 / 4^{\prime \prime}}\right)$ & $1: 10.17$ \\
\hline Palazzo Antonini, Udine (c. 1556) & & & \\
\hline façade (upper) & $1.59 \mathrm{ft}\left(\mathbf{1}^{\prime} 7^{1 / 8^{\prime \prime}}\right)$ & $15.67 \mathrm{ft}\left(15^{\prime} 8^{\prime \prime}\right)$ & $1: 9.83$ \\
\hline
\end{tabular}


TABLE 2: (continued)

\begin{tabular}{|c|c|c|c|}
\hline & Diameter/width & Height & Ratio \\
\hline \multicolumn{4}{|l|}{ S. Maria della Carità, Venice (1560) } \\
\hline courtyard (top) & $1.33 \mathrm{ft}\left(1^{\prime} 4^{\prime \prime}\right)$ & $12.42 \mathrm{ft}\left(12^{\prime} 5^{\prime \prime}\right)$ & $1: 9.32$ \\
\hline \multicolumn{4}{|l|}{ Villa Mocenigo, Marocco (c.156o; dem.) } \\
\hline portico (upper) & $1.7 \mathrm{ft}\left(\mathrm{I}^{\prime} 812^{\prime \prime}\right)$ & $16.25 \mathrm{ft}\left(16^{\prime} 3^{\prime \prime}\right)$ & $1: 9.51$ \\
\hline \multicolumn{4}{|l|}{ Villa Sarego, Miega (1562; dem.) } \\
\hline portico (upper) & $1.63 \mathrm{ft}\left(\mathrm{1}^{\prime} 7^{1 / 2^{\prime \prime}}\right)$ & $16.38 \mathrm{ft}\left(16^{\prime} 4^{1 / 22^{\prime \prime}}\right)$ & 1:10.08 \\
\hline \multicolumn{4}{|l|}{ S. Francesco della Vigna, Venice (1564) } \\
\hline façade (giant) & $4.00 \mathrm{ft}\left(4^{\prime} \mathrm{o}^{\prime \prime}\right)$ & $40.00 \mathrm{ft}\left(40^{\prime} \mathrm{o}^{\prime \prime}\right)$ & 1:10.0 \\
\hline façade (small) & $2.00 \mathrm{ft}\left(2^{\prime} \mathrm{o}^{\prime \prime}\right)$ & $20.17 \mathrm{ft}\left(20^{\prime} 2^{\prime \prime}\right)$ & 1:10.08 \\
\hline \multicolumn{4}{|l|}{ Palazzo Valmarana, Vicenza (1565) } \\
\hline façade (lower) & $1.38 \mathrm{ft}\left(1^{\prime} 4^{1 / 2^{\prime \prime}}\right)$ & 12.8 Ift $\left(12^{\prime} 9^{3 / 4^{\prime \prime}}\right)$ & 1:9.32 \\
\hline \multicolumn{4}{|l|}{ S. Giorgio Maggiore, Venice (1565) } \\
\hline interior (small) & $2.13 \mathrm{ft}\left(2^{\prime} 1^{1 / 22^{\prime \prime}}\right)$ & $21.08 \mathrm{ft}\left(21^{\prime} 1^{\prime \prime}\right)$ & 1:10.17 \\
\hline \multicolumn{4}{|l|}{ Palazzo Barbaran, Vicenza (1569) } \\
\hline façade (upper) & $1.75 \mathrm{ft}\left(1^{\prime} 9^{\prime \prime}\right)$ & $16.73 \mathrm{ft}\left(16^{\prime} 834^{\prime \prime}\right)$ & $1: 9.56$ \\
\hline courtyard (upper) & $1.78 \mathrm{ft}\left(1^{\prime} 9^{5 / 16^{\prime \prime}}\right)$ & $16.63 \mathrm{ft}\left(16^{\prime} 7^{1 / 22^{\prime \prime}}\right)$ & $1: 9.36$ \\
\hline \multicolumn{4}{|l|}{ Palazzo Porto Breganze, Vicenza (1571) } \\
\hline courtyard (lower) & $1.92 \mathrm{ft}\left(\mathrm{I}^{\prime} 1 \mathrm{I}^{\prime \prime}\right)$ & $19.46 \mathrm{ft}\left(19^{\prime} 5^{1 / 2}\right)$ & $1: 10.15$ \\
\hline \multicolumn{4}{|l|}{ Redentore, Venice (1576) } \\
\hline façade (small) & $2.67 \mathrm{ft}\left(2^{\prime} 8^{\prime \prime}\right)$ & $28.83 \mathrm{ft}\left(26^{\prime} 10^{\prime \prime}\right)$ & 1:10.08 \\
\hline interior (giant) & $3.17 \mathrm{ft}\left(3^{\prime} 2^{\prime \prime}\right)$ & $32.50 \mathrm{ft}\left(32^{\prime} 6^{\prime \prime}\right)$ & $1: 10.26$ \\
\hline interior (small) & $1.96 \mathrm{ft}\left(1^{\prime} 11^{\prime 1 / 2 \prime}\right)$ & $19.83 \mathrm{ft}\left(19^{\prime} 10^{\prime \prime}\right)$ & 1.10 .13 \\
\hline \multicolumn{4}{|l|}{ Tempietto, Maser (1580) } \\
\hline portico & $2.00 \mathrm{ft}\left(2^{\prime} \mathrm{o}^{\prime \prime}\right)$ & $19 \cdot 54 \mathrm{ft}\left(19^{\prime} 612^{\prime \prime}\right)$ & $1: 9.77$ \\
\hline interior & $2.04 \mathrm{ft}\left(2^{\prime} \mathrm{O}^{1 / 22^{\prime \prime}}\right)$ & $19.96 \mathrm{ft}\left(19^{\prime} 11^{1 / 2 \prime}{ }^{\prime \prime}\right)$ & $1: 9.77$ \\
\hline \multicolumn{4}{|l|}{ Teatro Olimpico, Vicenza (1580) } \\
\hline scene (lower) & $1.27 \mathrm{ft}\left(\mathrm{I}^{\prime} 3^{1 / 4^{\prime \prime}}\right)$ & $12.02 \mathrm{ft}\left(12^{\prime} 0^{1} 2^{\prime \prime}\right)$ & $1: 9.46$ \\
\hline scene (upper) & $1.02 \mathrm{ft}\left(I^{\prime} 0^{1 / 4^{\prime \prime}}\right)$ & $9.73 \mathrm{ft}\left(9^{\prime} 834^{\prime \prime}\right)$ & $1: 9.53$ \\
\hline auditorium & $\left.1.13 \mathrm{ft}\left(1^{\prime} 1^{1 / 2 \prime}\right)^{\prime}\right)$ & $10.92 \mathrm{ft}\left(10^{\prime} 11^{\prime \prime}\right)$ & $1: 9.70$ \\
\hline \multicolumn{4}{|l|}{ Composite orders } \\
\hline \multicolumn{4}{|l|}{ Palazzo Thiene, Vicenza (1542) } \\
\hline exterior/courtyard & $2.00 \mathrm{ft}\left(2^{\prime} \mathrm{o}^{\prime \prime}\right)$ & $20.00 \mathrm{ft}\left(20^{\prime} \mathrm{o}^{\prime \prime}\right)$ & $1: 10.00$ \\
\hline \multicolumn{4}{|l|}{ Villa Gazzotti, Bertesina (1542) } \\
\hline exterior & $1.67 \mathrm{ft}\left(1^{\prime} 8^{\prime \prime}\right)$ & $16.73 \mathrm{ft}\left(16^{\prime} 83 / 4^{\prime \prime}\right)$ & $1: 10.04$ \\
\hline \multicolumn{4}{|l|}{ Palazzo Valmarana, Vicenza (1565) } \\
\hline façade (giant) & $2.76 \mathrm{ft}\left(2^{\prime} 9^{1 / 8^{\prime \prime}}\right)$ & $28.39 \mathrm{ft}\left(28^{\prime} 4^{5 / 8^{\prime \prime}}\right)$ & $1: 10.28$ \\
\hline \multicolumn{4}{|l|}{ S. Giorgio Maggiore, Venice (1565) } \\
\hline interior (giant) & $2.88 \mathrm{ft}\left(2^{\prime} 10^{1 / 2} 2^{\prime \prime}\right)$ & $29.25 \mathrm{ft}\left(29^{\prime} 3^{\prime \prime}\right)$ & $1: 10.17$ \\
\hline \multicolumn{4}{|l|}{ Loggia del Capitaniato, Vicenza (1565) } \\
\hline façade (giant) & $3.25 \mathrm{ft}\left(3^{\prime} 3^{\prime \prime}\right)$ & $33.52 \mathrm{ft}\left(33^{\prime} 61^{1 / 4^{\prime \prime}}\right)$ & $1: 10.31$ \\
\hline side (smaller) & $2.00 \mathrm{ft}\left(2^{\prime} \mathrm{o}^{\prime \prime}\right)$ & $20.46 \mathrm{ft}\left(20^{\prime} 5^{1 / 2} 2^{\prime \prime}\right)$ & $1: 10.23$ \\
\hline \multicolumn{4}{|l|}{ Palazzo Porto Breganze, Vicenza (1571) } \\
\hline façade (giant) & $2.98 \mathrm{ft}\left(2^{\prime} 11^{3 / 4^{\prime \prime}}\right)$ & $29.75 \mathrm{ft}\left(29^{\prime} 9^{\prime \prime}\right)$ & $1: 9.99$ \\
\hline \multicolumn{4}{|l|}{ Redentore, Venice (1576) } \\
\hline façade (giant) & $3.80 \mathrm{ft}\left(3^{\prime} 9^{5 / 8^{\prime \prime}}\right)$ & $38.75 \mathrm{ft}\left(38^{\prime} 10^{\prime \prime}\right)$ & 1:10.19 \\
\hline
\end{tabular}


TABLE 3: Temples illustrated in the Quattro libri

Measurements in feet (for further information, see n. 153)

\begin{tabular}{llll}
\hline & Diameter/width & Height & Ratio \\
\hline
\end{tabular}

Bk 4, Pp. I1-14: Basilica of Maxentius ('Temple of Peace'), Rome

$\begin{array}{clcc}\text { Corinthian: porch } & 2.63 \mathrm{ft}\left(2^{\prime} 7^{1 / 2 \prime}\right) & 26 \mathrm{ft} & 1: 9.9 \\ \text { Corinthian: interior } & 5.33 \mathrm{ft}\left(5^{\prime} 4^{\prime \prime}\right) & 53 \mathrm{ft} & 1: 9.9 \\ \begin{array}{c}\text { alternatively (p. 12): } \\ \text { 15-22: Temple of Mars Ultor, Rome }\end{array} & 5.00 \mathrm{ft}\left(5^{\prime} 0^{\prime \prime}\right) & & 1: 10.6 \\ \text { Corinthian: portico } & 4.92 \mathrm{ft}\left(4^{\prime} 11^{\prime \prime}\right) & 48 \mathrm{ft} & \\ \text { Figurated: interior } & 2.25 \mathrm{ft}\left(2^{\prime} 4^{\prime \prime}\right) & 24 \mathrm{ft} & 1: 9.8\end{array}$

Bk 4, pp. 23-29: Temple of Minerva ('Temple of Nerva'), Rome

$\begin{array}{llll}\text { Corinthian: portico } & 4.08 \mathrm{ft}\left(4^{\prime} 1^{\prime \prime}\right) & 40 \mathrm{ft} & 1: 9.8 \\ \text { Corinthian: interior } & 1.50 \mathrm{ft}\left(1^{\prime} 6^{\prime \prime}\right) & 15 \mathrm{ft} & 1: 10.0 \\ \text { Corinthian: forecourt } & 3.17 \mathrm{ft}\left(3^{\prime} 2^{\prime \prime}\right) & 32 \mathrm{ft} & 1: 10.1\end{array}$

Bk 4. pp. 30-35: Temple of Antoninus and Faustina, Rome

$\begin{array}{llcl}\text { Corinthian: portico } & 4.08 \mathrm{ft}\left(4^{\prime} 1^{\prime \prime}\right) & 39 \mathrm{ft} & 1: 9.6 \\ \text { Corinthian: forecourt } & 3.00 \mathrm{ft}\left(3^{\prime} \mathrm{o}^{\prime \prime}\right) & 30 \mathrm{ft} & 1: 10.0 \\ 36-39: \text { Temple of Venus and Rome } & (T e m p l e \text { of the Sun and Moon'), Rome } & \\ \text { Corinthian: porch } & 2.50 \mathrm{ft}\left(2^{\prime} 6^{\prime \prime}\right) & 24 \mathrm{ft} & 1: 9.6 \\ \text { Corinthian: interior } & 1.50 \mathrm{ft}\left(1^{\prime} 6^{\prime \prime}\right) & 15 \mathrm{ft} & 1: 10.0\end{array}$

Bk 4, pp. 41-47: Temple of Serapis ('Temple of Jupiter'), Rome

Corinthian: portico and perimeter $5.50 \mathrm{ft}\left(5^{\prime \prime} 6^{\prime \prime}\right) \quad$ unspecified

Ionic: interior (lower)

$\begin{array}{lll}3.25 \mathrm{ft}\left(3^{\prime} 3^{\prime \prime}\right) & 30 \mathrm{ft} & 1: 9.2 \\ 2.50 \mathrm{ft}\left(2^{\prime} 6^{\prime \prime}\right) & 25 \mathrm{ft} & 1: 10.0 \\ 1.63 \mathrm{ft}\left(1^{\prime} 7^{1 / 2}\right) & 16 \mathrm{ft} & 1: 9.8\end{array}$

Corinthian: side courtyards $\left.\quad 1.63 \mathrm{ft}\left(1^{\prime} 7^{1 / 2}\right)^{\prime \prime}\right) \quad 16 \mathrm{ft}$

Bk 4, pp. 48-51: Temple of Portumnus ('Temple of Fortuna Virilis'), Rome
Ionic: portico and perimeter $2.71 \mathrm{ft}\left(2^{\prime} 88^{1 / 2}{ }^{\prime \prime}\right)$

Bk 4, pp. 52-54: Round temple by the Tiber ('Temple of Vesta'), Rome
Corinthian: perimeter
$2.50 \mathrm{ft}\left(2^{\prime} 6^{\prime \prime}\right)$
$28 \mathrm{ft}$
$1: 11.2$

Bk 4, pp. 55-60: Temple of Hadrian ('Temple of Mars'), Rome

Corinthian: portico and perimeter $\quad 4.17 \mathrm{ft}\left(4^{\prime} 2^{\prime \prime}\right)$

$4.17 \mathrm{ft}\left(4^{\prime} 2^{\prime \prime}\right) \quad 41 \mathrm{ft}$

$1: 9.8$ alternatively (p. 57):

Corinthian: interior

$1: 9.6$

1:10.1

Bk 4, pp. 61-63: Lateran Baptistery ('Baptistery of Constantine'), Rome

Composite: porch and interior

Unstated: interior (upper)

Bk 4, pp. 64-66: Bramante's Tempietto, Rome

Doric: perimeter

$$
\begin{aligned}
& 2.00 \mathrm{ft}\left(2^{\prime} 0^{\prime \prime}\right) \\
& 1.50 \mathrm{ft}\left(1^{\prime} 6^{\prime \prime}\right)
\end{aligned}
$$

$40 \mathrm{ft}$

$26 \mathrm{ft}$

$18 \mathrm{ft}$

$13.50 \mathrm{ft}\left(13^{\prime} 6^{\prime \prime}\right)$

1:9.0

1:9.0

$1.09 \mathrm{ft}\left(1^{\prime} 4^{1 / 2} \mathrm{~min}\right.$.) $\quad 10 \mathrm{ft}$

1:9.1

Bk 4, pp. 67-69: Temple of Castor ('Temple of Jupiter Stator'), Rome

Corinthian: portico and perimeter

Bk 4, pp. 73-84: Pantheon, Rome

Corinthian: portico

Corinthian: interior (lower)

Corinthian: interior (upper)

Corinthian: interior tabernacles
$4.04 \mathrm{ft}\left(4^{\prime} 2 \mathrm{~min}\right.$. $) \quad 40 \mathrm{ft}$

1:9.9

$4.04 \mathrm{ft}\left(4^{\prime} 2 \mathrm{~min}\right.$.)

$3.18 \mathrm{ft}\left(3^{\prime} 2^{1 / 2} 2^{\prime \prime}\right)$

$40.25 \mathrm{ft}\left(4 \mathrm{o}^{\prime} 3^{\prime \prime}\right)$

$1: 9.9$

$1.25 \mathrm{ft}\left(1^{\prime} 3^{\prime \prime}\right)$

$1.25 \mathrm{ft}\left(1^{\prime} 3^{\prime \prime}\right)$

$30.42 \mathrm{ft}\left(30^{\prime} 5^{\prime \prime}\right)$

$1: 9.6$

$12.50 \mathrm{ft}\left(12^{\prime} 6^{\prime \prime}\right) \quad 1: 10.0$

12.50ft (12' 6") 1:10.0 
TABLE 3: (continued)

\begin{tabular}{|c|c|c|c|}
\hline & Diameter/width & Height & Ratio \\
\hline \multicolumn{4}{|c|}{ Bk 4, pp. 85-87: S. Costanza ('Temple of Bacchus'), Rome } \\
\hline Composite: interior & $1.25^{\prime}\left(1^{\prime} 3^{\prime \prime}\right)$ & $11.83 \mathrm{ft}\left(11^{\prime}-10^{\prime \prime}\right)$ & $1: 9.5$ \\
\hline \multicolumn{4}{|c|}{ Bk 4, pp. 90-94: Round Temple ('Temple of Vesta'), Tivoli } \\
\hline Corinthian: perimeter & $2.09 \mathrm{ft}\left(2^{\prime} 4^{1 / 4 \mathrm{~min}}.\right)$ & $20 \mathrm{ft}$ & 1:9.6 \\
\hline \multicolumn{4}{|c|}{ Bk 4, pp. 95-97: Temple of Castor and Pollux, Naples } \\
\hline Corinthian: portico & $3.31 \mathrm{ft}\left(3^{\prime} 3^{3 / 4}{ }^{\prime \prime}\right)$ & $33.17 \mathrm{ft}\left(33^{\prime} 2^{\prime \prime}\right)$ & 1:10.0 \\
\hline \multicolumn{4}{|c|}{ Bk 4, pp. 98-102: Tempietto di Clitunno ('Temple below Trevi'), nr Spoleto } \\
\hline Corinthian: portico & $1.17 \mathrm{ft}\left(1^{\prime} 2^{\prime \prime}\right)$ & $11 \mathrm{ft}$ & $1: 9.4$ \\
\hline Corinthian: side porch & $0.63 \mathrm{ft}\left(\mathrm{o}^{\prime} 7^{\prime \prime}\right)$ & $6 \mathrm{ft}$ & 1:9.7 \\
\hline \multicolumn{4}{|l|}{ Bk 4,pp. 103-06: Temple of Minerva, Assisi } \\
\hline Corinthian: portico & $2.83 \mathrm{ft}\left(2^{\prime} 10^{\prime \prime}\right)$ & $27.25 \mathrm{ft}\left(27^{\prime} 3^{\prime \prime}\right)$ & $1: 9.6$ \\
\hline \multicolumn{4}{|c|}{ Bk 4, pp. 107-10: Temple of Augustus and Rome, Pula } \\
\hline Corinthian: portico & $2.25 \mathrm{ft}\left(2^{\prime} 3^{\prime \prime}\right)$ & $22.50 \mathrm{ft}\left(20^{\prime} 6^{\prime \prime}\right)$ & $1: 10.0$ \\
\hline Bk 4, pp. 111-17: 'Maison Carrée', Nîmes & & & \\
\hline $\begin{array}{l}\text { Corinthian: portico and perimeter } \\
\text { Bk 4,pp. 118-23: Nymphaeum, Nîmes }\end{array}$ & $2.75 \mathrm{ft}\left(2^{\prime} 9^{\prime \prime}\right)$ & $27.50 \mathrm{ft}\left(27^{\prime} 6^{\prime \prime}\right)$ & 1:10.0 \\
\hline Composite: interior & $1.54 \mathrm{ft}\left(\mathrm{I}^{\prime} 61_{2}^{\prime \prime}\right)$ & $14 \cdot 71 \mathrm{ft}\left(14^{\prime} 812^{\prime \prime}\right)$ & $x: 9.6$ \\
\hline \multicolumn{4}{|c|}{ Bk 4, pp. 124-27: Temple of Saturn ('Temple of Concord'), Rome } \\
\hline Ionic: portico and perimeter & $3.75 \mathrm{ft}\left(3^{\prime} 9^{\prime \prime}\right)$ & $33.75 \mathrm{ft}\left(33^{\prime} 9^{\prime \prime}\right)$ & 1:9.0 \\
\hline \multicolumn{4}{|c|}{ Bk 4, pp. 128-33: Temple of Venus Genetrix ('Temple of Neptune'), Rome } \\
\hline Corinthian: portico and perimeter & $3.75 \mathrm{ft}\left(3^{\prime} 9^{\prime \prime}\right)$ & $38 \mathrm{ft}$ & 1:10.1 \\
\hline
\end{tabular}


TABle 4: Palladio schemes represented in the Quattro libri

Measurements in feet (for further information, see n. 153)

Diameter/width Height $\quad$ Ratio $\begin{gathered}\text { Actual } \\ \text { (as Table 2) }\end{gathered}$

Bk 2, pp. 4-5: Palazzo Antonini, Udine

Ionic: façade (lower)

2.00 ft $\left(2^{\prime} \mathrm{O}^{\prime \prime}\right) \quad 19.00 \mathrm{ft}\left(19^{\prime} \mathrm{o}^{\prime \prime}\right)$

1:9.50

1:9.58

Corinthian: facade (upper)

$1.63 \mathrm{ft}\left(\mathrm{I}^{\prime} 7^{1 / 2} 2^{\prime \prime}\right)$

$16.00 \mathrm{ft}\left(16^{\prime} \mathrm{o}^{\prime \prime}\right)$

1:9.82

$1: 9.83$

Bk 2, pp. 6-7: Palazzo Chiericati, Vicenza
Doric: façade (lower)
Ionic: façade (upper)
$2.50 \mathrm{ft}\left(2^{\prime} 6^{\prime \prime}\right)$
2.0oft $\left(2^{\prime} \mathrm{O}^{\prime \prime}\right)$

alternatively (p. 6):

20.0oft $\left(20^{\prime} \mathrm{o}^{\prime \prime}\right)$

$\mathbf{x}: 8.00$

$1: 7.48$

$18.00 \mathrm{ft}\left(18^{\prime} \mathrm{o}^{\prime \prime}\right)$

1:9.00

$1: 8.90$

$17.00 \mathrm{ft}\left(17^{\prime} \mathrm{o}^{\prime \prime}\right)$

$1: 8.50$

Bk 2, pp. 8-10: Palazzo Porto Festa, Vicenza
Ionic (in reality Doric): androne
Ionic: façade (upper)
$1.75 \mathrm{ft}\left(1^{\prime} 9^{\prime \prime}\right)$
$2.00 \mathrm{ft}\left(2^{\prime} \mathrm{o}^{\prime \prime}\right)$
Composite: courtyard (giant)
$3.50 \mathrm{ft}\left(3^{\prime} 6^{\prime \prime}\right)$

$15.00 \mathrm{ft}\left(15^{\prime} \mathrm{o}^{\prime \prime}\right)$

1:8.57

1.7 .45

$19.00 \mathrm{ft}\left(18^{\prime} \mathrm{o}^{\prime \prime}\right)$

1:9.00

1.8 .75

Bk 2, p. 11: Palazzo della Torre, Verona
Ionic: courtyard (lower)
$2.13 \mathrm{ft}\left(2^{\prime} 1^{1 / 2}{ }^{\prime \prime}\right)$

$35.00 \mathrm{ft}\left(35^{\prime} \mathrm{o}^{\prime \prime}\right)$

1:10.00

24.0oft $\left(24^{\prime} \mathrm{O}^{\prime \prime}\right)$ : error [1:11.27] 1:8.67

Bk 2, pp. 12-15: Palazzo Thiene, Vicenza
Composite: façade (upper)
$2.00 \mathrm{ft}\left(2^{\prime} \mathrm{O}^{\prime \prime}\right)$
Composite: courtyard (upper)
$2.00 \mathrm{ft}\left(2^{\prime} \mathrm{o}^{\prime \prime}\right)$

$20.00 \mathrm{ft}\left(2 \mathrm{O}^{\prime} \mathrm{o}^{\prime \prime}\right)$

1:10.00

1:10.00

$20.00 \mathrm{ft}\left(2 \mathrm{O}^{\prime} \mathrm{o}^{\prime \prime}\right)$

1:10.00

1:10.00

Bk 2, pp. 16-17: Palazzo Valmarana, Vicenza
Corinthian: façade (small)
Composite: façade (giant)
Bk 2, pp. 18-19: Villa Rotunda, Vicenza
Ionic: portico

$1.50 \mathrm{ft}\left(1^{\prime \prime} 6^{\prime \prime}\right)$

$14.00 \mathrm{ft}\left(14^{\prime} \mathrm{O}^{\prime \prime}\right)$

$2.85 \mathrm{ft}\left(2^{\prime} 10^{1 / 4^{\prime \prime}}\right)$

$28.75 \mathrm{ft}\left(28^{\prime} 9^{\prime \prime}\right)$

$1: 9.33$

1:10.09

1:9.32

[2.0oft: presumed] $18.00 \mathrm{ft}\left(18^{\prime} \mathrm{o}^{\prime \prime}\right)$

1:9.00

I:10.28

Bk 2, pp. 22-23: Palazzo Barbaran, Vicenza
Ionic: façade (lower)
$2.13 \mathrm{ft}\left(2^{\prime} 11^{1 / 2 \prime}\right)$

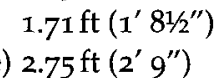
Corinthian: façade (upper)
Composite: façade (giant: alternative)

$19.00 \mathrm{ft}\left(19^{\prime} \mathrm{o}^{\prime \prime}\right)$

$16.50 \mathrm{ft}\left(16^{\prime} 6^{\prime \prime}\right)$

28.0oft $\left(28^{\prime} \mathrm{o}^{\prime \prime}\right)$

$1: 8.76$

Bk 2, pp. 29-32: S. Maria della Carità, Venice

\begin{abstract}
Doric: courtyard (bottom)
Ionic: courtyard (middle)

Corinthian: courtyard (top)

Composite: atrium (giant)
\end{abstract}

Bk 2, p. 47: Villa Pisani, Bagnolo

Doric: colonnade

Bk 2, p. 48: Villa Badoer, Fratta Polesine

Doric (baseless): colonnade

Ionic: portico

Bk 2, p. 49: Villa Zen, Cessalto

Doric (baseless): colonnade

$$
\begin{aligned}
& 2.25 \mathrm{ft}\left(2^{\prime} 3^{\prime \prime}\right) \\
& 1.83 \mathrm{ft}\left(1^{\prime} 10^{\prime \prime}\right) \\
& 1.50 \mathrm{ft}\left(1^{\prime} 6^{\prime \prime}\right) \\
& 3.50 \mathrm{ft}\left(3^{\prime} 6^{\prime \prime}\right)
\end{aligned}
$$$$
2.50 \mathrm{ft}\left(2^{\prime} 6^{\prime \prime}\right)
$$

$2.00 \mathrm{ft}\left(2^{\prime} \mathrm{O}^{\prime \prime}\right)$

$2.13 \mathrm{ft}\left(2^{\prime} 1^{1} 2^{\prime \prime}\right)$

$2.00 \mathrm{ft}\left(2^{\prime} \mathrm{o}^{\prime \prime}\right)$
$18.00 \mathrm{ft}\left(18^{\prime} \mathrm{o}^{\prime \prime}\right)$

$16.00 \mathrm{ft}\left(16^{\prime} \mathrm{o}^{\prime \prime}\right)$

$14.00 \mathrm{ft}\left(14^{\prime} \mathrm{o}^{\prime \prime}\right)$

$35.00 \mathrm{ft}\left(35^{\prime} \mathrm{o}^{\prime \prime}\right)$

$19.00 \mathrm{ft}\left(19^{\prime} \mathrm{o}^{\prime \prime}\right)$

$14.00 \mathrm{ft}$ ( $\left.14^{\prime} \mathrm{o}^{\prime \prime}\right)$

$20.00 \mathrm{ft}\left(20^{\prime} \mathrm{O}^{\prime \prime}\right)$

$15.00 \mathrm{ft}\left(15^{\prime} \mathrm{o}^{\prime \prime}\right)$

1:7.50
1:8.92

1:9.65

1:10.18

$1: 7.60$

1:7.00

1:9.39

1:7.50

1:8.95 1:9.56

-

$1: 8.10$ 1:8.85

1:9.32

1:9.33

-

1:9.75 
TABLE 4 (continued)

Diameter/width Height Ratio

Actual

(as Table 2)

Bk 2, p. 5o: Villa Foscari, Malcontenta

Ionic: portico

Bk 2, p. 51: Villa Barbaro, Maser

$$
\text { Ionic: façade (giant) }
$$

Bk 2, p. 52: Villa Pisani, Montagnana
Doric: portico (lower)
Ionic: portico (upper)

$2.00 \mathrm{ft}\left(2^{\prime} \mathrm{O}^{\prime \prime}\right)$

$2.50 \mathrm{ft}\left(2^{\prime} 6^{\prime \prime}\right)$

$2.25 \mathrm{ft}\left(2^{\prime} 3^{\prime \prime}\right)$

$1.75 \mathrm{ft}\left(1^{\prime} 9^{\prime \prime}\right)$

Bk 2, p. 53: Villa Cornaro, Piombino Dese
Ionic: portico (lower)
Corinthian: portico (upper)

Bk 2, p. 54: Villa Mocenigo, Marocco

$$
\text { Ionic: portico (lower) }
$$$$
2.00 \mathrm{ft}\left(2^{\prime} 0^{\prime \prime}\right)
$$$$
1.63 \mathrm{ft}\left(1^{\prime} 7^{1 / 2^{\prime \prime}}\right)
$$$$
18.50 \mathrm{ft}\left(18^{\prime} 6^{\prime \prime}\right)
$$

$17.50 \mathrm{ft}\left(17^{\prime} 6^{\prime \prime}\right)$

$16.00 \mathrm{ft}\left(16^{\prime} \mathrm{o}^{\prime \prime}\right)$

$18.00 \mathrm{ft}\left(18^{\prime} \mathrm{o}^{\prime \prime}\right)$

$16.00 \mathrm{ft}\left(16^{\prime} \mathrm{o}^{\prime \prime}\right)$

$2.00 \mathrm{ft}\left(2^{\prime} \mathrm{o}^{\prime \prime}\right)$

$18.50 \mathrm{ft}\left(18^{\prime} 6^{\prime \prime}\right)$

$2.50 \mathrm{ft}\left(2^{\prime} 6^{\prime \prime}\right)$

Doric: portico

Bk 2, p. 56: Villa Saraceno, Finale di Agugliaro

Doric (baseless): colonnade

2.0oft ( $\left.2^{\prime} o^{\prime \prime}\right)$

Bk 2, p. 57: Villa Ragona, Le Ghizzole

$15.00 \mathrm{ft}\left(15^{\prime} \mathrm{o}^{\prime \prime}\right)$

$25.00 \mathrm{ft}\left(25^{\prime} \mathrm{o}^{\prime \prime}\right)$
Doric: colonnade

Composite: portico (giant)

$2.00 \mathrm{ft}\left(2^{\prime} \mathrm{o}^{\prime \prime}\right)$

$2.50 \mathrm{ft}\left(2^{\prime} 6^{\prime \prime}\right)$

Bk 2, p. 58: Villa Poiana, Poiana Maggiore
Doric (baseless): colonnade
Doric: entrance

2.0oft $\left(2^{\prime} \mathrm{o}^{\prime \prime}\right)$

$2.00 \mathrm{ft}\left(2^{\prime} \mathrm{o}^{\prime \prime}\right)$

Bk 2, p. 59: Villa Valmarana, Lisiera

Ionic: portico (lower)

Corinthian: portico (upper)

Bk 2, p. 6o: Villa Trissino, Meledo

Tuscan: colonnade

?Ionic: colonnade

Corinthian: portico

Bk 2, p.61: Villa Repeta, Campiglia

Doric: colonnade

$$
2.00 \mathrm{ft}\left(2^{\prime} \mathrm{o}^{\prime \prime}\right)
$$

$1.58 \mathrm{ft}\left(\mathrm{1}^{\prime} 7^{\prime \prime}\right)$

$2.00 \mathrm{ft}\left(2^{\prime} \mathrm{o}^{\prime \prime}\right)$

2.0oft $\left(2^{\prime} \mathrm{o}^{\prime \prime}\right)$

2.50ft $\left(2^{\prime} 6^{\prime \prime}\right)$

$2.00 \mathrm{ft}\left(2^{\prime} \mathrm{o}^{\prime \prime}\right)$

$2.00 \mathrm{ft}\left(2^{\prime} \mathrm{o}^{\prime \prime}\right)$

$4.00 \mathrm{ft}\left(4^{\prime} \mathrm{o}^{\prime \prime}\right)$

[linking to extant Doric barn]

Composite: portico (giant)

Bk 2, p.63: Villa Angaran, Bassano del Grappa

Doric (baseless): colonnade

Composite: portico (giant)

Bk 2, p.64: Villa Thiene, Quinto

Doric: façade

$\begin{array}{llll}2.00 \mathrm{ft}\left(2^{\prime} \mathrm{o}^{\prime \prime}\right) & 15.00 \mathrm{ft}\left(15^{\prime} \mathrm{o}^{\prime \prime}\right) & 1: 7.50 & 1: 7.29 \\ 4.00 \mathrm{ft}\left(4^{\prime} \mathrm{o}^{\prime \prime}\right) & 40.00 \mathrm{ft}\left(16^{\prime} \mathrm{o}^{\prime \prime}\right) & 1: 10.00 & - \\ & & & \\ 2.50 \mathrm{ft}\left(2^{\prime} 6^{\prime \prime}\right) & 22.00 \mathrm{ft}\left(22^{\prime} \mathrm{o}^{\prime \prime}\right) & 1: 8.80 & 1: 9.00\end{array}$

9.00$$
22.50 \mathrm{ft}\left(22^{\prime} 6^{\prime \prime}\right)
$$

1:9.25 $1: 8.96$

1:9.00 $\quad 1: 9.69$

$1: 7.78 \quad 1: 7.80$

$1: 9.14 \quad 1: 9.26$

1:9.00 1:9.04

$1: 9.82 \quad 1: 10.17$

$1: 9.25 \quad 1: 9.04$

1:8.00 1:8.14

1:8.00

1:7.50

1:10.00

$15.00 \mathrm{ft}\left(15^{\prime} \mathrm{o}^{\prime \prime}\right)$

$1: 7.5^{\circ}$

$1: 8.00$

1:9.00

$1: 9.49$

$1: 8.20$

$15.00 \mathrm{ft}\left(15^{\prime} \mathrm{o}^{\prime \prime}\right)$

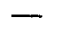

$15.00 \mathrm{ft}\left(15^{\prime} \mathrm{o}^{\prime \prime}\right)$

1:7.50

$18.50 \mathrm{ft}\left(18^{\prime} 6^{\prime \prime}\right)$

$25.00 \mathrm{ft}\left(25^{\prime} \mathrm{o}^{\prime \prime}\right)$

$1: 9.25$

1:10.00

$15.50 \mathrm{ft}\left(15^{\prime} 6^{\prime \prime}\right)$

1:7.75

$16.00 \mathrm{ft}\left(16^{\prime} \mathrm{o}^{\prime \prime}\right)$

1:8.00

$[1: 7.96]$

$40.00 \mathrm{ft}\left(16^{\prime} \mathrm{o}^{\prime \prime}\right)$

1:10.00

-

$-$

-

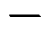


TABLE 4 (continued)

Diameter/width Height $\quad$ Ratio $\begin{gathered}\text { Actual } \\ \text { (as Table 2) }\end{gathered}$

Bk 2, pp. 66-67: Villa Sarego, S. Sofia Ionic: colonnade

$$
2.63 \mathrm{ft}\left(2^{\prime} 7^{1 / 2}\right) \quad 25.00 \mathrm{ft}\left(25^{\prime} \mathrm{o}^{\prime \prime}\right)
$$

$1: 9.51$

$1: 9.73$

Bk 2, p.68: Villa Sarego, Miega

$$
\begin{aligned}
& \text { Ionic: portico (lower) } \\
& \text { Corinthian: portico (upper) }
\end{aligned}
$$$$
\begin{aligned}
& 2.13 \mathrm{ft}\left(2^{\prime} 1^{1 / 2^{\prime \prime}}\right) \\
& ? 1.54 \mathrm{ft}\left(? 1^{\prime} 61^{\prime \prime}\right)
\end{aligned}
$$

$18.00 \mathrm{ft}\left(18^{\prime} \mathrm{o}^{\prime \prime}\right)$

$1: 8.45$

$1: 8.59$

$15.00 \mathrm{ft}\left(15^{\prime} \mathrm{o}^{\prime \prime}\right)$

$1: 9.74$

1:10.08

Bk 2, p. 71: Unnamed palace scheme, Venice

\begin{abstract}
Doric: façade (bottom)
Ionic : façade (middle)
\end{abstract}

Corinthian: façade (top)

$$
\begin{aligned}
& 2.50 \mathrm{oft}\left(2^{\prime} 6^{\prime \prime}\right) \\
& 2.00 \mathrm{ft}\left(2^{\prime} \mathrm{o}^{\prime \prime}\right)
\end{aligned}
$$$$
1.58 \mathrm{ft}\left(1^{\prime} 7^{\prime \prime}\right)
$$

$20.00 \mathrm{ft}\left(2 \mathrm{o}^{\prime} \mathrm{o}^{\prime \prime}\right)$

$17.00 \mathrm{ft}\left(15^{\prime} \mathrm{o}^{\prime \prime}\right)$

$15.00 \mathrm{ft}\left(15^{\prime} \mathrm{o}^{\prime \prime}\right)$
$1: 8.00$

$1: 8.50$

1:9.49

Bk 2, p. 71: Unnamed palace scheme, Venice

\begin{abstract}
Ionic: façade (bottom)
Ionic : façade (middle)
\end{abstract}

Corinthian: façade (top)
$2.50 \mathrm{ft}\left(2^{\prime} 6^{\prime \prime}\right)$

2.0oft $\left(2^{\prime} \mathrm{o}^{\prime \prime}\right)$

$1.58 \mathrm{ft}\left(1^{\prime} 7^{\prime \prime}\right)$
22.50 ft $\left(22^{\prime} 6^{\prime \prime}\right)$

$19.00 \mathrm{ft}\left(15^{\prime} \mathrm{o}^{\prime \prime}\right)$

$15.00 \mathrm{ft}\left(15^{\prime} \mathrm{o}^{\prime \prime}\right)$

22.50 ft $\left(22^{\prime} 5^{\prime \prime}\right)$

$19.00 \mathrm{ft}$ (19' o")

$2.50 \mathrm{ft}\left(2^{\prime} 6^{\prime \prime}\right)$

$2.50 \mathrm{ft}\left(2^{\prime} 6^{\prime \prime}\right.$ : error)

[2.0oft: presumed]

$32.50 \mathrm{ft}\left(32^{\prime} 6^{\prime \prime}\right)$

$1: 9.00$

$1: 9.50$

$1: 9.49$

1:9.00

1:9.00

[1:9.5o]

1:10.00

$22.50 \mathrm{ft}\left(22^{\prime} 5^{\prime \prime}\right)$

$1: 9.00$

2.5oft ( $\left.2^{\prime} 6^{\prime \prime}\right)$

$20.00 \mathrm{ft}\left(20^{\prime} \mathrm{o}^{\prime \prime}\right)$

1:10.00

$2.00 \mathrm{ft}\left(2^{\prime} \mathrm{o}^{\prime \prime}\right)$

$20.00 \mathrm{ft}\left(20^{\prime} 0^{\prime \prime}\right)$

22.50ft $\left(22^{\prime} 6^{\prime \prime}\right)$

$40.00 \mathrm{ft}\left(16^{\prime} \mathrm{o}^{\prime \prime}\right)$

1:9.00

1:10.00

$19.79 \mathrm{ft}\left(19^{\prime} 9^{1 / 22^{\prime \prime}}\right)$

1:8.04

$1: 8.00$

$1: 7.91$

$1.50 \mathrm{ft}\left(\mathrm{I}^{\prime} 6^{\prime \prime}\right)$

$12.00 \mathrm{ft}\left(12^{\prime} \mathrm{o}^{\prime \prime}\right)$

$1: 9.06$

$1: 7.88$

$1.96 \mathrm{ft}\left(1^{\prime} 11^{1 / 2}{ }^{\prime \prime}\right)$

$17.75 \mathrm{ft}\left(17^{\prime} 9^{\prime \prime}\right)$

1:8.75

$1.25 \mathrm{ft}\left(\mathrm{I}^{\prime} 3^{\prime \prime}\right)$

1:8.20

1:8.03

$10.25 \mathrm{ft}\left(10^{\prime} 3^{\prime \prime}\right)$
$-$

$-$ 


\section{NOTES}

1 Andrea Palladio, I quattro libri dell'architectura (Venice, 1570). For a modern translation equipped with an excellent glossary, see Andrea Palladio, The Four Books on Architecture, ed. Richard Schofield and Robert Tavernor (Cambridge, Mass., 1997). For a rounded discussion of the treatise, see Bruce Boucher, Andrea Palladio: the Architect in His Time (New York, London and Paris, 1993), pp. 231-63. Palladio had already produced some material on the orders for the treatise by the mid-1550s, as Daniele Barbaro records in his Vitruvius edition (as below n.14, ed. 1567, p. 303), although much of the material was prepared after the publication of Vignola's treatise in 1562.

2 Palladio, I quattro libri, Book 1, p. 6 ('... quei precetti, che universali sono ...') and pp. 18-50.

3 Palladio's work is extensively covered in many publications, for which the modern foundations were laid by Giangiorgio Zorzi, Le opere pubbliche e i palazzi privati di Andrea Palladio (Venice, 1965); idem, Le chiese e i ponti di Andrea Palladio (Venice, 1967); and idem, Le ville e i teatri di Andrea Palladio (Venice, 1969). Detailed coverage is provided by Lionello Puppi, with contributions from Donata Battilotti, Andrea Palladio (ed. Milan, 1999). For a brief and up-to-date listing of Palladio's work (supplying the dates used here for his various schemes), see the website of the Palladio Museum in Vicenza: http://mediateca.palladiomuseum.org/palladio/opere.php.

4 Various aspects of the presentation of the orders in the Quattro libri are explored by Hubertus Günther, 'Palladio e gli ordini di colonne', in Andrea Palladio: nuovi contributi, ed. André Chastel and Renato Cevese (Milan, 1990), pp. 182-97; and Branko Mitrović, 'Palladio's Theory of Classical Architecture in the First Book of I quattro libri dell'architettura', Architectural History, 42 (1999), pp. 110-40. These matters will be addressed further in the final section of this article.

5 Aspects of this development are covered e.g. by Pier Nicola Pagliara, 'Vitruvio: da testo a canone', in Memoria dell'antico nell'arte italiana, ed. Salvatore Settis (Turin, 1986), pp.3-85. See also Georgia Clarke, 'Vitruvian Paradigms', Papers of the British School at Rome, 70 (2002), pp. 317-44.

6 Leon Battista Alberti, L'architettura, ed. Cosimo Bartoli (Florence, 1550, and Venice, 1565). For Bartoli's publications of Alberti's treatise, see Judith Bryce, Cosimo Bartoli, 1503-1572; the Career of a Florentine Polymath (Geneva, 1983), pp. 185-92.

7 See Hubertus Günther, 'Serlio e gli ordini architettonici', in Sebastiano Serlio, ed. Christof Thoenes (Milan, 1989), pp. 154-68.

8 See especially Christof Thoenes in Jacopo Barozzi da Vignola, ed. Richard J. Tuttle et al. (Milan, 2002), pp. 333-66.

9 Palladio, I quattro libri, Book 1, p. 15; Book 4, p.64.

10 Ottavio Bertotti Scamozzi, Le fabbriche e i disegni di Andrea Palladio, 4 vols (Vicenza, 1776-83). For Bertotti Scamozzi, see Loredana Olivato, Ottavio Bertotti Scamozzi, studioso di Andrea Palladio (Vicenza, 1975); and Christine Kamm-Kyburz, Der Architekt Ottavio Bertotti Scamozzi 1719-1790: ein Beitrag zum Palladianismus im Veneto (Bern, 1983).

11 Bertotti Scamozzi's measurements are given in the local unit of measure, the Vicenza foot, and their accuracy is attested to, generally, by Deborah Howard and Malcolm Longair, 'Harmonic Proportion and Palladio's Quattro libri', Journal of the Society of Architectural Historians, 41 (1982), pp.116-43 (p.129); and by Mitrovic, 'Palladio's Theory of Classical Architecture', pp. 120-21. It appears the case, too, that the size of Bertotti Scamozzi's foot corresponds closely (despite occasional claims to the contrary) to the usually specified size of the Vicenza foot $(1 \mathrm{ft}=35.7 \mathrm{~cm}$ ); see Angelo Martini, Manuale di metrologia (Turin, 1883), p. 823 . Dimensions for the orders are given infrequently in other surveys, so it is only possible to confirm Bertotti Scamozzi's reliability in a very few instances. Villa Cornaro at Piombino Dese, for example, is the subject of a recent and detailed survey: see Andrea Palladio: Villa Cornaro in Piombino Dese, ed. Branko Mitrović and Stephen R. Wassell (New York, 2006), in particular pp. 26-27, 42 and 46 . This gives the lower Ionic an average diameter of $69.68 \mathrm{~cm}$ and heights of $620.5 \mathrm{~cm}$ (front) and $638.0 \mathrm{~cm}$ (rear), to produce ratios of 1:8.90 and 1:9.16; and the upper Corinthian order an average diameter of $56.53 \mathrm{~cm}$ and heights of $593.0 \mathrm{~cm}$ (front) and $592.5 \mathrm{~cm}$ (rear), to produce ratios of 1:10.49 and 1:10.48. Bertotti Scamozzi gave the lower storey a diameter of $69.9 \mathrm{~cm}(1.96 \mathrm{ft})$ and a height of $632 \mathrm{~cm}(17.71 \mathrm{ft})$, producing a ratio of 1:9.04; and the upper storey a diameter at $57.5 \mathrm{~cm}$ and a height at $593 \mathrm{~cm}$, producing a ratio of 1:10.17. Occasional dimensions for the orders are included on the survey drawings held at the Palladio Museum (and featured on their website; see above n. 3) and, although these are not necessarily more accurate, they further confirm Bertotti Scamozzi's reliability. The few measurements provided, which are for Palazzo Antonini in Udine (Ionic and Corinthian), Palazzo Porta Festa in Vicenza (Ionic), Villa Badoer at Fratta Polesine (Doric and Ionic), Villa Cornaro at Piombino Dese (Ionic) and Villa Thiene at Quinto (Doric), mostly correspond very closely with the figures specified by Bertotti Scamozzi. 
12 Palladio, I quattro libri, Book 1, p. 15; see also ibid., general preface, p. $3\left({ }^{\prime} \ldots\right.$ con le proprie mani [ho] misurato i fragmenti di molti edificij antichi ...'); Book $1, \mathrm{p} .5\left({ }^{\prime} \ldots\right.$ cominciai à misurare minutissimamente con somma diligenza ciascuna parte loro ...'); and Book 4, p.3 ('... sono stati misurati da me con somma consideratione ...').

13 Ibid., Book 1, p. 5 ('... mi proposi per maestro, e guida Vitruvio ...') and 15.

14 Vitruvius, I dieci libri dell'architettura, ed. Daniele Barbaro (Venice, 1556 and 1567); see Louis Cellauro, 'Palladio e le illustrazioni delle edizioni del 1556 e del 1567 di Vitruvio, Saggi e memorie di storia dell'arte, 22 (1998), pp.55-128; idem, 'Daniele Barbaro and his Venetian Editions of Vitruvius of 1556 and 1567', Studi veneziani, 40 (2000), pp. 87-134; and idem, 'Daniele Barbaro and Vitruvius: the Architectural Theory of a Renaissance Humanist and Patron', Papers of the British School at Rome, 72 (2004), pp. 293-329.

15 Vitruvius, De architectura, IV, 7, 2-5.

16 Sebastiano Serlio, Tutte l'opere d'architettura et prospetiva (Venice, 1619), Book 4, ff. 127v-129; Jacopo Barozzi da Vignola, Regola delli cinque ordini d'architettura (Rome, 1562), pl. 4-8; Pietro Cataneo, L'architettura (Venice, 1567), pp.111-13.

17 Vitruvius, I dieci libri, ed. Barbaro (1567), pp. 143 and 196.

18 Serlio, Tutte l'opere, Book 4, f. 128v ('questo sarà quando l'opera si vorrà far più delicata').

19 See e.g. Richard Schofield in Stefano Della Torre and Richard Schofield, Pellegrino Tibaldi architetto e il S. Fedele di Milano (Milan, 1994), pp.69-78.

20 Serlio, Tutte l'opere, Book 3 , ff. $80 \mathrm{v}$ and $82 \mathrm{v}-86$.

21 Palladio, I quattro libri, Book 1, p. 19. Serlio had described their orders as 'Rustic', which for him was closely equivalent to Tuscan; see Serlio, Tutte l'opere, Book 4, f. 126v; cf. Palladio, I quattro libri, Book I, p. 15 (referring to amphitheatres).

22 Palladio, I quattro libri, Book 2, p.60. The proportions of the extant columns are determined from measurements given on survey drawings in the Palladio Museum (see above n. 11) - the heights supplied by Bertotti Scamozzi being for the building's exterior and not the colonnades. The proportions in the Quattro libri illustration are likewise of around 1:7/2 (see Table 4).

23 As n. 19 .

24 The bases of these half-columns have no plinths.

25 Serlio, Tutte l'opere, Book 4, ff. 139-142; Vignola, Regola, pl. 9-14; Cataneo, L'architettura, pp.113-19.

26 Vitruvius, De architectura, IV, 1, 6 and 8; v, 9, 3 .

27 Palladio also cites the Doric 'Temple of Piety' (the southern temple in Rome's Forum Holitorum; see below n. 68) and the ancient theatre in Vicenza: Palladio, I quattro libri, Book 1, p.22. For his own drawing of the Theatre of Marcellus (London, R.I.B.A., Palladio, vol. x, 20), see e.g. Giangiorgio Zorzi, I disegni delle antichità di Andrea Palladio (Venice, 1959), p. 92.

28 Measurements are provided by Antoine Desgodetz, Les Édifices antiques de Rome (Paris, 1682), p. 293. Desgodetz's illustrations of Rome's antiquities are far superior in their accuracy to those in previous publications, including Palladio's Book 4 on temples which is often explicitly criticised.

29 Palladio explains that the bottom part of the shaft can be made from the same piece of stone as the base: I quattro libri, Book 1, p. 22.

30 For Palladio's drawing of various details from the Basilica Aemilia, see e.g. Zorzi, I disegni delle antichità, p. 104; see also at $n .111$ below. The cornice was drawn, previously, in the Codex Coner; see Thomas Ashby, 'Sixteenth-Century Drawings of Roman Buildings Attributed to Andreas Coner, Papers of the British School at Rome, 2 (1904), pp. I-96 (pp. 43-43, no. 77).

31 Serlio, Tutte l'opere, Book 4, f. 139.

32 Palladio specifically mentions the Porta dei Leoni in this context: I quattro libri, Book 1, p. 22. The gate's pedestal is illustrated by Serlio (Tutte l'opere, Book 3, f. 116). The flared plinth is also seen in Palladio's executed schemes (see Fig. 32) but only intermittently.

33 See Serlio, Tutte l'opere, Book $4, \mathrm{ff} .140$ and $141 \mathrm{v}-42$.

34 Vitruvius, De architectura, IV, 3, 9. A local example of such fluting is to be found on the earlier of the two façades of the Porta dei Leoni in Verona (Serlio, Tutte l'opere, Book 4, ff. 116v-17).

35 Vitruvius, De architectura, IV, 3, 4-8.

36 The cornice is represented more exactingly in one of the plates of details (Palladio, I quattro libri, Book 1, p. 27) which also shows the typically Doric ornamentation on the underside of the corona, this being closely based on that from the Theatre of Marcellus which is recorded in the Codex Coner; see Ashby, 'SixteenthCentury Drawings of Roman Buildings', p. 42, no. 76.

37 Palladio, I quattro libri, Book 1, p. 26; Serlio, Tutte l'opere, Book 4, f. 141. 
38 For example, the Doric columns of the 'Temple of Piety' (mentioned by Palladio: see n. 27) have proportions, according to Serlio's measurements, of around 1:7.7 (see Tutte l'opere, Book 3, f.60), while the Doric half-columns of the Colosseum have proportions of around 1:9.5; see Desgodetz, Les Édifices antiques, p. 259 .

39 Serlio, Tutte l'opere, Book 4 , ff. $187-88$.

40 Ibid., Book $4, f_{18} 18$ ('... di far le colonne più gracile [quando] più tosto per ornament, che per sostegno.').

41 See above no. 24 .

42 The deployment of the base is a departure from the Theatre of Marcellus, which served both buildings as a principal prototype, but it is presaged by Sansovino's Library of St Mark's in Venice (1537).

43 See Serlio, Tutte l'opere, Book 3, f.69v; Book 4, f. 140. A minor variation in Palladio's practice, however, is seen in the Doric capitals of the Villa Emo at Fanzolo, which, beneath the echinus, feature a cima recta molding rather than three rings.

44 For detailed discussion of the use of the Doric order in early sixteenth-century architecture, see Christiane Denker Nesselrath, Die Süulenordnungen bei Bramante (Worms, 1990); Hubertus Günther, 'Die Anfänge der modernen Dorica', in L'Emploi des ordres à la Renaissance, ed. Jean Guillaume (Paris, 1992), pp. 97-117.

45 The fluted Doric pilasters on the side elevation of the Loggia del Capitaniato are an exception.

46 See Howard Burns, 'Raffaello e "quell'antiqua architettura"', in Raffaello architetto, ed. Cristoph L. Frommel et al. (Milan, 1984), pp. 381-96 (p. 387). See also below at n. 118 .

$47 \mathrm{lbid}$. The guttae are shown in an early drawing by Giuliano da Sangallo (Codex Barberini, f. 4v).

48 They are once again featured in the vestibule of S. Maria della Carità.

49 For the Colosseum cornice, see Serlio, Tutte l'opere, Book 3, f. 81; Desgodetz, Les Édifices antiques, pp. 261, 265 and 271 ; see also below at $n$. 69. The Palazzo Chiericati cornice has the slab positioned directly underneath the corona, like an ancient cornice illustrated in the Codex Coner; see Ashby, 'Sixteenth-Century Drawings of Roman Buildings', p.41, no. 72 .

50 The decoration is identical to that once ornamenting the frieze of the Mausoleum of Hadrian and recorded in an early sixteenth-century drawing (Florence Uffizi A433ov); see Alfonso Bartoli, I monumenti antichi di Roma nei disegni degli Uffizi di Firenze, 6 vols (Florence, 1914-22), Iv, fig. 621.

51 Why Palladio should have chosen to treat the Doric entablature in this way is not clear; but it may be that the dentils, which are directly beneath the corona, were conceived as being directly analogous to the modillions used for the entablatures of both the Ionic and Corinthian storeys above.

52 Vitruvius, De architectura, IV, 1, 7-8; V, 9, 4 .

53 Serlio, Tutte l'opere, Book 4, ff. 158v-62; Vignola, Regola, pl. 15-20; Cataneo, L'architettura, pp. 120-24.

54 Another general type, with a neck beneath the scrolls, is illustrated by Serlio (Tutte l'opere, Book 4, f. 16ov), and this (discussed in more detail below) was very popular in early sixteenth-century practice.

55 Palladio, I quattro libri, Book 4, pp. 50-51; Serlio, Tutte l'opere, Book 4, ff. 159-160.

56 Palladio, I quattro libri, Book 4, Pp.50-51; The subsequent illustration of Desgodetz (Les Édifices antiques, p.102) shows that the capitals are actually decorated rather more simply.

57 Palladio, I quattro libri, Book 1, pp.31 and 34; Vitruvius, De architectura, III, 5, 3.

58 Serlio, Tutte l'opere, Book 4, f. 161v; Vitruvius, I dieci libri, ed. Barbaro (1567), p. 154. Vitruvius, on two occasions, refers to the Ionic order as the 'pulvinate': De architectura, I, 2, 4 and IV, 1, 12.

59 Vitruvius, De architectura, III, 5, 11; Vitruvius, I dieci libri, ed. Barbaro (1567), p. 154.

60 An exception is the Temple of Saturn, as mentioned below.

61 Serlio, Tutte l'opere, Book 4, f. 170 and Book 3, f. 54 and 112. This principle was informed by a comparable pronouncement made by Vitruvius concerning the combination of dentils with mutules for the Doric order: Vitruvius, De architectura, IV 2,-5. For further analysis, see Mitrović, 'Palladio's Theory of Classical Architecture', pp.116-19.

62 Palladio, I quattro libri, Book 4, pp. 78 and 127.

63 Villa Chiericati at Vancimuglio (c.1555) has very slender Ionic columns which may be a product of its protracted building history. Villa Valmarana at Lisiera (c.1563) has unusually squat Ionic columns that may well be a consequence of the abandonment of building work mid-way through construction.

64 Serlio illustrates this kind of capital in a diagram that appears to be based on the Temple of Portumnus (Tutte l'opere, Book 4, f.160v), although he does not actually name it, and he discusses it specifically in connection with the designing of cloisters and courtyards.

65 This type is found in the Lateran Baptistery, although it is not the capital specimen shown in the Quattro libri illustration (Book 4, p.63). The more unusual Ionic capitals of the Temple of Saturn likewise have volutes at the four corners (ibid., Book 4, p.127). 
66 See below at $n .76$.

67 The matter is discussed in more detail at $\mathrm{n} .117$ below.

68 The colonnade is that of a once-neighbouring temple, the northern temple of the Forum Holitorum, and the blocks are the ends of lintels covering the passageway between the columns and the cella. The temple was closely studied by Antonio da Sangallo and his entourage, and is reconstructed by his associate Antonio Labacco: see Antonio Labacco, Libro appartenente a l'architettura (Rome, 1558), pp. 23-24. See also e.g. Ian Campbell, Ancient Roman Topography and Architecture: The Paper Museum of Cassiano dal Pozzo, Part A9, 3 vols (London, 2004), I, pp. 120-35 and 138-41.

69 Palladio, I quattro libri, Book 4, Pp. 80 and 83-84; seen also at the Temple of the Sibyl at Tivoli (ibid. p.93) and the Temple of Antoninus and Faustina (ibid. p. 35), where the moulding is described (ibid. p.30) as a 'dentello non intagliato'. Serlio, with reference to the interior of the Pantheon, similarly describes the moulding as a having 'the form of a row of dentils' ('la forma del dentello') but not being carved as such; Serlio, Tutte l'opere, Book 3, f.54. Similar ledges are to be seen in the entablatures of other ancient buildings, including the Colosseum (see above n. 49) and the Arch of the Silversmiths (see Desgodetz, Les Édifices antiques, p. 221).

70 Vitruvius established implicit proportions for the Corinthian column of $1: 9^{2 / 3}$ by specifying that it should have the same proportions as the Ionic (1:9), but with a capital height equal to the column diameter rather than a third of the size; see Vitruvius, De architectura, IV, I, 1 .

71 Palladio's measurements are sometimes approximated, but they are broadly in line with those determined in Desgodetz, Les Édifices antiques.

72 Serlio, Tutte l'opere, Book 4, ff. 169-71; Vignola, Regola, pl. 21-27; Cataneo, L'architettura, pp. 126-29.

73 Palladio, I quattro libri, Book 4, p. 67: the capitals have tendrils at their centres which are intertwined. For Baldassare Peruzzi's similar praise for these capitals, see Georgia Clarke, "La più bella e meglio lavorata opera": Beauty and Good Design in Italian Renaissance Architecture', in Concepts of Beauty in Renaissance Art, ed. Francis Ames Lewis and Mary Rogers (Aldershot, 1998), pp. 107-23 (pp. 110-11).

74 Vignola, Regola, pl. 26.

75 Palladio, I quattro libri, Book 4, p. 23 ('Le lingue del capitello sono intagliate à foglie di olivo, e sono queste foglie ordinate à cinque, à cinque; come sono le dita nelle mani degli huomini ...') and p. 28 . The foliage is unlike that in the example illustrated by Serlio (Tutte l'opere, Book 4, f. 171), but it is of a kind seen in several of Palladio's early drawings of Corinthian capitals, including those of the Temple of Minerva (Vicenza, Palladio Museum, $\mathrm{D}_{7}$ and $\left.30 \mathrm{v}\right)$; see Zorzi, I disegni delle antichità, pp. 74-75.

76 Palladio, I quattro libri, Book 4, p.6o. Similar bases are also seen at the Basilica of Maxentius (ibid., p. 14) and the Temple of Serapis (ibid., p.47).

77 The type was drawn by Giuliano da Sangallo (Codex Barberini, f. 15).

78 Serlio, Tutte l'opere, Book 4, f. 170.

79 See Palladio, I quattro libri, Book 4, pp. 80 and 83.

80 See below n. 147 .

81 Palladio, I quattro libri, Book 4, p. 29.

82 Bertotti Scamozzi, Le fabbriche e $i$ disegni, vol. 1, p. 70: 'questi pilastri sono più alti di 9 diametri e mezzo'; the height is given but, frustratingly, not the width.

83 The capitals often accord with the treatise in having 'olive leaf' foliage, although the capital foliage seen on the Palazzo Valmarana façade is more like standard acanthus.

84 The Corinthian capitals of Palladio's S. Francesco della Vigna façade are notably schematic.

85 Desgodetz, Les Édifices antiques, p. 271.

86 The plinth in these cases is given a correspondingly greater height. For the portal of the Redentore, the bases are more elaborate and are of the attic type with two extra astragals.

87 Palladio, I quattro libri, Book 4, p. 69.

88 Exceptions include the fluted columns positioned around the high altar of S. Giorgio Maggiore, the fluted pilasters on the upper-storey of the façade of the Casa Cogollo in Vicenza (1559), and those of the interior window tabernacles of the Redentore.

89 Palladio, I quattro libri, Book 4, p. 67 and pp. 63 and 87.

90 Ibid., p. 67 and also p. 47 for the Temple of Serapis which has similar double-tier modillions.

91 According to the measurements supplied by Desgodetz, however, the Composite order of the Arch of Septimius Severus has proportions of 1:10, and that of the Arch of Titus has proportions of around 1:101/2; Desgodetz, Les Édifices antiques, pp. 188-89 and 178-79.

92 Serlio, Tutte l'opere, Book 4, ff. 183-85; Vignola, Regola, pl. 28 and 31; Cataneo, L'architettura, pp. 129-30.

93 See Desgodetz, Les Édifices antiques, p. 207. 
94 For example, the capitals of the Lateran Baptistery and S. Costanza; see Palladio, I quattro libri, Book 4, pp. 63 and 87.

95 Serlio, Tutte l'opere, Book 4, f. $183 \mathrm{v}$.

96 Palladio, I quattro libri, Book 4, p.63. The unusual bases featured in the illustration provided models, as Palladio noted (ibid., p.61), for those of the columns on the rear face of the S. Giorgio façade.

97 Ibid., Book 4, p. 67.

$98 \mathrm{Ibid}$., Book 4, p.63. The Corinthian capitals of the third and fourth storeys of the Colosseum also have uncarved foliage.

99 The type was employed previously by Raphael for the Ionic order on the exterior of Villa Madama (for which see below at n. 106). It is also similar to the bases of the Maison Carée at Nîmes (ibid., Book 4, p.115), except that these have a lower pair of astragals and then two single astragals above.

Ioo Ibid., Book 4, p. 122.

101 This is exceptional in Palladio's practice; an ancient prototype is provided by the Temple of Augustus and Rome in Pula; ibid., Book 4, p. 109.

102 For the pulvinated frieze, see above n. 58.

103 See Zorzi, I disegni delle antichità, pp. 17-23.

104 For Bramante, see in particular Denker Nesselrath, Die Säulenordnungen bei Bramante; and eadem, 'Bramante e l'ordine corinzio', in L'Emploi des ordres, ed. Guillaume, pp.83-96. For Raphael, see Burns, 'Raffaello e "quell'antiqua architettura"', pp.389-90; and Christoph Luitpold Frommel, 'Raffaello e gli ordini architettonici', in $L^{\prime}$ Emploi des ordres, ed. Guillaume, pp. 119-36.

105 Palladio, I quattro libri, Book 4, pp.64-66.

106 For discussion of likely theoretical principles underlying Raphael's practice see David Hemsoll, 'Raphael's New Architectural Agenda', in Imitation, Representation and Printing in the Italian Renaissance, ed. Roy Eriksen and Magne Malmanger (Pisa and Rome, 2009), pp. 201-39. For the Ionic order of the Villa Madama, see Burns, 'Raffaello e "quell'antiqua architettura"', p. 389; Frommel, 'Raffaello e gli ordini architettonici', p. 124; Hemsoll, 'Raphael's New Architectural Agenda', pp. 216-18.

107 It may thus be highly significant that the design of the ciborium in the hospital attached to Sangallo's church of S. Spirito in Sassia is attributed by long tradition to Palladio; see, for example, Puppi with Battilotti, Andrea Palladio, p. 266. This could well suggest some direct involvement with the Sangallo workshop.

108 See the original dedication to Book 4: Sebastiano Serlio, Sebastiano Serlio on Architecture, ed. Vaughan Hart and Peter Hicks, 2 vols, (New Haven and London, 1996 and 2001), I, p. 251. Palladio himself acknowledged a debt to Sangallo but only in the company of other illustrious architects of the period: I quattro libri, Book 4, p.64.

109 See David Hemsoll, 'Palladio e il tempio antico autentico nelle illustrazioni dei Quattro libri', in Palladio 1508-2008: il simposio del cinquecentenario, ed. Franco Barbieri et al. (Venice, 2008), pp. 144-49.

110 See above n. 12 .

11 I Uffizi A1413 (Sangallo); Bartoli, I monumenti antichi, vol. 3, figs 391-92. Uffizi A1057 (G.B. da Sangallo); ibid., vol. 4, fig. 533 .

112 Vicenza, Palladio Museum, D 6v (Palladio); Zorzi, I disegni delle antichità, p. 76. Uffizi A118o (Sangallo); Bartoli, I monumenti antichi, vol. 3, fig. 357. Uffizi A1407 (now attributed to Pietro Rosselli); ibid., vol. 1, fig. 155.

113 For Sangallo's usage of the orders (and his dependency on Bramante and Raphael), see Pier Nicola Pagliara, 'Antonio da Sangallo il Giovane e gli ordini', in L'Emploi des ordres, ed. Guillaume, pp. 137-56. Several of Sangallo's schemes are illustrated in dimensioned engravings in Paul Marie Letarouilly, Édifices de Rome moderne (Paris, 1840-57).

114 Pagliara, 'Antonio da Sangallo e gli ordini', pp. 144-45.

115 See the example in the Cappella Setta of S. Giacomo degli Spagnoli (c.1520); ibid., p. 156, ill. 20.

116 See ibid., p. 156, ills 18 and 19.

117 See ibid., p. 145. See also Howard Burns, 'Baldassare Peruzzi and Sixteenth-Century Architectural Theory', in Les Traités d'architecture de la Renaissance, ed. Jean Guillaume (Paris, 1988), pp. 207-26 (pp. 216-17); and Frédérique Lemerle and Yves Pauwels, 'L' Ionique: un ordre en quête de base', Annali di architettura, 3 (1991), pp.7-13. The antique example recorded by Sangallo and drawn attention to here (Uffizi A1182; Bartoli, I monumenti antichi, vol. 3, fig. 353) is slightly different in that it has three pairs of astragals rather than two. There is, however, a drawing by Sangallo (Uffizi A1174; ibid., vol. 3, fig. 472) showing a base of identical type to that used for Palazzo Farnese, which is on a sheet concerned with the Doric and Ionic temples of the Forum Holitorum (cf.n.68). 
118 The friezeless Doric entablature (cf.n.46) had been revived by Raphael for his Palazzo Branconio dell'Aquila (Burns, 'Raffaello e "quell'antiqua architettura"', p. 387), and was also employed subsequently for the interior of Sanmicheli's Porta Nuova. The capitals in the Palazzo Farnese vestibule are of the same type, with an S-profiled echinus, that Palladio used for the interior of the Loggia del Capitaniato.

119 Pagliara, 'Antonio da Sangallo il Giovane e gli ordini', pp. 145 and 148.

120 Uffizi A826v; see Paola Zampa, 'Dall'astrazione alla regola', Bolletino d'Arte, 46 (1987), pp.49-62; Pagliara, 'Antonio da Sangallo il Giovane e gli ordini', pp. 143 and 147.

121 See above at $n .106$.

122 For a comparable arrangement in a drawing by Antonio for St Peter's (Florence, Uffizi 64A) see Christof Thoenes in The Architectural Drawings of Antonio da Sangallo and His Circle; vol. 2: Churches, Villas, the Pantheon, Tombs, and Ancient Inscriptions, ed. Christoph L. Frommel and Nicholas Adams (Cambridge Ma. and London, 2000), pp. 86-87. Sangallo also coupled tall and small orders in his façade scheme for S. Marco in Florence (Uffizi 1363Av), where the respective bases are juxtaposed very neatly; see Manfredo Tafuri in ibid., p. 242.

123 See Pagliara, 'Antonio da Sangallo il Giovane e gli ordini', p. 149.

124 Palladio, I quattro libri, Book 1, p. 5.

125 Giorgio Vasari, Le vite dei più eccellenti pittori, scutori ed architettori, ed. Gaetano Milanesi, 9 vols (Florence, 1878-85), V, p.324: contrasting Falconetto as well as Fra Giocondo and Sanmcheli with those previously who wished 'né misura né proporzione di colonna, né di ordine alcuno'.

126 For Falconetto's orders, see the scaled drawings of his works appended to Alvise Cornaro e il suo tempo, ed. Lionello Puppi and Giuseppe Barbieri (Padua, 1980).

127 This feature is also seen in certain other schemes from before Palladio's time, including the Corinthian portal (1531) of S. Maria dei Servi in Vicenza and the Villa Trissino at Cricoli (1534). It is also seen in even earlier works such as the interior (design established c.1509) of S. Salvatore in Venice.

128 See Paul Davies and David Hemsoll, Michele Sanmicheli (Milan, 2004), pp. 338-41.

129 Ibid., pp. 114-25 and 368. Sanmicheli used a similar Tuscan order for the exterior of his Madonna di Campagna (1559; mostly completed by 1587); ibid., pp. $128-43$ and 376. For Sanmicheli's Tuscan order in general, see ibid., pp.328-29.

130 Ibid., pp. 243-52 and 358-59.

131 Ibid., pp.327-32. For Sanmicheli's orders, see also Pier Nicola Pagliara, 'Sanmicheli e gli ordini', in Michele Sanmicheli: architettura, linguaggio e cultura artistica nel Cinquecento, ed. Howard Burns et al. (Milan, 1995), pp. 145-53. For another aspect of Sanmicheli's approach towards the orders that is reflected in Palladio's practice, see Paul Davies and David Hemsoll, 'Entasis and Diminution in the Design of Renaissance Pilasters', in L'Emploi des ordres, ed. Guillaume, pp. 339-53.

132 The proportions of the orders are listed in the catalogue of Davies and Hemsoll, Michele Sanmicheli (pp. 352-76) and they are gleaned mostly from the very precisely measured engravings found in Francesco Ronzani and Girolamo Luciolli, Le fabbriche civili, ecclesiastiche e militari di Michele Sanmicheli (Verona, 1823).

133 For Sanmicheli's use of the 'Vitruvian' Ionic base, see Davies and Hemsoll, Michele Sanmicheli, p. 308; and for examples by other architects see Lemerle and Pauwels, ' $L$ ' Ionique: un ordre en quete de base', and, in particular, Schofield in Della Torre and Schofield, Pellegrino Tibaldi architetto, pp. 86-87.

134 The combination of dentils and modillions, although decried by Serlio (see above n. 61), finds an ancient precedent in Verona's Arco dei Gavi; see Serlio, Tutte l'opere, Book 3, ff. 112v-113.

135 See above n. 122.

136 As represented by, say, the columns of Villa Sarego, or the unexecuted project for the courtyard of Palazzo Porta Festa (Palladio, I quattro libri, Book 2, pp. 8-10). The origins of Palladio's 'parastatic' pilasters can be traced to Vitruvius's description of his own scheme for a basilica at Fano (Vitruvius, De architectura, V, 1, 610), where the word parastatica would seem likewise to refer to a pilaster attached to a much larger column. For the basilica at Fano, see Sabine Weyrauch, Die Basilika des Vitruv (Tübingen, 1976), pp. 104-25 and 161-64; Paolo Clini, 'Vitruvio e la basilica di Fano: fonti, disegni, influenze', in Vitruvio e il disegno di architettura, ed. Paolo Clini (Venice, 2012), pp. 85-106.

137 The type was, admittedly, featured by Serlio (see above), and is also seen previously, for example, in the courtyard of Baldassare Peruzzi's Palazzo Massimo (1532), and in Giulio Romano's fresco of the Baptism of Constantine (Rome, Vatican; c.1520); illustrated in e.g. Ernst H. Gombrich et al., Giulio Romano (Milan, 1989), p. 226.

138 Other types of Composite capital had recently been used for example by Sanmcheli; see Davies and Hemsoll, Michele Sanmicheli, pp. 330-31. 
139 See Yves Pauwels, 'Les Origines de l'ordre composite', Annali di architettura, 1 (1989), pp. 29-46 (p. 37); Pagliara, 'Antonio da Sangallo il Giovane e gli ordini', pp. 147-48. Sangallo's tombs of Leo X and Clemant VII (c. 1535) in S. Maria sopra Minerva, however, have Composite orders that are much more distinctive, such as in having pulvinated friezes; see also n. 146.

140 See Davies and Hemsoll, Michele Sanmicheli, p. 328.

141 See e.g. Günther, 'Serlio e gli ordini architettonici', p. 166. Nor does Vignola include the Composite in his main sequences of plates (see Fig. 28).

142 Vincenzo Scamozzi, L'idea della architettura universale (Venice, 1615), Part 2, p. 6 (showing columns); in the other main illustration (Pp. 34-35: showing arcades and attached half-columns), the proportions are reversed.

143 Günther, 'Serlio e gli ordini architettonici', pp. 161-66.

144 Porta Savonarola has 'Pantheon' bases whereas Porta S. Giovanni has simpler Attic bases.

145 See Bertrand Jestaz, 'L'Apparation de l'ordre composite à Venise', in L'Emploi des ordres, ed. Guillaume, pp. $157-68$.

146 See also Pauwels, 'Les Origines de l'ordre composite', pp. 37-38, who discusses Baldassare Peruzzi's tomb of pope Adrian VI (1523) in S. Maria dell'Anima which has a Composite order and a pulvinated frieze (associated by theorists with the Ionic order), and which is, therefore, like Sansovino's Loggetta.

147 See, for example, Andrea Palladio, I quattro libri dell'architectura, ed. Licisco Magagnato and Paola Marini (Milan, 1980), p.422; and Christof Thoenes in Jacopo Barozzi da Vignola, ed. Tuttle et al., pp. 206-o9. Two of the plates of details, of the Doric order (I quattro libri, Book 1, p.27) and the Corinthian order (ibid., p.43), are remarkably similar, the last discussed extensively in Mitrović, 'Palladio's Theory of Classical Architecture', pp.121-25.

148 Mitrović draws attention to many striking similarities between the descriptions, in the Quattro libri and the Barbaro Vitruvius, of the Tuscan, Doric and Ionic orders; Mitrović, 'Palladio's Theory of Classical Architecture', pp.113-19.

149 See at n. 147 .

150 Such as giving extra mouldings to the entablature of the Doric order, or modillions but not dentils to that of the Ionic order.

151 See above at n. 32 .

152 See n. 147.

153 Palladio includes many such measurements on his Quattro libri plates (some deciphered only with difficulty), and these are specified in Vicentine feet and inches, and very occasionally 'minutes' ( $\mathrm{I}$ inch $=4$ 'minutes'), as he describes and illustrates (I quattro libri, Book 2, p.4). His illustration (if accurate) implies that his foot measures around $35.0 \mathrm{~cm}$, which is close to the official foot of the day of $35.4 \mathrm{~cm}$ (as incised in a stone standard of 1583); see e.g. Andrea Palladio: Villa Cornaro, ed. Mitrović and Wassell, pp.41-42. It is rather shorter, however, than the Vicentine foot in use subsequently, which measures $35.7 \mathrm{~cm}$ (see $\mathrm{n} .11$ ).

154 Palladio, I quattro libri, Book 2, p.64.

155 Ibid., Book 3, p. 43; Book 2, pp. 51 and 66-67.

156 Ibid., Book 2, pp. 60 and 77.

157 The Corinthian order is also given proportions of 1:10 in Palladio's reconstructions of the four-column atrium (ibid., Book 2, pp. 27-28) and the forum of the Greeks (ibid., Book 3, pp. 32-34).

158 Ibid., Book 2, pp.6-7; Book 3, p. 43 .

159 Ibid., Book 2, p. 32.

161 Ibid., Book 2, p.9.

162 See especially Günther, 'Palladio e gli ordini di colonne'.

163 See Serlio, Tutte l'opere, Book 4, f. 127; and Thoenes in Jacopo Barozzi da Vignola, ed. Tuttle et al., p. 207

164 As pointed out to me by Paul Davies.

165 See Günther, 'Palladio e gli ordini di colonne', pp. 185-95.

166 Palladio, I quattro libri, Book 1, pp. 15-16; Vitruvius, De architectura, III, 3, 1-11.

167 See e.g. Hanno-Walter Kruft, A History of Architectural Theory from Vitruvius to the Present (London and New York, 1994), p.89. 